UNIVERSIDADE FEDERAL DE JUIZ DE FORA CAMPUS AVANÇADO DE GOVERNADOR VALADARES INSTITUTO DE CIÊNCIAS DA VIDA - ICV MESTRADO PROFISSIONAL EM ENSINO DE BIOLOGIA

RAFAELA XAVIER RODRIGUES

HORTAS NO ENSINO DE BIOLOGIA: POSSIBILIDADES, LIMITAÇÕES E SUGESTÕES.

GOVERNADOR VALADARES - MG 
RAFAELA XAVIER RODRIGUES

\title{
HORTAS NO ENSINO DE BIOLOGIA: POSSIBILIDADES, LIMITAÇÕES E SUGESTÕES.
}

\begin{abstract}
Dissertação apresentada ao PROGRAMA NACIONAL DE MESTRADO PROFISSIONAL EM ENSINO DE BIOLOGIA (PROFBIO) da Universidade Federal de Juiz de Fora (UFJF - Instituição Associada), campus avançado de Governador Valadares, e da Universidade Federal de Minas Gerais (UFMG - Instituição sede) como requisito parcial à obtenção do título de Mestre em Ensino de Biologia. Área de concentração Ensino de Biologia pertencente ao macroprojeto "Aprendendo Biologia por meio de questões socioambientais e culturais".
\end{abstract}

Orientadora: Professora Doutora Ione Maria de Matos

GOVERNADOR VALADARES - MG

2021 
Ficha catalográfica da dissertação

Rodrigues, Rafaela Xavier.

Hortas no Ensino de Biologia: possibilidades, limitaçōes e sugestōes. / Rafaela Xavier Rodrigues. - 2021.

$115 \mathrm{f}$.

Orientadora: lone Maria de Matos

Dissertaçăo (mestrado profissional) - Universidade Federal de Juiz de Fora, Campus Avançado de Governador Valadares, Instituto de Ciências da Vida - ICV. Programa de Pós-Graduação em Ensino de Biologia em Rede Nacional, 2021.

1. Hortas no Ensino de Biologia. 2. Hortas no Ensino Médio. 3. Hortas na escola. I. Matos, Ione Maria de, orient. II. Titulo. 


\title{
RAFAELA XAVIER RODRIGUES
}

\section{HORTAS NO ENSINO DE BIOLOGIA: POSSIBILIDADES, LIMITAÇÕES E SUGESTÕES.}

\begin{abstract}
Dissertação apresentada ao PROGRAMA NACIONAL DE MESTRADO PROFISSIONAL EM ENSINO DE BIOLOGIA (PROFBIO) da Universidade Federal de Juiz de Fora - Campus avançado de Governador Valadares.
\end{abstract}

Aprovada em 21 de maio de 2021

\author{
BANCA EXAMINADORA \\ Joue Mana de Matos
}

Doutora lone Maria de Matos - Orientadora

Universidade Federal de Juiz de Fora - Campus Governador Valadares

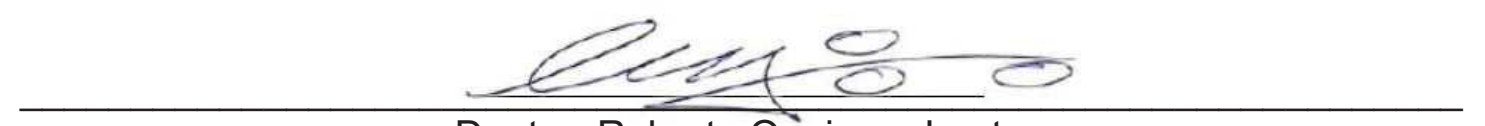

Doutor Roberto Queiroga Lautner

Universidade Federal de Juiz de Fora - Campus Governador Valadares

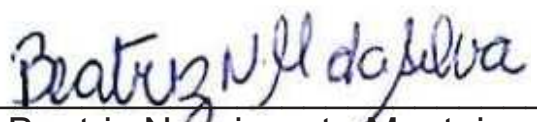

Doutora Beatriz Nascimento Monteiro da Silva Instituto Nacional de Câncer - INCA 
Dedico este trabalho primeiramente a Deus por ter me dado esta oportunidade e à minha filha Bianca. 


\section{AGRADECIMENTOS}

A Deus, por todas as portas abertas e por ter me guiado até aqui.

A minha família por todo apoio e incentivo, em especial a minha filha Bianca, cuja atenção e presença durante a realização deste mestrado foram limitadas e aos meus pais, principalmente a minha mãe Elessandra que sempre me incentivou a estudar.

Aos queridos colegas da $2^{\mathrm{a}}$ turma do PROFBIO, UFJF/GV, junto dos quais construí grandes aprendizados, em especial ao meu amigo Fred, por todo incentivo e parceria nesta caminhada e a Françoes por todo apoio.

Aos meus amigos Welton e Fernando por todas as caronas até GV, e que com certeza contribuíram para tornar as sextas-feiras mais alegres.

Agradeço ao meu companheiro Fabrício por toda compreensão, por me apoiar em momento difíceis e por suportar minhas crises de ansiedade e estresse.

Aos meus colegas de trabalho por toda compreensão e ajuda com horários durante a realização deste curso.

Agradeço imensamente a minha orientadora Ione Maria de Matos, que aceitou me orientar no último momento, e sem a qual, a conclusão deste trabalho não seria possível. A ela minhas eternas considerações!

Agradeço aos professores Maria Gabriela e Thiago Martins pelas riquíssimas contribuições que foram acrescentadas a este trabalho.

O presente trabalho foi realizado com o apoio da Coordenação de Aperfeiçoamento de Pessoal de Nível Superior - Brasil (CAPES) - Código de Financiamento 001. 


\section{RELATO DO MESTRANDO}

\begin{tabular}{|l|}
\hline Instituição: UNIVERSIDADE FEDERAL DE JUIZ DE FORA \\
\hline Mestranda: RAFAELA XAVIER RODRIGUES \\
\hline $\begin{array}{l}\text { Título do TCM: HORTAS NO ENSINO DE BIOLOGIA: POSSIBILIDADES, } \\
\text { LIMITAÇÕES E SUGESTÕES. }\end{array}$ \\
\hline
\end{tabular}

Data da defesa: 21 de maio de 2021

Nasci em Resplendor e durante toda minha infância e adolescência, residi junto com meus pais e irmãos, em um sítio na zona rural, chamado Córrego da Oncinha, meus pais são trabalhadores rurais e desde muito nova aprendi a valorizar o trabalho do homem do campo, um trabalho árduo, que exige muito esforço e dedicação, mas que em contrapartida nos permite estar sempre em contato com a natureza. Neste contexto, minha mãe Elessandra sempre me incentivou a estudar, pois ela via na educação uma oportunidade de alçar novos voos e de ser independente financeiramente. Conclui o ensino fundamental e médio na rede pública de ensino, como morava na zona rural fazia uso de transporte escolar, foram longos 12 anos de idas e vindas a Resplendor, vivenciando muitas aventuras. Sempre fui uma aluna exemplar, mas sempre tive muita vergonha em fazer perguntas aos professores, portanto era sempre calada mas tirava boas notas. No ensino médio as aulas de Biologia me despertavam um grande interesse, e sempre admirei a professora de Biologia, Sandra Benicá, por todo seu conhecimento. Aos 16 anos concluí o terceiro ano do Ensino Médio, e naquele ano me dediquei muito aos estudos para que tivesse bons resultados no ENEM, pois era uma das únicas oportunidades que me permitia realizar uma graduação, e os resultados vieram, devido a boa pontuação, consegui uma bolsa de estudos através do PROUNI e iniciei o curso de Licenciatura Plena em Ciências Biológicas em uma cidade vizinha e desde o primeiro dia do curso, devido a influência da minha professora de Biologia do Ensino Médio, sempre manifestei o desejo em ser professora. Logo que me formei, passado um ano consegui ingressar no magistério lecionando a disciplina de Biologia e Ciências, no entanto ainda não fui nomeada em concurso público e vivo o dilema de professores designados, sempre tenho que deslocar grandes percursos para trabalhar e todo ano trabalho em uma 
escola diferente, o que permite experiências diversas mas impede de dar continuidade a um trabalho na escola além de gerar grande desgaste físico e emocional. Mas neste embalo, já se foram sete anos de experiência nesta área. Sempre estou pesquisando sobre cursos oferecidos de forma gratuita e por instituições federais através de buscas na internet, inclusive já realizei alguns cursos, pois penso que devemos nos atualizar sempre e também incrementar o currículo. Quando vi o edital de seleção do PROFBIO com vagas para Governador Valadares, vi uma grande oportunidade de avançar na carreira acadêmica, no entanto, o primeiro edital do PROFBIO com vagas para Governador Valadares não contemplava o ingresso de professores designados, mas na expectativa de ser nomeada pela Secretaria do Estado da Educação de Minas Gerais, realizei a prova mesmo assim, no entanto fui aprovada fora do número de vagas e não ocorreu a tão sonhada nomeação. No ano seguinte, o edital do PROFBIO contemplava o ingresso de professores em regime de contrato temporário, novamente, fiz minha inscrição e realizei a prova, fiquei aguardando ansiosa pelos resultados, e vibrei quando vi meu nome da lista de aprovados dentro do quadro de vagas, sabia que não seria fácil concluir o mestrado, conciliar trabalho, família, afazeres domésticos e estudos, não é uma tarefa muito fácil, mas jamais teria outra oportunidade como esta. Foram dois anos de muitos aprendizados junto a equipe doscente e discente do PROFBIO, as metodologias apontadas nas aulas ofertadas pelo programa, nos instigaram a refletir sobre nossas práticas doscentes e a desenvolver novas metodologias no Ensino de Biologia. Sou grata pela oportunidade de ter feito parte deste programa que com certeza mudou minha forma de pensar e de ensinar Biologia. 


\section{RESUMO}

O uso de hortas escolares como ferramenta pedagógica de ensino, além de abordar temas relacionados a educação ambiental e a educação para a saúde, apresentam-se como um laboratório vivo de experiências que permitem associar teoria e prática. Neste sentido, o objetivo geral deste trabalho foi realizar uma revisão integrativa sobre as possibilidades e limitações do uso de hortas no ensino de biologia e elaborar sugestões de metodologias ligadas a práticas com hortas escolares para estudantes do ensino médio. Foram analisados estudos publicados originalmente na língua portuguesa, entre os anos de 2010 a 2019, tendo como referência as bases de dados Portal de Periódicos da CAPES e Google Acadêmico. Fizeram parte do escopo desta revisão 32 estudos que preencheram os critérios de seleção. Utilizamos neste estudo uma abordagem qualitativa com objetivo exploratório e descritivo com procedimentos técnicos de pesquisa bibliográfica. Os estudos permitiram concluir que as hortas escolares podem ser utilizadas como ferramentas de ensino de Biologia e além de favorecerem a interdisciplinaridade, também permitem o estudo de temas transversais relacionados a Educação Ambiental, bem como, ampliam a atuação do professor para além da sala de aula.

Palavras-chave: Horta na escola; Horta e ensino médio; Hortas no Ensino de Biologia; Hortas e Educação Ambiental. 


\begin{abstract}
Vegetable gardens could be interesting pedagogical tool in high school, because are a living laboratory for the students and a community. In addition, allow to create a bridge between theory and practice. For this reason, this study aimed to do a integrative review about the possibilities and limitations of the use of vegetable gardens in biological classes and to suggest working approaches that could be used as models for biological practical lessons in high school. In this work, papers published in portuguese from 2010 to 2019 were analyzed using "Periódicos CAPES" and Google Scholar. A total of 32 papers were examined and met the required standard. In this study, we used a qualitative approach with an exploratory and descriptive objective with technical procedures for bibliographic research. As a conclusion, vegetable gardens may be used in biological classes exploring ways to integrate interdisciplinary aspects in the classroom, for example, social and environmental sustainability. Also, may expand the capacity of teacher beyond classroom.
\end{abstract}

Keywords: vegetable garden; high school; biology; environmental education. 


\section{LISTA DE ABREVIATURAS E SIGLAS}

ANVISA Agência Nacional de Vigilância Sanitária

ABRASCO Associação Brasileira de Saúde Coletiva

BNCC Base Nacional Curricular Comum

CEM Centro de Ensino Médio

DCNEA Diretrizes Curriculares Nacionais para a Educação Ambiental

EA Educação Ambiental

EAN Educação Ambiental e Nutricional

EFAGO Escola Família Agrícola de Goiás

EnCI Ensino de Ciências por investigação

EPI Equipamento de Proteção Individual

FIOCRUZ Fundação Oswaldo Cruz

FAO Organização das Nações Unidas para a Alimentação e a Agricultura

IARC Agência Internacional de Pesquisa em Cãncer

IBAMA Instituto Brasileiro do Meio Ambiente e Recursos Naturais

INCA Instituto Nacional do Câncer

OMS Organização Mundial da Saúde

PCN Parâmetros Curriculares Nacionais

PIBID Programa Institucional de Bolsas de Iniciação à Docência

PNDA Plano Nacional de Defensivos Agrícolas

PNEA Política Nacional de Educação Ambiental

PROEX Pró-reitoria de extensão 
SINAN Sistema de Informação de Agravos de Notificação

SINITOX Sistema Nacional de Informações Tóxico-Farmacológicas

SISAGUA Sistema de Informação de Vigilância da Qualidade da Água para Consumo Humano

UFMT Universidade Federal do Mato Grosso

UERGS Universidade Estadual do Rio Grande do Sul 


\section{SUMÁRIO}

Pág.

$1 \quad$ INTRODUÇÃ

2 REFERENCIAL TEÓRICO_................................................................... 17

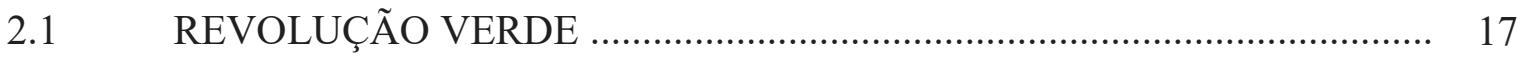

2.2 AGROTÓXICOS, SER HUMANO E MEIO AMBIENTE …...................... 18

2.2.1 AGROTÓXICOS E SEUS EFEITOS SOBRE O SER HUMANO ............... 21

2.2.2 AGROTÓXICOS E SAÚDE HUMANA ….......................................... 22

2.2.3 AGROTÓXICOS E IMPACTOS AMBIENTAIS ................................... 24

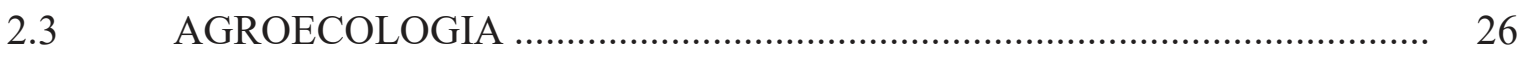

2.4 EDUCAÇÃO AMBIENTAL NAS ESCOLAS …..................................... 27

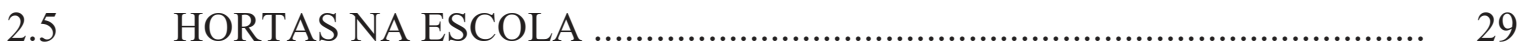

2.5.1 HORTAS NO ENSINO DE BIOLOGIA............................................... 31

2.6 ENSINO DE BIOLOGIA POR INVESTIGAÇÃO .................................... 33

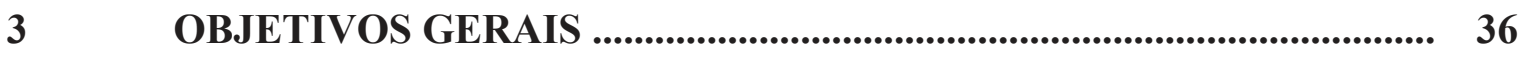

OBJETIVOS ESPECÍFICOS …...................................................... 36

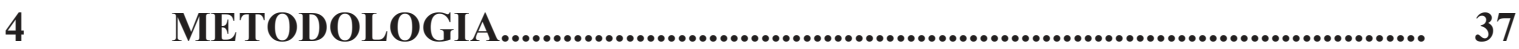

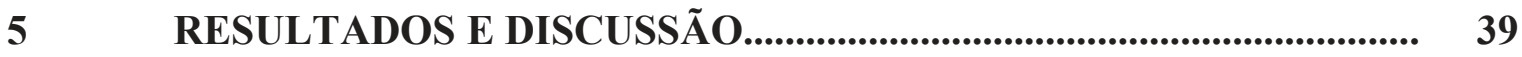

5.1 DESCRIÇÃO DOS TRABALHOS SELECIONADOS.............................. 44

5.2 POSSIBILIDADES E LIMITAÇÕES NO USO DE HORTAS ESCOLARES COMO FERRAMENTA DE ENSINO............................... 71

5.3 EXPERIÊNCIAS RELATADAS POR PROFESSORES QUE FORAM OU PODERÃO SER UTILIZADAS NO ENSINO DE BIOLOGIA ATRAVÉS 
DE HORTAS ESCOLARES................................................................. 73

CONCLUSÃO

REFERÊNCIAS BIBLIOGRÁFICAS................................................ 76

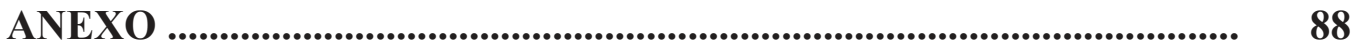




\section{INTRODUÇÃO}

A Política Nacional de Educação Ambiental (PNEA) preconiza que em caráter formal e não formal a educação ambiental deve estar presente em todos os níveis e modalidades do processo educativo, além de ser um componente essencial e permanente da educação nacional (BRASIL, 1999).

O uso de hortas escolares como ferramenta de ensino, apresenta-se como uma metodologia facilitadora do trabalho dos temas transversais, como: Meio Ambiente, Saúde, Trabalho e Consumo. A horta escolar, também representa um ambiente integrador da comunidade escolar, possibilitando a interação entre alunos, professores, funcionários e família, proporcionando desta forma um ambiente de integração social. Além disto, a horta pode ser utilizada como instrumento para o ensino das diferentes disciplinas, viabilizando o desenvolvimento de atividades práticas e prazerosas aos alunos, professores, funcionários e famílias (IRALA e FERNANDEZ, 2001).

O desenvolvimento de trabalhos com hortas escolares mostra-se como uma prática essencial na abordagem de temas relacionados a educação ambiental e educação para a saúde através dos aspectos nutricional e alimentar, uma vez que permitem uma compreensão da necessidade da preservação do meio ambiente, desenvolvem a capacidade do trabalho em equipe, proporcionam um maior contato com a natureza e modificação dos hábitos alimentares. Ademais, contribuem para o desenvolvimento de um estilo de vida sustentável, ou seja, menos impactante sobre o meio ambiente (CRIBB, 2010).

No entanto, é um grande desafio para o professor de ciências e biologia a efetivação de práticas de Educação Ambiental, pois, as dificuldades encontradas na realização destas práticas envolvem não somente a formação do professor de cada disciplina, mas também de fatores estruturais das escolas e escassez de recursos financeiros (AGUIAR et al, 2017).

Tendo em vista que o Ministério da Educação valoriza a elaboração de materiais didáticos que promovam a integração entre saúde, meio ambiente e desenvolvimento comunitário através de programas interdisciplinares, a proposta desta dissertação é realizar uma revisão integrativa da literatura e elaborar sugestões de práticas investigativas utilizando hortas escolares. A revisão integrativa visa responder as seguintes questões: quais as possibilidades e limitações no uso de hortas escolares como 
ferramenta de ensino? Quais experiências relatadas por professores que utilizam hortas escolares no ensino de biologia contribuiram no ensino da disciplina? A partir dessas respostas será possível analisar como se dará a construção e uso hortas como espaços pedagógicos, e como poderão ser exploradas em todas as suas potencialidades. 


\section{REFERENCIAL TEÓRICO}

\subsection{REVOLUÇÃO VERDE}

A expressão Revolução Verde foi concebida em 1966, em uma conferência em Washington, por William Gown. Essa revolução reivindicava o suprimento alimentar dos países por meio de tecnologias e não do sofrimento da população. Para compreender melhor os parâmetros da Revolução Verde, é necessário conhecer o contexto histórico no qual está inserida.

No contexto histórico que sucedeu a Segunda Guerra Mundial (1939-1945), muitos países europeus e asiáticos estavam desolados pela destruição da Guerra, havia muita fome e miséria, e como fazendas inteiras haviam sido destruídas, esses países não careciam de condições para suprir as necessidades alimentares da população. Durante esse período também havia uma grande tensão política entre os Estados Unidos e a antiga União Soviética que disputavam a hegemonia do mundo e buscavam países aliados, conforme ilustrado por Rosa:
O problema da fome tornava-se cada vez mais sério em várias partes do mundo, e o governo americano e os grandes capitalistas temiam que se tornasse elemento decisivo nas tensões sociais existentes em muitos países, o que poderia ampliar o número de nações sob o regime comunista, particularmente na Ásia e na América Central, tradicionais zonas de influência norte-americana (ROSA, 1998, p. 19).

Diante deste cenário, existia a grande necessidade de produzir mais alimentos utilizando pequenos espaços e em um curto período temporal, então, começaram a ser empregadas técnicas de cultivo agrícola que permitiam produzir mais em menos tempo. Neste período foram introduzidos na agricultura os primeiros produtos transgênicos; geneticamente modificados - utilização em larga escala de agroquímicos e outros insumos de origem industrial e início do processo de mecanização da agricultura. Esse período ficou conhecido como Revolução Verde (SILVA et al, 2005).

Devido ao contexto histórico pós Segunda Guerra Mundial, a denominada "Revolução Verde" irrompe no Brasil com a promessa de não somente a modernização do campo, mas também de erradicação da fome, aumento da produção, e, sobretudo com a implementação da nova era da agricultura e a busca de desenvolvimento aos 
países subdesenvolvidos (LAZZARI; SOUZA, 2017). Segundo Meirelles (1996), nesse período, ocorreu o aumento da importação de produtos químicos, da instalação de indústrias produtoras e formuladoras de agrotóxicos e do estímulo do governo através da criação do Programa Nacional de Defensivos Agrícolas (PNDA). O PNDA, dentre outras metas, condicionava a concessão de crédito rural ao agricultor, uma vez que, parte deste recurso fosse obrigatoriamente destinado a compra de agrotóxicos. Essa medida estimulava a produção e o consumo nacional de agrotóxicos. (FIDELES, 2006; SOARES, FREITAS e COUTINHO, 2005).

Percebe-se, neste cenário, que a Revolução Verde não foi apenas uma alternativa que visava a erradicação da fome e modernização do campo, mas detinha um viés político, social e econômico (ANDRADES; GANIMI, 2007). Segundo Graziano Neto (1985), a Revolução Verde deve ser vista como um "processo de transformação capitalista da agricultura, que ocorre vinculado as transformações gerais da economia brasileira recente" (p. 27).

Para Gonçalves (2004) a expressão "Revolução Verde" é um exemplo de técnica da política, pois diante do fenômeno de milhões de miseráveis se mobilizando para resolver seus problemas, o modelo capitalista de desenvolvimento aproveitou-se da oportunidade para "despolitizar a questão e torna-la uma questão técnica, de produção de sementes e alimentos" (p. 107-108). Alves (2013) aponta que o principal objetivo da Revolução Verde foi criar novas oportunidades de negócios, consolidar novos mercados e aumentar a estabilidade social nos países subdesenvolvidos.

No Brasil, a implantação da Revolução Verde ocorreu devido a uma junção de interesses: o interesse do governo brasileiro em modernizar e diversificar a produção agrícola; o interesse dos Estados Unidos em manter o Brasil como país aliado; e o interesse da sociedade em produzir mais e obter maiores lucros (ALVES, 2013).

Contudo, a Revolução Verde, além de gerar inúmeros impactos sociais provocou impactos ambientais imensuráveis como a contaminação dos alimentos, poluição das fontes hídricas, desertificação do solo, desmatamento, extinção da produção com rotação de culturas e seleção natural de pragas que se tornaram resistentes aos “agrotóxicos” (LAZZARI; SOUZA, 2017).

\subsection{AGROTÓXICOS, SER HUMANO E MEIO AMBIENTE}


A história do uso de agrotóxicos no mundo teve início a partir da Revolução Verde (DUQUE, 2016), e a introdução de insumos químicos na produção agrícola culminou em uma série de impactos ambientais e impactos na saúde humana. De acordo com a Lei $\mathrm{N}^{\circ} 7.802$ agrotóxicos são "[...] produtos e agentes de processos físicos, químicos ou biológicos para uso no cultivo, armazenamento e beneficiamento de produtos agrícolas, para alterar a composição da flora ou da fauna, a fim de preservá-las da ação de seres vivos nocivos" (BRASIL, 1989). De forma geral incluem fungicidas, herbicidas, inseticidas, acaricidas, bactericidas, entre outros (OPAS, 1997). É comum a defesa do termo "defensivo agrícola" em vários segmentos acadêmicos e empresariais. O termo "agrotóxico" ao invés de "defensivo agrícola" passou a ser utilizado no Brasil para denominar os venenos agrícolas, após grande mobilização da sociedade civil organizada. Mais do que uma simples mudança da terminologia, esse termo coloca em evidência a toxicidade desses produtos para o meio ambiente e a saúde humana.

Independente do termo utilizado, diversos estudos têm relacionado o uso dos agrotóxicos a diferentes manifestações relacionadas à saúde da população e ao meio ambiente. Tais manifestações variam de acordo com o princípio ativo, dose absorvida, forma de exposição e características individuais da pessoa exposta (ZAGANAS et al., 2013; GUNATILAKE et al., 2019; ALI et al., 2019). As consequências descritas na literatura compreendem alergias; distúrbios gastrintestinais, respiratórios, endócrinos, neurológicos, assim como neoplasias (WHO, 2010; GAMACHE et al., 2019; NDONWI et al., 2019; KORI et al., 2019).

Por ser amplamente utilizado em inúmeras atividades como agropecuária, produção industrial, madeireiro, silvicultura, manejo florestal, preservação de estradas, saúde pública, controle de algas, desinsetização e desratização, a utilização de agrotóxicos não se restringe ao meio rural e afeta, também, o meio urbano, tomando proporções incalculáveis e impossíveis de se dimensionar (MINISTÉRIO DA SAÚDE, 2016).

O relatório de análise de resíduos de agrotóxicos em alimentos de origem vegetal investigados no período de 2017 a 2018 pela ANVISA (2019) revelou que das 4.616 amostras de alimentos analisadas, 250 amostras (5,4\%) estavam com níveis de resíduos de agrotóxicos acima do permitido e 941 amostras (20,4\%) apresentavam 
agrotóxicos não autorizados para cultura. Os alimentos analisados incluem: arroz, abacaxi, laranja, manga, goiaba, uva, alface, chuchu, pimentão, tomate, alho, batatadoce, beterraba e cenoura, todos comumente encontrados na mesa de milhares de brasileiros diariamente.

Além da contaminação ao homem através do contato por meio da lavoura, ingestão de água ou consumo alimentar, agrotóxicos também exercem diferentes efeitos sobre plantas e animais. Por exemplo, Glifosato, um dos agrotóxicos químicos mais comercializados no Brasil de acordo com o Ministério da Saúde (2016), é capaz de inibir a atividade de enzimas antioxidantes e induzir o acúmulo de espécies reativas de oxigênio (ROS) em plantas, as quais acarretam em disfunções fisiológicas e danos celulares, além de diminuir a fotossíntese aumentando a degradação e alterando a biossíntese de clorofila (GOMES et al., 2016). Em animais, este mesmo agrotóxico descrito, está relacionado ao aumento de casos de má formação do feto e infertilidade em porcos e a danos metabólicos, estresse oxidativo e superprodução de ROS em peixes (KRÜGER et al., 2014a, 2014b).

Apesar dos efeitos nocivos decorrentes do uso desses produtos, o Brasil é considerado um dos maiores consumidores de agrotóxicos do mundo, enquanto o cenário mundial aponta para a proibição do uso da maior parte desses produtos (PEDROZA, 2013). Dados disponíveis no Dossiê Abrasco (ASSOCIAÇÃO BRASILEIRA DE SAÚDE COLETIVA, 2015, p. 29) informam que vinte e dois dos cinquenta princípios ativos mais empregados no Brasil estão banidos em outros países. No ano de 2019, o país concedeu registro a 474 agrotóxicos, conferindo o maior quantitativo registrado pelo Ministério da Agricultura dos últimos cinco anos. Segundo relatório da Organização das Nações Unidas para a Alimentação e a Agricultura (FAO, 2018), o Brasil ocupa o terceiro lugar no ranking dos países que mais consomem agrotóxicos no mundo, ficando atrás apenas da China e Estados Unidos da América; só no ano de 2018 foram consumidas mais de 377 toneladas de agrotóxicos, fato decorrente da flexibilidade da legislação e regulamentação relacionada ao registro e comercialização desses produtos químicos (CALDAS, 2000). Desde 2013, legislações têm sido propostas e aprovadas para fexibilizar a lei e ampliar a permissão para a utilização de agrotóxicos perigosos. A Lei $\mathrm{n}^{\mathrm{o}} 12.873$, de 24 de outubro de 2013, e o Decreto $n^{\circ} 8.133$, de 28 de outubro de 2013, por exemplo, passaram a permitir que, nos 
casos em que for declarada emergência fitossanitária, possam ser utilizados agrotóxicos sem registro no Brasil. Segundo Felipe Betim (2018), atualmente, para implementar uma nova substância no Brasil ela precisa ser avaliada pelo Ministério da Agricultura, pelo Instituto Brasileiro do Meio Ambiente e Recursos Naturais (IBAMA) vinculado ao Ministério do Meio Ambiente, e pela ANVISA, aliado ao Ministério da Saúde. O sistema adotado tem uma duração média de 4 a 8 anos, tempo considerado insuficiente para a análise de risco ou dose segura e que não permite definir instrumentos, técnicas e parâmetros capazes de garantir o uso correto e que não cause danos graves no futuro.

\subsubsection{AGROTÓXICOS E SEUS EFEITOS SOBRE O SER HUMANO}

São inúmeros os estudos que associam o uso de agrotóxicos e seus efeitos nocivos à saúde humana (ALAVANJA, 1999; COLOSSO; TIRAMANI; MARONI, 2003; PERES; MOREIRA, 2003; SANTOS, 2003). Os agrotóxicos podem interferir na saúde humana causando dois tipos de efeitos:

1) efeitos agudos, ou aqueles resultantes da exposição a concentrações de um ou mais agentes tóxicos capazes de causarem dano efetivo aparente em um período de 24 horas;

2) efeitos crônicos, ou aqueles resultantes de uma exposição continuada a doses relativamente baixas de um ou mais produtos (PERES, MOREIRA e DUBOIS, p.32-33).

Os efeitos agudos dos agrotóxicos, podem ser classificados como medianamente ou pouco tóxicos, já os efeitos crônicos, podem ocorrer meses, anos ou até décadas após a exposição, podendo manifestar-se em várias doenças como cânceres, má formação congênita, distúrbios endócrinos, neurológicos e mentais (CARNEIRO et al., 2012). Recentemente, estudos vêm apontando a relação entre o aumento do uso de agrotóxicos e a incidência de câncer no Brasil (CHRISMAN et al., 2009), ou ainda casos de depressão e suicídios (FARIA; FASSA; FACCHINI, 2007).

No Brasil, a segunda principal causa de intoxicação é por agrotóxicos, depois de medicamentos, entretanto, a morte dos intoxicados ocorre com maior incidência entre os que tiveram contato com agrotóxicos (ANVISA, 2009). O impacto causado pelo uso excessivo de agrotóxicos nos alimentos tem alarmado a população, uma vez que pouco se sabe sobre quantidade de agrotóxicos que está sendo ingerido através da alimentação, 
pois os rótulos dos alimentos não especificam qual tipo de insumo foi utilizado na sua produção. Existem três vias responsáveis pelo impacto direto da contaminação humana: a ocupacional, caracterizada pela contaminação dos trabalhadores que manuseiam essas substâncias; a ambiental, que ocorre por meio de dispersão/distribuição dos agrotóxicos ao longo dos diversos componentes do meio ambiente; e a alimentar, que se dá pela ingestão de produtos contaminados por agrotóxicos (MOREIRA, JACOB, PERES, 2002).

A contaminação dos trabalhadores agrícolas por essas substâncias pode ocorrer através da ingestão, da inalação ou da absorção dérmica. Dentre as atividades que constituem atividades de risco para intoxicação por agrotóxicos estão: irrigação, aragem, colheita, armazenagem de produtos, embalagem, fertilização do solo e até o cuidado de animais com o uso de substâncias veterinárias (SANTANA; MOURA; NOGUEIRA, 2013). A não utilização de Equipamentos de proteção Individual (EPI) em qualquer uma das etapas do manejo de defensivos agrícolas contribui para o aumento da probabilidade de intoxicação (TAVARES et al., 2020).

A exposição ocupacional aos pesticidas tem um forte impacto na saúde pública (DAMS, 2006), mas a contaminação de seres humanos também ocorre através da alimentação (CISCATO, 2008), uma vez que, muitos alimentos comercializados nas cidades podem apresentar resíduos de pesticidas (DAMS, 2006). Esta contaminação dos alimentos pode ocorrer em uma das fases de produção, no transporte ou armazenamento dos produtos, como consequência de uma possível manipulação errada dos trabalhadores ao uso excessivo dos pesticidas (JOSÉA et al., 2004) ou da comercialização de produtos sem respeitar o período de carência da aplicação de pesticidas. Tais medidas colaboram para a contaminação direta tanto dos produtores quanto dos consumidores, ocorre também a contaminação através da ingestão pelo ser humano de animais contaminados por biomagnificação (acúmulo do pesticida ao longo da cadeia alimentícia) ou o contato com o meio ambiente contaminado podem gerar intoxicações (DIREITO, FIGUEIRÓ, FLORES, 2012).

\subsubsection{AGROTÓXICOS E SAÚDE HUMANA}


Segundo a Organização Mundial da Saúde (OMS) são registradas 20 mil mortes por ano devido ao consumo de agrotóxicos. No Brasil, os dois principais sistemas de notificação de intoxicação são o Sistema de Informação de Agravos de Notificação (SINAN) e o Sistema Nacional de Informações Tóxico-Farmacológicas (SINITOX), gerenciados pelo Ministério da Saúde e pela Fundação Oswaldo Cruz (FIOCRUZ), respectivamente. Segundo dados disponíveis no Sinan, nos últimos 11 anos (2007-2017) foram notifcados 107.535 casos de intoxicação por agrotóxicos no Brasil, 3.452 deles evoluindo para morte (letalidade de 3,21\%). Do total de ocorrências, 39.698 intoxicações foram por agrotóxico de uso agrícola, que resultaram em 1.829 mortes (letalidade de 4,59\%). Estima-se que nos últimos anos, ocorreu um crescente aumento de intoxicações e óbitos, porém muitos casos não são notificados pelos sistemas de informação nacionais (BURALLI et al., 2020).

Vários estudos demonstram uma associação significativa entre agrotóxicos e o processo carcinogênico e outros efeitos à saúde de longo prazo, neoplasias como o câncer de próstata, pulmão, mama e estômago estão ligadas a exposição a agrotóxicos (PLUTH; ZANINI; BATTISTI, 2019; KRAWCZYK et al., 2019).

Doenças genéticas, como por exemplo, doenças neurodegenerativas, hemofilia, doença de Alzheimer, diversos tipos de câncer, esclerose múltipla, hipertensão arterial, Síndrome de Down, Síndrome de Turner e doenças cardíacas, estão concentradas, principalmente, na população rural que tem ou tiveram contato com agrotóxicos, desde o manuseio e aplicação direta do produto, como aqueles de contato indireto (LEDDA et al., 2021).

Pesquisadores da Universidade Federal do Mato Grosso (UFMT) realizaram uma pesquisa no município de Lucas do Rio Verde, no estado do Mato Grosso com o objetivo de determinar resíduos de agrotóxicos no leite de mães residentes no município que foi amplamente ocupado pelo agronegócio, todas as amostras coletadas apresentaram resíduos de pelo menos um dos agrotóxicos analisados, em uma das mães que participou da pesquisa foram detectados seis tipos diferentes de agrotóxico no leite materno, o leite contaminado quando consumido pelos recém-nascidos provoca agravos à saúde, pois estes são mais vulneráveis à exposição a agentes químicos (PALMA, 2011). 
A Organização Mundial da Saúde, através da Agência Internacional de Pesquisa em Câncer (IARC), avaliou o potencial cancerígeno de cinco agrotóxicos organofosforados, a IARC identificou o herbicida glifosato e os inseticidas malationa e diazinona, como prováveis causadores de câncer, os inseticidas tetraclorvinfós e parationa foram classificados como possíveis agentes carcinogênicos (IARC, 2015). Fato intrigante é que todos os agrotóxicos citados anteriormente são amplamente utilizados na agricultura brasileira (soja e milho) e também no controle de vetores em campanhas de saúde pública (INCA, 2015). De acordo com o posicionamento do Instituto Nacional do Cãncer (INCA), o uso intensivo de agrotóxicos, além de contribuir para a degradação ambiental, está associado a intoxicações de trabalhadores rurais e da população em geral, pois devido a sua fácil dispersão contaminam todas as fontes de recursos vitais, incluindo alimentos, solos, águas, leite materno e ar.

\subsubsection{AGROTÓXICOS E IMPACTOS AMBIENTAIS}

O uso indiscriminado de pesticidas e sem conhecimento dos efeitos secundários destes pelos agricultores, acarretou danos ao meio ambiente e, logo, a qualidade de vida do homem ficou comprometida (VIEIRA et al., 1999). Os agrotóxicos podem ser classificados quanto a periculosidade ambiental, em classes que variam de I a IV: produtos altamente perigosos ao meio ambiente (Classe I), produtos muito perigosos ao meio ambiente (Classe II), produtos perigosos ao meio ambiente (Classe III) e produtos pouco perigosos ao meio ambiente (Classe IV) (RIBEIRO et al., 2007).

As propriedades físico-químicas dos agrotóxicos, a quantidade e a frequência de uso, formas de aplicação, assim como as características bióticas e abióticas do ambiente e as condições meteorológicas determinarão o destino dos agrotóxicos no ambiente. Essas condições são variáveis, portanto é impossível prever um modelo de comportamento dos agrotóxicos no ambiente (RIBAS e MATSUMURA, 2009). Os agrotóxicos são produtos de fácil dispersão e permanecem por um longo tempo no ambiente (MOREIRA et al., 2002).

Os recursos hídricos agem como integradores de todos os processos biogeoquímicos em qualquer região, assim, superficiais ou subterrâneos, são os principais destinos de pesticidas (RIBAS e MATSUMURA, 2009). Segundo o Sistema 
de Vigilância da Qualidade da Água para Consumo Humano (SISAGUA), mais de 1.300 cidades encontraram resíduos de agrotóxicos na água que sai das torneiras e, 0,3\% de todos os casos de pesticidas detectados na água, nas medições feitas entre 2014 a 2017, ultrapassaram o nível considerado seguro para cada substância.

Através do escoamento da água da chuva e da irrigação, os agrotóxicos podem ser transportados dos locais que foram aplicados para outros compartimentos ou podem contaminar as fontes subterrâneas - pela drenagem e percolação (passagem lenta de um líquido através de um meio filtrante) no solo. No solo os resíduos de agrotóxicos podem ser liberados para a atmosfera, águas subterrâneas e organismos vivos, uma vez que estes podem utilizar esses compostos como fonte de carbono (MENDONÇA, 2018).

Resíduos de agrotóxicos também podem ser encontrados em estações de tratamento de água urbanas, principalmente devido ao seu uso não agrícola, como a aplicação de manutenção de gramados, no controle de vegetação industrial, em saúde pública e em culturas não-agrícolas, como a silvicultura comercial e horticultura e plantas em viveiros (KOCK-SCHULMEYER et al., 2013).

Segundo Spadotto et al. (2004), os agrotóxicos podem alterar não só a diversidade e a composição de espécies, como também a biomassa, alterando a fertilidade do solo. Dessa forma, o excesso de aplicação de agrotóxicos tem provocado inúmeras consequências negativas sobre o ambiente, como o desaparecimento de algumas espécies de insetos usadas no controle biológico de pragas, resultando na aparição de novas pragas (RIBEIRO et al., 2007). Calcula-se que aproximadamente 500 espécies de pragas, $60 \%$ das quais são perigosas para a agricultura, têm desenvolvido resistências genéticas devido a exposição repetida a pesticidas (BARROW, 1995; MOTT e SNYDER, 1987). Organismos não alvos como algas, abelhas, peixes, aves e ratos são afetados pelo uso de agrotóxicos, refletindo sobre a dieta alimentar e reprodução desses indivíduos (REBELO e CALDAS, 2014). Os resíduos de agrotóxicos que contaminam as fontes hídricas, provocam a contaminação de peixes, crustáceos, moluscos e outros animais aquáticos (MENDONÇA,2018). Em um estudo realizado por Ferreira (2016), observou-se que produtos como o glifosato e diuron ocasionaram danos nas brânquias de quatro espécies de peixes amazônicos. O efeito negativo dos agrotóxicos também pode interferir na capacidade reprodutiva das aves e redução das espécies de aves e peixes (CASTRO e CONFALONIERI, 2005; JARDIM et al, 2009). 


\subsection{AGROECOLOGIA}

Percebendo os impactos ambientais e sociais provocados pelo modelo agrícola adotado após a Revolução Verde, a sociedade começou a demonstrar uma crescente preocupação com a preservação ambiental, o que culminou na evolução do movimento ambientalista, questionando o modelo produtivista e economicista vigente e indicando a necessidade urgente de transformações sociais profundas, que ressignifiquem a relação sociedade-natureza. Essas mudanças buscam uma relação mais harmônica entre a produção de alimentos e a conservação ambiental. Neste sentido, surgem formas alternativas de agricultura, como a agricultura orgânica, a agricultura natural, a agricultura biodinâmica, entre outras (CANDIOTTO e MEIRA, 2014). Neste ambiente de busca por alternativas de cultivo sustentáveis que possibilitem a interação entre os seres humanos e os recursos ambientais, de forma que a ação do homem seja componente dos processos ecológicos que acontecem nos agroecossistemas, nasceu a Agroecologia (CAPORAL e COSTABEBER, 2004; MAPA, 2012). Surgida nos anos 1970, a agroecologia pode ser considerada como a ciência ou campo de conhecimentos de natureza multidisciplinar, cujos ensinamentos pretendem contribuir na construção de estilos de agricultura de base ecológica e na elaboração de estratégias de desenvolvimento rural, tendo-se como referência os ideais da sustentabilidade numa perspectiva multidimensional (AZEVEDO; PELICIONI, 2012).

O que se quer, então, é uma nova a abordagem da agricultura e do desenvolvimento agrícola, que construa sobre aspectos de conservação de recursos da agricultura tradicional local, enquanto, ao mesmo tempo, se exploram conhecimentos e métodos ecológicos modernos. Esta abordagem é configurada na ciência da agroecologia, que é definida como a aplicação de conceitos e princípios ecológicos no desenho e manejo de agroecossistemas sustentáveis (GLIESSMAN, 2001, p. 53-54).

Segundo Altieri (1987) a agroecologia utiliza os agroecossistemas como unidades de estudo, através de um enfoque multidimensional, utilizando uma abordagem que engloba os princípios agronômicos, ecológicos e socioeconômicos para compreender o efeito das tecnologias sobre o sistema agrícola e a sociedade como um todo. A agroecologia estuda as relações entre homem e natureza, buscando sempre a 
sustentabilidade ecológica, social, econômica, cultural, política e ética, através de uma relação harmônica com a natureza, integrando saberes acadêmicos e conhecimento comum nas práticas agrícolas (DOS SANTOS e OLIVEIRA, 2015).

Através dos métodos desenvolvidos pela Agroecologia, surge a possibilidade de implementar um manejo produtivo e sustentável dos recursos naturais, atrelada a melhoria das condições locais das comunidades rurais, oferecendo uma segurança baseada na autossuficiência alimentar, que será possível na medida em que houver alternativas produtivas que permitam melhorar suas condições de vida e aproveitar seus recursos de forma sustentável (LEFF, 2002).

No entanto, para que o modelo convencional de cultivo agrícola possa ser substituído pelo modelo agroecológico, existe a dependência da intervenção humana. A transição agroecológica só se torna possível na medida em que houver uma mudança nas atitudes e valores dos atores sociais em relação ao manejo e conservação dos recursos naturais (CAPORAL, COSTABEBER, 2004). A agroecologia possibilita a fundamentação de propostas de ensino que permitem a formação de cidadãos mais conscientes da relação entre as crises ecológica, econômica e social vigentes e reforça a promoção da educação ambiental (GARCIA, 1999), além de contribuir para a aproximação entre o agricultor e o técnico ou pesquisador (SEVILLA GUSMÁN, 2002), sinalizando para a promoção de um intercâmbio entre escola e a comunidade na qual se insere e no acolhimento do conhecimento popular.

Nesse contexto, o ambiente escolar destaca-se por ser um importante espaço que contribui para a formação de indivíduos/cidadãos responsáveis e críticos, preparados para discutir sobre questões relacionadas ao meio ambiente e sociedade (BARROS, DAMBROS e MACHADO, 2012).

\subsection{EDUCAÇÃO AMBIENTAL NAS ESCOLAS}

A implantação de programas educacionais com ênfase na educação ambiental mostra-se como ferramenta importante na sensibilização de questões relacionadas a problemática ambiental (SANTOS, 2007). A escola tem o papel de sensibilizar o aluno, estimulando-o a buscar valores que o conduza a convivência harmoniosa com a natureza, além de auxiliar o mesmo a analisar criticamente os princípios que levaram à 
destruição inconsciente dos recursos naturais e espécies extintas, fazendo-o ter consciência de que as reservas da natureza devem ser usadas de forma racional, buscando evitar o desperdício e considerando a reciclagem como processo vital (EFFTING, 2007).

Segundo Effting (2007) a Política Nacional de Educação Ambiental legaliza seus princípios, transforma em objeto de políticas públicas e fornece à sociedade um instrumento de cobrança para a promoção da educação ambiental (EA).

Moreira (2011, p.21), considera que a inserção da educação ambiental no currículo escolar de forma inter e transdisciplinar é importante para a construção do conhecimento e reorientação de atitudes para a construção de sociedades sustentáveis.

Nesta perspectiva, a Educação Ambiental assume o grande desafio de promover uma mudança de valores éticos como cooperação, generosidade, solidariedade, tolerância, dignidade e respeito à diversidade do meio ambiente (CARVALHO,2006). Para se alcançar este objetivo, torna-se necessário que os professores desenvolvam em suas aulas a educação ambiental com uma abordagem crítica, em uma perspectiva interdisciplinar, transversal e contextualizada (RAMOS e VASCONCELOS, 2015). Neste contexto, a escola deve aproveitar a experiência social que os educandos possuem e discutir os problemas ambientais já existentes, como por exemplo, a poluição do solo e da água e suas implicâncias na saúde humana (OLIVEIRA, 2000), através desta problematização é possível uma aproximação do aluno com o tema meio ambiente, despertando o interesse do mesmo e instigando-o a desenvolver um pensamento crítico e criativo (CUBA, 2010). Conforme define Reigota (2002, p.58), o papel da educação ambiental enquanto um tema transversal parte de "uma proposta filosófica e pedagógica que considera a escola um centro de questionamentos e produção de alternativas sociais, políticas e culturais mais sintonizadas com o seu tempo". Assim, o processo educativo, ao mesmo tempo em que constrói o ser humano como humano, constrói também, a humanidade (TOZONI-REIS e CAMPOS, 2014).

Uma vez que a Educação Ambiental se tornou exigência no currículo, tanto no âmbito, municipal, estadual, quanto federal, é preciso considera-la como uma importante aliada do currículo escolar na busca de um conhecimento integrado (NARCIZO, 2009). 
Nas palavras de Trajber (2011, p. 24) "a Educação Ambiental se torna, assim, uma política pública voltada para o futuro que, tendo as escolas como referência de espaços educadores para suas comunidades, educa para sociedades sustentáveis".

As Diretrizes Curriculares Nacionais para a Educação Ambiental (DCNEA), preconizam que as escolas devem adotar uma abordagem ambiental que considere a interface entre a natureza, o sociocultural, a produção, o trabalho, o consumo, superando a visão despolitizada, acrítica, ingênua e naturalista ainda muito presente na prática pedagógica das instituições de ensino (BRASIL,2001).

No entanto, cabe ressaltar, que mesmo que a Educação ambiental, seja um conteúdo obrigatório no currículo, ainda existem muitas barreiras na implementação da Educação Ambiental no âmbito escolar. Segundo Oliveira (2000, p.100) para que ocorra a efetiva implementação da Educação Ambiental no âmbito escolar, três dificuldades devem ser vencidas, sendo elas a busca de alternativas metodológicas, a rigidez da estrutura curricular e a sensibilização do corpo docente.

Para uma implementação efetiva da EA, as escolas devem posicionar-se de forma colaborativa e estimular a autonomia de todos os envolvidos, sejam eles discentes, docentes ou comunidade escolar (ANDRADE, 2020). Cribb (2010) ressalta que para um trabalho de ensino-aprendizagem alcançar seus objetivos, precisa ser conduzido a partir de uma visão integradora, adequada as realidades ecológica, econômica e sociocultural de cada indivíduo, de cada sociedade e de cada região. Neste sentido, para que sejam abordadas questões ambientais, deverão ser envolvidos diversos campos do saber e utilizados métodos interdisciplinares que levem em consideração todos os aspectos que compõem a questão ambiental e sociocultural, estabelecendo um diálogo entre as diversas culturas presentes nos mais diversos espaços/tempos sociais, e desta forma produzir conhecimentos válidos e necessários (CAPRA, 1982; LEFF, 2002; ALVES, 2004; OLIVEIRA ,2004).

Posto isto, consideramos que as hortas escolares apresentam-se como um espaço propício para abordagem de temas relacionados a educação ambiental.

\subsection{HORTAS NA ESCOLA}


A horta é uma prática bastante rica em conhecimento, que pode ser utilizada como ferramenta de ensino em várias disciplinas, tais como ciências, biologia, matemática, física, entre outras, permitindo que professores e alunos possam entender melhor o nosso mundo e suas potencialidades. Além de promover o resgate do cultivo da terra, a reflexão sobre a importância do consumo de alimentos orgânicos, preservação do meio ambiente, interação entre comunidades escolares e a interdisciplinaridade (MAGALHÃES; GAZOLA, 2002; SANTOS et al, 2012).

Segundo Fernandes (2007), através das hortas escolares é possível melhorar a educação dos estudantes através de uma aprendizagem ativa e a integração de múltiplos conteúdos, além de proporcionar aos discentes, experiências de práticas ecológicas e desta forma cultivar hábitos de alimentação saudável entre os educandos e desenvolver técnicas de cultivo orgânico.

Cribb (2010, p.49) afirma que atividades desenvolvidas em hortas escolares, oferecem a oportunidade de desenvolver aulas de campo e permitem contato direto com a natureza, desta forma, os alunos, além de observarem na prática os ciclos alimentares aprendem a respeitar a natureza.

Muitos autores destacam que as atividades com hortas escolares além de proporcionarem um contato direto com a natureza, contribuem no desenvolvimento de uma série de novas aprendizagens, tanto no educando quanto na comunidade escolar (IRALA, FERNANDEZ e RECINE, 2001). Bandeira (2013, p.57) lista vários objetivos que podem ser alcançados com hortas escolares, mencionados no quadro 1 .

\section{Quadro 1 - Objetivos que podem ser alcançados com hortas escolares segundo}

\section{Bandeira.}

$>$ Conhecer e apropriar-se do conceito de cidadania.

$>$ Analisar e discutir as ações do ser humano em relação a sua cidadania.

$>$ Perceber-se como sujeito transformador na/da sociedade.

$>$ Discutir o papel do cidadão na construção de sua formação.

$>$ Refletir se seus direitos estão sendo respeitados e instigá-los a procurar caminhos sem o uso de violência e não desrespeitar os outros.

$>$ Empregar corretamente a quantificação como a contagem, a classificação e o espaço como algo importante em nossa vida.

$>$ Compreender a importância do respeito à memória do coletivo e individual.

$>$ Entender nossa responsabilidade na Preservação Ambiental.

$>$ Conhecer diferentes tipos de solo, seus cuidados e sua importância para a pessoa do campo e consequentemente para a cidade.

$>$ Construir hábitos responsáveis no uso da água e entender nossa responsabilidade sobre a preservação.

$>$ Compreender o processo da fotossíntese e outros processos naturais das plantas.

$>$ Identificar pragas e doenças das plantas e aprender a combatê -las sem o uso do 


\section{agrotóxico.}

$>$ Identificar diferentes formas de plantio.

$>$ Conhecer as diferentes formas de propagação das plantas.

$>$ Conhecer e saber como utilizar ferramentas e utensílios da horta.

$>$ Conhecer e utilizar diferentes formas de canteiros.

$>$ Aprender a construir canteiros com materiais reaproveitáveis.

$>$ Aprender a construir composteiras para a produção de adubos orgânicos.

$>$ Aprender a identificar e saber utilizar diferentes tipos de adubo.

$>$ Refletir sobre a alimentação saudável e seu benefício para a saúde.

Fonte: adaptado de Bandeira (2013, p.57).

Ao ser planejada, buscando alcançar os objetivos propostos por Bandeira, a horta escolar conduz a uma reflexão e mudanças de valores e atitudes, no que diz respeito aos recursos naturais, tornando a escola um espaço de formação e informação. Também proporciona a aprendizagem de conteúdo, permitindo que o educando seja capaz de interferir na realidade local (FREIRE, 2008).

No entanto, para que o ensino ocorra de forma contextualizada, é necessário que os alunos sejam cativados a participarem das práticas pedagógicas desenvolvidas em sala de aula ou até mesmo fora dela. Perrenoud (2000) acrescenta que para a aprendizagem ocorrer de forma significativa, o professor deve conduzir os alunos no desenvolvimento de atividades de pesquisa e de projetos que envolvam conhecimento prévio, assim, muitos professores têm utilizado a metodologia investigativa no desenvolvimento de suas aulas. O Ensino de Ciências por investigação é uma alternativa que estimula o educando a desenvolver suas habilidades de observação e argumentação, análise e interpretação de dados, trabalho colaborativo e autonomia no aprendizado. (MUNFORD e LIMA, 2007; SOLINO e GEHLEN, 2014;). Nestas circunstâncias, consideramos que o uso de práticas investigativas associadas as práticas com hortas escolares, constituem uma ferramenta importante para o Ensino de Biologia.

\subsubsection{HORTAS NO ENSINO DE BIOLOGIA}

Segundo a Base Nacional Currricular Comum (BNCC), a área de Ciências da Natureza deve colaborar para a construção de uma base de conhecimentos contextualizada, que prepare os estudantes para se tornarem cidadão críticos, capazes de tomar iniciativas, elaborar argumentos e apresentar soluções alternativas às situações 
problemas observadas no dia-a-dia; para garantir a formação de jovens preparados para os desafios da comtemporaneidade a BNCC do Ensino Médio da área de Ciências da natureza e suas tecnologias deve garantir aos estudantes o desenvolvimento de três competências específicas:

1. Analisar fenômenos naturais e processos tecnológicos, com base nas relações entre matéria e energia, para propor ações individuais e coletivas que aperfeiçoem processos produtivos, minimizem impactos socioambientais e melhorem as condições de vida em âmbito local, regional e/ou global.

2. Construir e utilizar interpretações sobre a dinâmica da Vida, da Terra e do Cosmos para elaborar argumentos, realizar previsões sobre o funcionamento e a evolução dos seres vivos e do Universo, e fundamentar decisões éticas e responsáveis.

3. Analisar situações-problema e avaliar aplicações do conhecimento científico e tecnológico e suas implicações no mundo, utilizando procedimentos e linguagens próprios das Ciências da Natureza, para propor soluções que considerem demandas locais, regionais e/ou globais, e comunicar suas descobertas e conclusões a públicos variados, em diversos contextos e por meio de diferentes mídias e tecnologias digitais de informação e comunicação (TDIC) (COMPETÊNCIAS ESPECÍFICAS DE CIÊNCIAS DA NATUREZA, BNCC, 2018, p.539).

Deste modo, o desenvolvimento de hortas no ambiente escolar constitui um espaço favorável à aprendizagem, que permite desenvolver as competências específicas da BNCC, pois possibilitam o desenvolvimento do processo de ensino-aprendizagem através de aulas práticas, desperta valores sociais como participação, relação interpessoal, senso de responsabilidade e sensibilização quanto às questões relacionadas ao meio ambiente e auxiliam no processo de formação de cidadão críticos, capazes de analisar e discutir as melhores formas para manter um ambiente saudável (PEREIRA et al, 2012; MARTINEZ e HLENKA, 2017).

O desenvolvimento de sequências didáticas utilizando hortas escolares como ferramentas de ensino, permite que os professores de Biologia desenvolvam as competências e habilidades propostas pela BNCC, uma vez que, através das hortas escolares poderão ser discutidos temas como a importância do processo fotossintético e sua relação com a luz, oxigênio, gás carbônico e água para o desenvolvimento das plantas; relacionar o cultivo da horta aos ciclos biogeoquímicos como os ciclos do carbono, nitrogênio e oxigênio; compreender a propagação das plantas (sexuada e 
assexuada ou vegetativa); realizar a classificação taxonômica dos seres vivos, como o nome científico das hortaliças e animais encontrados na horta; podem ser trabalhados temas relacionados ao controle biológico, relações ecológicas, cadeias e teias alimentares através da observação dos inimigos naturais, pragas e doenças que interferem nas plantas, formas de combater as pragas e doenças, demonstrando desta forma a possibilidade de desenvolver o cultivo orgânico de hortaliças (REZENDE, et al. 2014).

\subsection{ENSINO DE BIOLOGIA POR INVESTIGAÇÃO}

A preocupação de muitos pesquisadores na área de educação em Ciências é a maneira como o conhecimento científico é trabalhado nas escolas, e o ensino de Ciências por investigação têm sido interesse de estudo de muitos pesquisadores (CARVALHO, et al., 1998; LIMA; MUÉS, 2006; CASTRO, 2016). Grandy e Duschl (2007) destacam que a agenda do ensino por investigação ganha lugar nos currículos pelos objetivos de levar os estudantes a realizarem investigação e de desenvolver entre os estudantes um entendimento sobre o que seja a investigação científica.

O Ensino de Ciências por Investigação (EnCI) utiliza estratégias didáticas que buscam envolver ativamente os alunos no processo de aprendizagem, através da geração de questões-problema nos quais a investigação é condição para resolvê-las, por meio da coleta, análise e interpretação de dados que levem a formulação e comunicação de conclusões baseadas em evidências e reflexão sobre o processo (MELVILLE et al., 2008). Segundo Sasseron (2015) o Ensino de Ciências por investigação é uma perspectiva de ensino ou abordagem didática em que o professor exerce a função de mediador e auxilia estudantes a resolverem problemas a eles apresentados, através da interação com seus colegas e da sistematização de conhecimentos pré-existentes.

O termo investigação em Ciências surgiu na década de 70 e assumiu vários significados e tendências, conforme o contexto aplicado (PARENTE, 2012). Para que uma atividade possa ser denominada como investigativa, deve "estar acompanhada de situações problematizadoras, questionadoras e dialógicas, envolvendo a resolução de problemas e levando à introdução de conceitos” (CARVALHO et al., 2014, p.47). 
Segundo Munford e Lima (2007) é bastante comum as pessoas acreditarem que o Ensino de Ciências por investigação está diretamente associado ao desenvolvimento de atividades práticas e experimentações, no entanto, nem sempre atividades experimentais são desenvolvidas de forma investigativa e atividades que são consideradas "não práticas" podem ser trabalhadas de forma totalmente investigativa. Em seus estudos, os autores também observaram que muitos professores presumem que o EnCI deve envolver atividades onde o aluno atua de forma autônoma durante todo o processo ou que todos os conteúdos devem ser abordados de forma investigativa, mas para os autores, o EnCI consiste em uma estratégia de ensino inovadora que o professor poderá utilizar para diversificar suas aulas.

Diante de tantas concepções sobre o que é o Ensino de Ciências por investigação, pergunta-se, como trazer uma abordagem investigativa para sala de aula?

Segundo Scarpa, Sasseron e Silva (2017) a investigação pode ocorrer em aulas de laboratório, de leitura, de escrita e até mesmo em aulas expositivas, o mais importante não é o material em uso, mas as estratégias adotadas pelo professor. Para os autores, a diferença entre o ensino tradicional de uma abordagem investigativa está na forma como as ações são desenvolvidas e na aproximação que as mesmas têm com a própria ciência. O processo investigativo dá-se a partir da proposição de uma situação problema, em seguida iniciam-se as buscas por soluções através da elaboração e avaliação de hipóteses, seguida da construção de explicações para o problema. O professor gerencia o debate, apontando aos alunos novas questões e caminhos para a investigação. O processo de elaborar perguntas, mover uma ação e refletir sobre os resultados é chamado pelos autores de Ciclo de Indagación (Figura 1) ou, em português, ciclo de indagação ou ciclo de investigação (ARANGO, CHAVES; FEISINGER, 2009). 


\section{Figura 1 - Ciclo de investigação.}

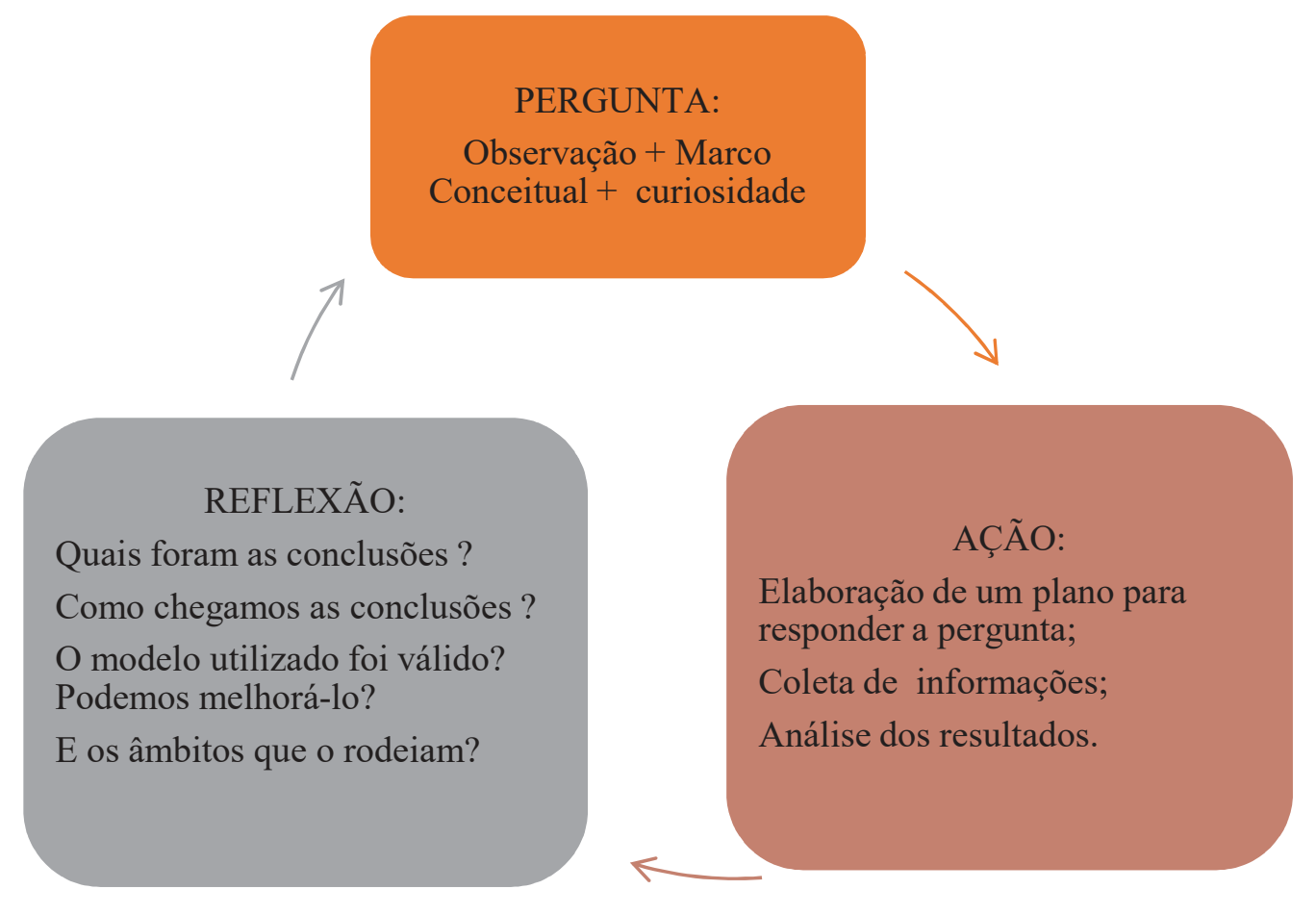

Fonte: Ciclo de Indagação, adaptado de ARANGO, CHAVES, FEINSINGER, 2009, p.2.

Brito e Fireman (2018) entendem que o ensino de Ciências por investigação, permite aos alunos aprender Ciências sobre três dimensões: "Aprender Ciências, aprender a fazer Ciências e aprender sobre Ciências". Nessa perspectiva "o ensino proporciona ao aluno aprender Ciências enquanto cultura para ler, pensar, falar, perceber e sentir o mundo" (BRITO E FIREMAN ; 2018). 


\section{OBJETIVO GERAL}

Realizar uma revisão integrativa da literatura sobre as possibilidades e limitações do uso de hortas no ensino de biologia e elaborar sugestões de metodologias ligadas a práticas com hortas escolares para estudantes do ensino médio.

\subsection{OBJETIVOS ESPECÍFICOS}

- Analisar experiências de professores que utilizaram hortas escolares como ferramenta de ensino;

- Descrever os artigos selecionados;

- Elaborar um manual com sugestões de práticas investigativas com hortas escolares que contribuam para o Ensino de Biologia no Ensino Médio. 


\section{METODOLOGIA}

A abordagem deste estudo é qualitativa com objetivo exploratório e descritivo com procedimentos técnicos de pesquisa bibliográfica. Foi realizado um estudo de revisão integrativa da literatura em base de dados eletrônica. No presente estudo, foram incluídos artigos originais, dissertações, monografias e trabalhos de conclusão de curso (TCC), todos no idioma português, publicados entre os anos de 2010 e 2019; foram incluídos neste estudo apenas artigos que apresentassem ações/práticas com hortas escolares aplicáveis ao ensino de Biologia no Ensino Médio. Artigos duplicados, artigos que contemplavam estudos não aplicáveis ao ensino de Biologia e relatos de experiências e projetos não concluidos foram excluídos.

A busca eletrônica foi conduzida na base de dados Periódicos Capes e Google acadêmico. O descritor utilizado foi "horta na escola". Foi realizada uma análise inicial dos títulos e resumos dos artigos, dissertações, monografias e selecionados os estudos que preenchiam os critérios de inclusão, ou que, não permitiam se ter certeza de que deveriam ser excluídos. A figura 2 mostra um fluxograma contendo as etapas de seleção dos artigos.

\section{Figura 2 - Fluxograma da seleção dos artigos}

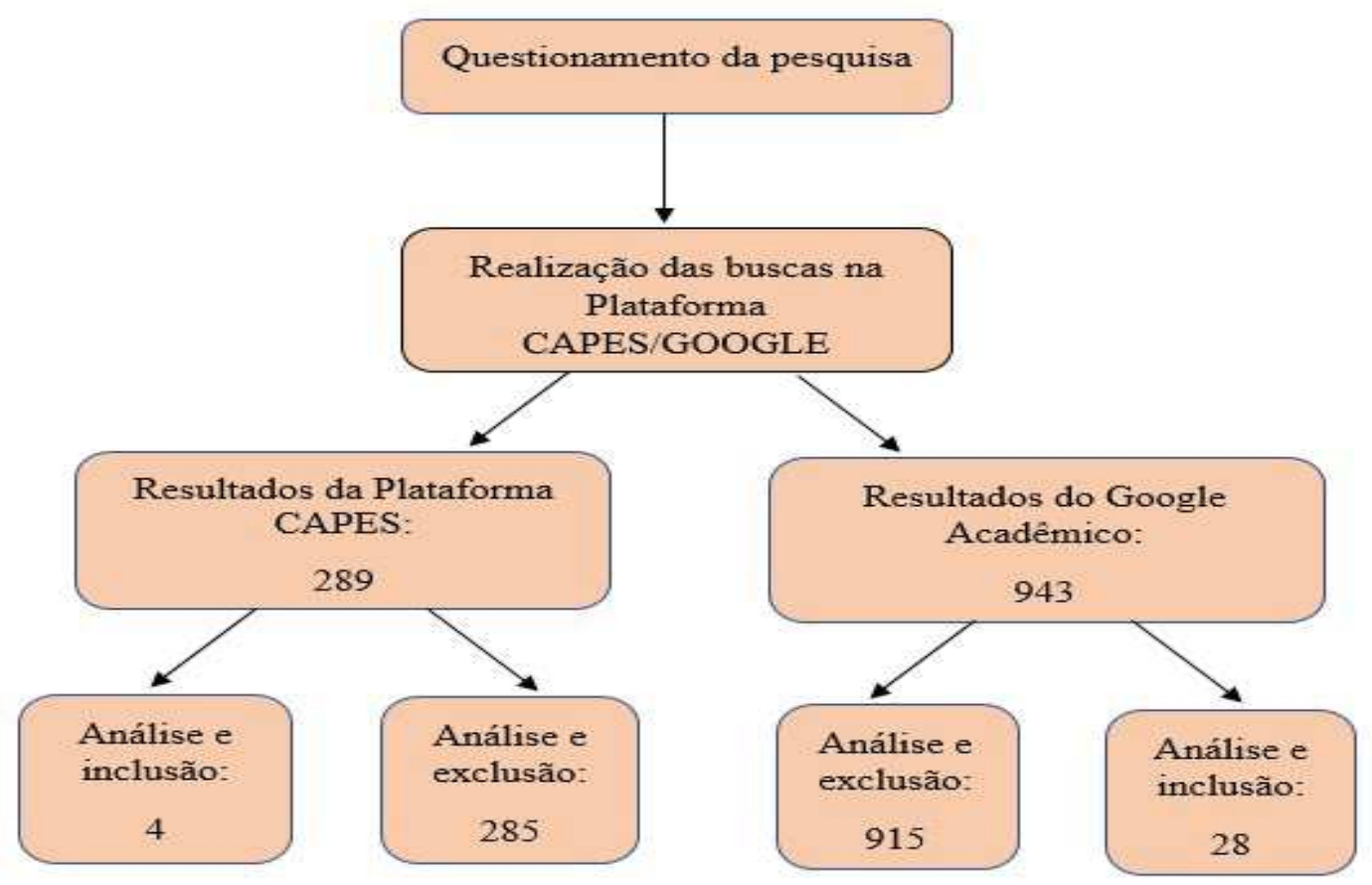

Fonte: elaborado pela autora (2020). 
Para a extração de dados foi preenchido um quadro inicial com informações sobre título, ano de publicação, revista, autor, objetivos, metodologia, principais resultados e conclusão com os possíveis artigos para seleção. Em seguida, foi realizada a leitura completa dos textos selecionados e foram examinados de acordo com os critérios de inclusão estabelecidos e selecionados os artigos para compor a revisão.

Os artigos selecionados foram descritos de acordo com a experiência relatada pelo autor no uso de hortas escolares como ferramenta de ensino, limitações na construção e potencialidades das mesmas para o ensino de biologia no ensino médio.

Após a revisão sistemática foi produzido um manual de aulas práticas utilizando hortas escolares como ferramentas no ensino de biologia, que constitui o produto desta dissertação de mestrado (Anexo 1). 


\section{RESULTADOS E DISCUSSÃO}

Na busca realizada no Portal de Periódicos da CAPES e Google acadêmico foram encontrados um total de 1.232 trabalhos. Destes, foram selecionados 32 que atendiam aos critérios de elegibilidade, sendo que 1.200 trabalhos não estavam relacionados diretamente ao tema da pesquisa. De acordo com os critérios de inclusão, somente trabalhos que descreviam experiências com hortas escolares envolvendo alunos do ensino médio e que colaborassem para o ensino de Biologia, compuseram a amostra. Em relação aos artigos selecionados na base de dados Google acadêmico, foram selecionados inicialmente 39 artigos que quando analisados mais detidamente foram excluídos 11 conforme descrição no Quadro 2.

Quadro 2 - Artigos excluídos da base Google acadêmico com respectivos motivos

\begin{tabular}{|c|l|}
\hline $\begin{array}{c}\text { Número total de artigos } \\
\text { excluídos: 11 }\end{array}$ & Motivo \\
\hline 2 & Selecionados na busca periódicos capes - em repetição \\
\hline 2 & Exp repetição no Google acadêmico \\
\hline 2 & Relato de experiência \\
\hline 1 & Experiência apenas com plantas medicinais \\
\hline 1 & Dissertação sobre implantação de horta urbana \\
\hline 1 & Relatos de projetos não concluídos \\
\hline 2 &
\end{tabular}

Fonte: elaborado pela autora (2020).

O Quadro 3 apresenta uma descrição dos trabalhos selecionados nas bases de dados CAPES e Google acadêmico em relação ao ano de publicação, autor, título e periódico

ou

local

publicado. 


\section{Quadro 3 - Descrição dos artigos selecionados}

\begin{tabular}{|c|c|c|c|}
\hline Ano de publicação & Autor & Título do artigo ou trabalho & Periódico ou local publicado \\
\hline 2011 & $\begin{array}{l}\text { CRUZ-SILVA, C. T. A DA.; } \\
\text { MUNARETTO, F.C.; } \\
\text { MANTOVANI, T. }\end{array}$ & $\begin{array}{l}\text { Viabilidade da utilização da horta da } \\
\text { escola como laboratório para ensino de } \\
\text { Ciências e Biologia. }\end{array}$ & Revista Didática Sistêmica, v.13, n.1, p. 51 \\
\hline 2013 & $\begin{array}{l}\text { BORGES, L.L.; DE FREITAS, } \\
\text { P. H.; SILVA, R. A. O. }\end{array}$ & $\begin{array}{l}\text { Horta escolar recurso para se discutir a } \\
\text { Educação Ambiental. }\end{array}$ & Anais da Semana de Licenciatura, Jataí, GO, p. 13-18 \\
\hline 2013 & CABRAL, M.M.; SOUZA, M. S. & $\begin{array}{l}\text { Projeto de horta escolar: estudo de caso } \\
\text { no colégio da Polícia Militar de Rio } \\
\text { Verde - GO. }\end{array}$ & $\begin{array}{l}\text { Revista Eletrônica do curso de Pedagogia do Campus Jataí - UFG, } \\
\text { v.1, n.14 }\end{array}$ \\
\hline 2014 & BRITO, J. L. & $\begin{array}{l}\text { O uso da metodologia de projetos como } \\
\text { instrumento de Educação Ambiental: } \\
\text { uma experiência no Colégio Manoel de } \\
\text { Jesus }\end{array}$ & $\begin{array}{l}\text { Trabalho de Conclusão de Curso (Especialização) - Universidade } \\
\text { Tecnológica Federal do Paraná, Medianeira }\end{array}$ \\
\hline 2014 & FONSECA, G., 2014a & $\begin{array}{l}\text { Hortas Agroecológicas: Ecologia e } \\
\text { Gestão Ambiental na Escola. }\end{array}$ & VirtualBooks Editora, Edição 2014, p.60 \\
\hline 2014 & FONSECA, G., 2014b & $\begin{array}{l}\text { Percepções dos estudantes do curso } \\
\text { técnico em administração integrado ao } \\
\text { Ensino Médio sobre o uso de práticas } \\
\text { em agroecologia urbana no ensino de } \\
\text { Biologia e Gestão Ambiental. }\end{array}$ & $\begin{array}{l}\text { Revista Góndola, Enseñanza y Aprendizaje de las Ciencias; Vol. } 9 \text {, } \\
\text { n.2. p. } 79-96\end{array}$ \\
\hline 2014 & RESENDE et al & $\begin{array}{l}\text { A interdisciplinaridade por meio da } \\
\text { pedagogia de projetos: uma análise do } \\
\text { projeto "Horta escolar: aprenda } \\
\text { cultivando hortaliças" numa perspectiva } \\
\text { CTSA. }\end{array}$ & $\begin{array}{l}\text { Revista Eletrônica Debates em Educação Científica e Tecnológica, } \\
\text { v. } 4 \text {; n. } 1 \text {; p. 51-52 }\end{array}$ \\
\hline 2015 & $\begin{array}{l}\text { COSTA, C. A. G. DA; SOUZA, } \\
\text { J. T. A.; PEREIRA D. D. }\end{array}$ & $\begin{array}{l}\text { Horta escolar: alternativa para } \\
\text { promover educação ambiental e } \\
\text { desenvolvimento sustentável no } \\
\text { Cariri Paraibano. }\end{array}$ & POLÊM!CA, Revista eletrônica da UERJ, [S.1.], v. 15, n. 3, p. 1-9 \\
\hline
\end{tabular}




\begin{tabular}{|c|c|c|c|}
\hline Ano de publicação & Autor & Título do artigo ou trabalho & Periódico ou local publicado \\
\hline 2015 & CUNHA, A.P. & $\begin{array}{l}\text { Projetos de hortas escolares e debate } \\
\text { agroecológico em Pernambuco no } \\
\text { contexto Latinoamericano. }\end{array}$ & $\begin{array}{l}\text { Giramundo, Revista de Geografia do Colégio Pedro II, v.2, n. 4, p. } \\
\text { 121-133 }\end{array}$ \\
\hline 2015 & DA SILVA, H. M. & $\begin{array}{l}\text { Implantação da horta escolar na escola } \\
\text { Santo Afonso. }\end{array}$ & $\begin{array}{l}\text { TCC (Licenciatura em Química) - Universidade Federal do Ceará, } \\
\text { Fortaleza, }\end{array}$ \\
\hline 2015 & FIOROTTI et al & $\begin{array}{l}\text { Horta: a importância no } \\
\text { desenvolvimento escolar. }\end{array}$ & $\begin{array}{l}\text { Anais...XIV Encontro Latino-Americano de Iniciação Científica, } \\
\text { p.7 }\end{array}$ \\
\hline 2015 & MEDEIROS et al & $\begin{array}{l}\text { Análise e diagnóstico de projetos de } \\
\text { implantação e implementação de hortas } \\
\text { caseiras em escolas. }\end{array}$ & Revista Integralização Universitária. Palmas -TO, v.10, n.13 \\
\hline 2015 & SILVA et al & $\begin{array}{l}\text { Hortas escolares: possibilidades de } \\
\text { anunciar e denunciar invisibilidades nas } \\
\text { práticas educativas sobre alimentação e } \\
\text { saúde. }\end{array}$ & Revista de Educação em Ciência e Tecnologia, v.8, n.1, p.265-288, \\
\hline 2015 & $\begin{array}{l}\text { SILVA, A. C. D. ; SOUZA, A. } \\
\text { A. e NASCIMENTO, C. R. }\end{array}$ & $\begin{array}{l}\text { Horta na escola: sustentabilidade e } \\
\text { hábitos saudáveis no município de } \\
\text { Cantá-RR. }\end{array}$ & Revista Atas de Saúde Ambiental, v. 2, n.3, p. 80-89 \\
\hline 2015 & $\begin{array}{l}\text { TERRA, S. B.; MATTIA, J. L. } \\
\text { DE; JASKULSK, G. F. }\end{array}$ & $\begin{array}{l}\text { Produção de hortaliças orgânicas na } \\
\text { escola: promoção de hábitos } \\
\text { saudáveis e o cuidado com meio } \\
\text { ambiente. }\end{array}$ & Em Extensão, v. 14, n. 1, p. 52-75 \\
\hline 2015 & QUEIROGA, C. R. S. & $\begin{array}{l}\text { Implantação de horta agroecológica em } \\
\text { escola pública na cidade de São } \\
\text { Domingos - PB: Estudo de caso. }\end{array}$ & $\begin{array}{l}\text { (Dissertação de Mestrado Profissional), Programa de Pós-graduação } \\
\text { em Sistemas Agroindustriais, Centro de Ciências e Tecnologia } \\
\text { Agroalimentar, Universidade Federal de Campina Grande }\end{array}$ \\
\hline 2016 & BACCIOTTI, A. & $\begin{array}{l}\text { Produção de biodigestor e horta } \\
\text { orgânica como elemento integrador } \\
\text { entre escola e comunidade. }\end{array}$ & $\begin{array}{l}\text { Disponível em: < } \\
\text { http://hdl.handle.net/11449/137994 } \\
>\end{array}$ \\
\hline
\end{tabular}




\begin{tabular}{|c|c|c|c|}
\hline Ano de publicação & Autor & Título do artigo ou trabalho & Periódico ou local publicado \\
\hline 2016 & BARBOSA, G. R. & $\begin{array}{l}\text { Ensino e agroecologia: perspectiva a } \\
\text { partir da Escola Olimpya Angélica de } \\
\text { Lima. }\end{array}$ & Cadernos de Agroecologia, [S.l.], v. 10, n. 3 \\
\hline 2016 & BERNARDES et al & $\begin{array}{l}\text { Projeto horta na escola no período de } \\
\text { transição do colégio João XXIII para } \\
\text { CEPI João XXIII }\end{array}$ & Ciclo Revista, v.3, n.1 \\
\hline 2017 & NETO, J. S. & $\begin{array}{l}\text { Projeto horta na escola: ação } \\
\text { estratégica do PIBID Na formação } \\
\text { inicial do bolsista de Ciências }\end{array}$ & $\begin{array}{l}\text { Dissertação (mestrado) apresentada ao Programa de Pós-graduação } \\
\text { em Ensino de Ciências }\end{array}$ \\
\hline 2017 & OLIVEIRA e BALDINI & $\begin{array}{l}\text { Horta- Cultura popular e Ciência } \\
\text { identificação científica, propriedades e } \\
\text { usos: uma experiência no Ensino } \\
\text { Integral. }\end{array}$ & Revista Cerrados, v.15, n.1, p. 214-236. \\
\hline 2018 & ANSCHAU et al & Projeto Horta Viva na escola & $\begin{array}{l}\text { Ciência e Natura, Santa Maria v.40, Edição Especial: II mostra de } \\
\text { Projetos da UFSM - Campus Cachoeira do Sul, 2018, p. 148-155 }\end{array}$ \\
\hline 2018 & LEAL et al & $\begin{array}{l}\text { A horta como laboratório vivo para } \\
\text { trabalhar a interdisciplinaridade no } \\
\text { ensino médio }\end{array}$ & $\begin{array}{l}\text { Revista do Centro de Ciências Naturais e Exatas - UFSM, v.40, } \\
\text { Edição Especial: II mostra de Projetos da UFSM - Campus } \\
\text { Cachoeira do Sul, p. 243- } 248\end{array}$ \\
\hline 2018 & $\begin{array}{l}\text { MARCHÃO, M. S. G.; } \\
\text { MACHADO, P. F. L. }\end{array}$ & $\begin{array}{l}\text { Alfabetização científica na horta: } \\
\text { investigando a nutrição vegetal e o } \\
\text { fluxo da energia solar com alunos do } \\
\text { ensino médio }\end{array}$ & Indagatio Didactica, v.10, n.2 \\
\hline 2018 & $\begin{array}{l}\text { PRADO, E. W. DO; } \\
\text { MANSILLA, D. E. P. }\end{array}$ & $\begin{array}{l}\text { Demanda de ensino aprendizagem } \\
\text { apresentada por professores de Ciências } \\
\text { e Biologia da rede estadual no } \\
\text { município de Sorriso - MT }\end{array}$ & Revista Prática Docente, v. 3, n. 1, p. 196-207 \\
\hline
\end{tabular}




\begin{tabular}{|c|c|c|c|}
\hline Ano de publicação & Autor & Título do artigo ou trabalho & Periódico ou local publicado \\
\hline 2018 & SANTOS, C.O. & $\begin{array}{l}\text { Horta na escola: proposta pedagógica } \\
\text { numa escola do Cariri Paraibano }\end{array}$ & $\begin{array}{l}\text { (Trabalho de Conclusão de Curso - Artigo), Curso de } \\
\text { Especialização em Ciências da Natureza e Matemática para a } \\
\text { Convivência com o Semiárido, Centro de Desenvolvimento } \\
\text { Sustentável do Semiárido, Universidade Federal de Campina } \\
\text { Grande, Sumé - Paraíba - Brasil }\end{array}$ \\
\hline 2019 & $\begin{array}{l}\text { ARAÚJO, C. T. G. M.; } \\
\text { CABRAL, M. J. S.; JUST, J. }\end{array}$ & $\begin{array}{l}\text { Educação ambiental e a horta escolar } \\
\text { como elementos de melhorias para o } \\
\text { ensino médio articulado. }\end{array}$ & Revista Caribeña de Ciencias Sociales \\
\hline 2019 & BRITO, L. F. & $\begin{array}{l}\text { Educação ambiental e nutricional (ean) } \\
\text { :produção de horta orgânica como } \\
\text { prática pedagógica. }\end{array}$ & $\begin{array}{l}\text { Trabalho de Conclusão de Curso apresentado ao Curso de } \\
\text { Licenciatura em Biologia do Centro de Ciências Agrárias, } \\
\text { Ambientais e Biológicas (CCAAB) da Universidade Federal do } \\
\text { Recôncavo da Bahia (UFRB) }\end{array}$ \\
\hline 2019 & CARVALHO, M. C. & $\begin{array}{l}\text { A horta escolar como ferramenta } \\
\text { pedagógica no ensino de Biologia }\end{array}$ & $\begin{array}{l}\text { Dissertação (mestrado) - Universidade Estadual de Campinas, } \\
\text { Instituto de Biologia, Campinas, SP }\end{array}$ \\
\hline 2019 & $\begin{array}{l}\text { COSTA, A. S. V.; FERREIRA, } \\
\text { A. C. A. }\end{array}$ & $\begin{array}{l}\text { Horta escolar: instrumento para ensino- } \\
\text { aprendizagem alimentícia da Escola } \\
\text { Estadual Professora Antônia Silva } \\
\text { Santos, comunidade do Magazão Velho, } \\
\text { Magasão, Amapá }\end{array}$ & $\begin{array}{l}\text { Trabalho de Conclusão de Curso (Graduação em Educação do } \\
\text { Campo) - Campus de Mazagão, Universidade Federal do Amapá, } \\
\text { Mazagão }\end{array}$ \\
\hline 2019 & $\begin{array}{l}\text { RIBEIRO, D. C. A.; PASSOS, C. } \\
\text { G.; SALGADO, T. D. M. }\end{array}$ & $\begin{array}{l}\text { Horta escolar: uma alternativa } \\
\text { interdisciplinar para a Educação } \\
\text { ambiental e produção de alimentos sem } \\
\text { agrotóxicos }\end{array}$ & ANAIS do $5^{\circ}$ Simpósio sobre Sistemas Sustentáveis, v. 1, p.1537 \\
\hline 2019 & SILVA, T. M. S. & $\begin{array}{l}\text { Iniciação Científica com Projetos de } \\
\text { Botânica no Ensino Médio }\end{array}$ & $\begin{array}{l}\text { Dissertação (Mestrado Profissional em Ensino de Biologia em Rede } \\
\text { Nacional) - Instituto de Ciências Biológicas e da Saúde, Programa } \\
\text { de Pós Graduação em Ciências Biológicas e da Saúde, Universidade } \\
\text { Federal de Alagoas }\end{array}$ \\
\hline
\end{tabular}


A figura 3 apresenta uma relação dos artigos selecionados quanto ao tipo de publicação. Aproximadamente $72 \%$ dos trabalhos selecionados são artigos publicados em revistas e anais; $12,5 \%$ são dissertações de mestrados; $3 \%$ são monografias e $12,5 \%$ são Trabalhos de Conclusão de Curso (TCC).

Figura 3 - Relação dos artigos selecionados quanto ao tipo de publicação.

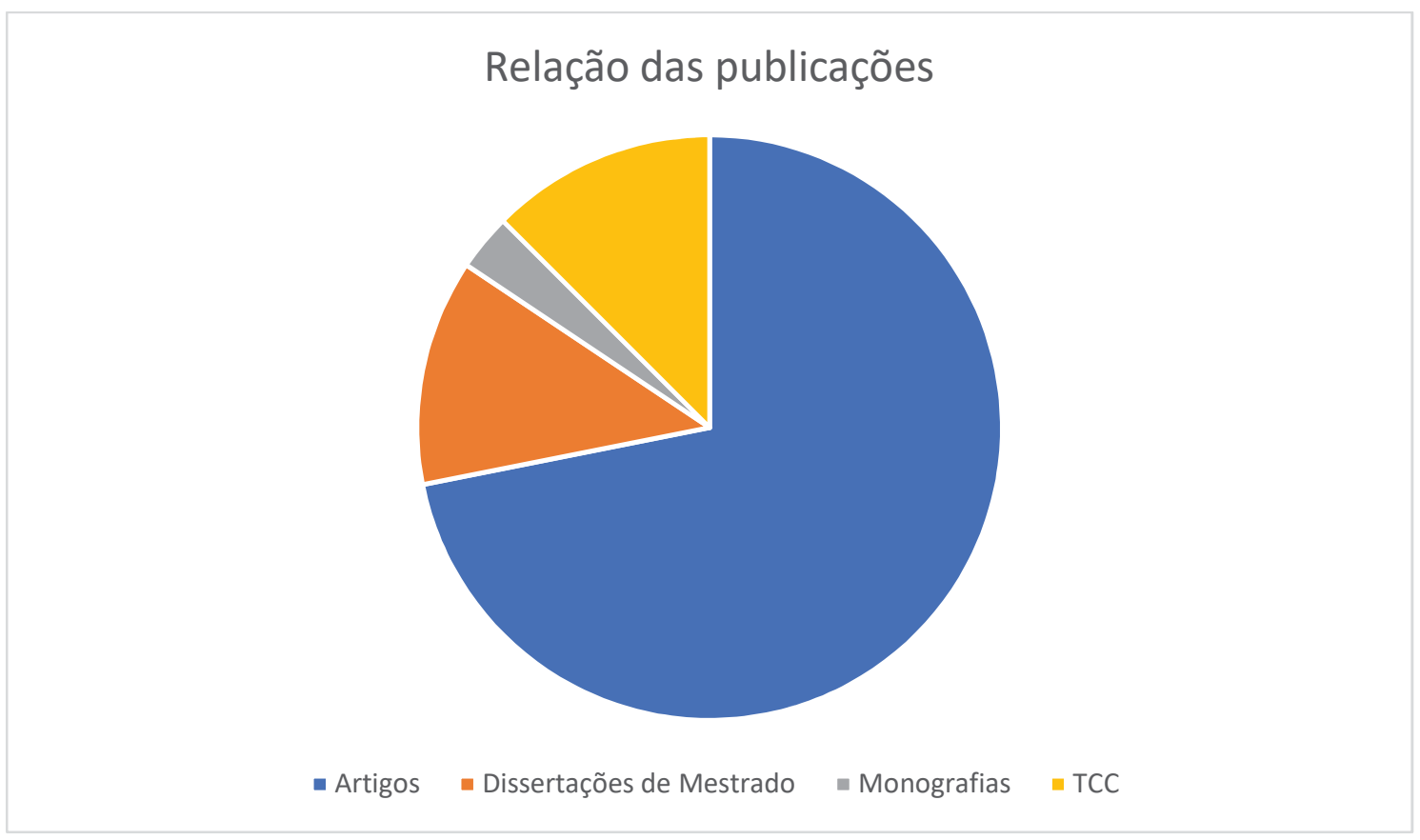

Fonte: elaborada pela autora (2020).

\subsection{DESCRIÇÃO DOS TRABALHOS SELECIONADOS}

Os trabalhos foram descritos e analisados com o objetivo de apontar as possibilidades de usar as hortas escolares como instrumento pedagógico de ensino e as dificuldades encontradas pelos professores ao utilizar este tipo de metodologia.

Em seus estudos, Fonseca (2014b) desenvolveu um projeto de horta escolar com alunos do Ensino Médio com a intenção de analisar a potencialidade do projeto para o estabelecimento da interdisciplinaridade e do trabalho em equipe na escola; a relação das atividades práticas na horta com a aprendizagem interdisciplinar de conhecimentos de Ecologia e Gestão Ambiental e analisar os valores humanos desenvolvidos nas atividades. O autor percebeu que o desenvolvimento das atividades com hortas escolares, tiveram impacto positivo sobre os alunos, promovendo o desenvolvimento cognitivo e pessoal, além de proporcionar um ambiente cooperativo de aprendizagem. 
Os alunos relataram que através da horta eles mantiveram um maior contato com a natureza e maior oportunidade de cuidar da escola, desta forma, eles contribuíram para o desenvolvimento do trabalho, fazendo sua divulgação por meio de diversos veículos de comunicação, tais como, visitas a outras salas e divulgação nas mídias digitais. Também demonstraram domínio nos temas pertinentes a Agroecologia, como o cultivo orgânico, assimilando seus conhecimentos ás práticas desenvolvidas na horta escolar. $\mathrm{Na}$ percepção dos alunos o projeto permitiu desenvolver na prática, os conteúdos de Biologia e Gestão Ambiental, sendo que em suas observações, eles descreveram conceitos relacionados a Revolução Verde, ao Desenvolvimento Sustentável, aos Ciclos Biogeoquímicos, relações ecológicas na natureza, impactos ambientais e botânica. Fonseca (2014b) afirma que a implantação de um projeto interdisciplinar exige muito trabalho e dedicação e para que flua é de extrema importância estabelecer parcerias e envolver um maior número possível de jovens de diferentes faixas etárias. Para o autor, trabalhar a agroecologia de forma interdisciplinar, contribui para a formação de cidadãos críticos, estabelecendo uma conexão entre conhecimento científico e valores morais. Desta forma, notamos que o uso da horta escolar como ferramenta pedagógica contribui significativamente para o desenvolvimento de temas relacionados ao Ensino de Biologia, ampliando os campos de ensino do professor, levando a Biologia para além da sala de aula, além de ter caráter interdisciplinar (SILVA et al, 2015).

Cunha (2015) apresenta em seus estudos uma revisão bibliográfica de experiências com hortas escolares em países da América Latina e Caribe após os anos 2000 e também descreve as repercussões de um projeto de horta escolar com alunos do $1^{\circ}$ e $2^{\circ}$ ano do ensino médio. A partir do levantamento bibliográfico, Cunha (2015) identificou a presença de hortas escolares em quase todos os países latino-americanos e que o tema ganhou maior projeção após os anos 2000, também observou que todas as experiências com hortas são norteadas por princípios agroecológicos. Nesse contexto, podemos concluir que, o tema horta escolar, ganhou maior relevância após o surgimento do movimento agroecológico, na década de 70, mas só ganhou força a partir dos anos 2000 (PAULINO e GOMES, 2019). Em sua experiência com horta escolar como laboratório vivo, Cunha (2015) observou que as atividades despertaram maior interesse dos alunos em participar das aulas, inclusive os alunos mais dispersos; permitiram a dinamização do processo de ensino-aprendizagem; estimularam o trabalho cooperado e 
solidário; proporcionaram uma observação mais atenta dos ciclos naturais e conscientizaram os alunos sobre os benefícios do cultivo ecológico, estimulando-os a reproduzirem a prática em suas casas. O autor afirma que a inserção do debate agroecológico e de hortas escolares como políticas públicas da educação poderiam fortalecer os campos da saúde, agricultura e educação através de práticas inter/multidisciplinares no processo de ensino-aprendizagem que promovam a ampliação da consciência e ações ecológicas, sobre os riscos do uso de agrotóxicos e o estimulo ao consumo de alimentos saudáveis, além de contribuírem para a inserção transversal da agroecologia na educação básica.

Silva et al (2015) fizeram uma análise textual discursiva, cujo corpo da investigação, foi formado por relatos de experiências com hortas escolares de diferentes regiões do Brasil dividido em dois conjuntos, o primeiro, composto por formulários com descrições de experiências com hortas escolares e o segundo foi composto por registros de uma experiência com horta ecológica construída a partir de pesquisas e ações anteriores sobre o tema. Os autores fizeram uma crítica sobre as experiências com hortas escolares, afirmando que embora a horta escolar seja utilizada como recurso para atender objetivos relacionados às questões ambientais, assim como de alimentação e saúde pode, além de não proporcionar avanço nas discussões correlatas, reforçar práticas consideradas inadequadas. Através da análise de experiências com hortas escolares o autor observa que não há uma preocupação em relação aos aspectos ergonômicos ou utensílios utilizados pelos estudantes, visando a segurança individual e coletiva, além disso, não são usados EPI's (Equipamento de proteção individual) que garantam a segurança dos estudantes, negligências estas que também são observadas no trabalho dos agricultores rurais. Os autores também questionam quanto a escolha do adubo orgânico utilizado no cultivo, de procedência muitas vezes desconhecida e que poderá ocasionar a contaminação da horta e dos estudantes. Assim como a escolha de sementes, que são compradas em lojas agrícolas e não são observadas as instruções de manuseio, apenas o fácil acesso, podendo provocar intoxicações nos indivíduos que as manuseiam. Outra negligência apontada pelo autor é o uso de materiais como garrafas pet na confecção de hortas escolares, seriam estes materiais adequados? A utilização destes materiais, contribuem para o cultivo agroecológico? Os autores concluíram que para a promoção da alimentação saudável e adequada é necessária elaboração de 
orientações adequadas para as ações nas hortas escolares. Não há receitas para identificar aspectos ausentes no cotidiano e para práticas pedagógicas, entretanto, há indicações para iniciar essa caminhada e a partir de então, construir os próprios caminhos.

Oliveira e Baldini (2017) produziram, durante a disciplina eletiva "Horta, Cultura Popular e Ciência", uma horta de temperos, ervas medicinais e hortaliças, incentivando os alunos em projetos de vida voltados principalmente para Nutrição, Engenharia de alimentos, Culinária, Gastronomia, Biologia, Geografia e correlatos. Os trinta e nove alunos participantes do projeto foram divididos em grupos de trabalhos práticos para a construção da horta. Paralelamente às aulas práticas os alunos receberam também instruções teóricas sobre o cultivo de hortas e um dos principais objetivos foi fazer a identificação científica das espécies cultivadas na horta. Os alunos também receberam instruções de como reaproveitar os alimentos e prepararam receitas que auxiliam no combate ao desperdício de alimento, seguindo a cartilha "Aproveitamento Integral dos alimentos". Através do projeto os alunos fizeram a identificação científica das plantas cultivadas na horta e elaboraram um livro de receitas com alimentos produzidos na própria horta, atividades estas que podem ser contextualizadas ao Ensino de Biologia para trabalhar os conteúdos de nomenclatura científica e nutrição. Os autores perceberam que a prática com hortas escolares permitiu aos alunos e demais envolvidos uma aproximação com a natureza, proporcionou um convívio coletivo e conscientização em relação ao meio ambiente. Eles evidenciaram que as hortas constituem um objeto de estudo interdisciplinar, através do qual são discutidos temas sobre alimentação, nutrição, questões ambientais, entre outros e salientaram que ter uma disciplina destinada apenas ao desenvolvimento do projeto, colabora para colocar em prática o projeto horta escolar.

Fiorotti et al. (2015) realizaram um estudo de caso de um projeto de horta escolar desenvolvido através da matéria de educação ambiental com alunos do curso técnico em meio ambiente, cujo objetivo era minimizar os gastos da escola com a merenda escolar. A fim de compreender a importância da horta na escola sob o ponto de vista dos alunos e equipe pedagógica, foi aplicado um questionário semiestruturado a um total de 176 entrevistados. Os questionários foram respondidos pelos professores, funcionários e alunos do Ensino médio. Os autores observaram que o projeto 
desenvolvido possibilitou o contato direto dos alunos com o solo e permitiu conhecer e associar os ciclos alimentares de semeadura, plantio e cultivo. Através da análise dos resultados dos questionários os autores observaram que os entrevistados consideram a horta escolar um projeto de grande relevância uma vez que permite um maior contato com o solo, trabalho em equipe e contribuem para uma alimentação saudável. No entanto ao questionar sobre o interesse dos entrevistados em participar do projeto, $53 \%$ disseram não ter disponibilidade para participar do mesmo e alguns entrevistados desconheciam a existência de uma horta na escola. Os autores concluíram que pode haver uma conciliação entre economia e meio ambiente através da prática com hortas, uma vez que a mesma contribui para o beneficiamento do solo, ar, economia e saúde dos alunos, no entanto, salientam que existe pouco interesse por parte dos alunos e funcionários em participar do projeto. Os autores também atentam para o fato da produção da horta não suprir as necessidades da merenda escolar, apenas contribui para minimizar os gastos.

Silva, Souza e Nascimento (2015) realizaram um estudo de caso de um projeto de horta escolar desenvolvido com alunos (entre 15 e 65 anos) que manifestaram interesse em participar do curso "Produção de Olerícolas". A atividade foi dividida em aulas teóricas e práticas. As aulas contemplaram os temas: origem dos alimentos, importância da alimentação saudável, técnicas para construção da horta, manejo das culturas, nutrientes do solo, luminosidade, temperatura, fotossíntese, desenvolvimento de plantas, tipos de raízes e tubérculos, tipos de solo, geometria plana, dentre outras atividades educativas. Para avaliar o projeto, os autores aplicaram um questionário aos participantes, antes e depois da realização do projeto. Os autores afirmam que os alunos do curso tiveram um papel muito importante no desenvolvimento da horta na escola, e que o trabalho em equipe permitiu produzir produtos de maior qualidade. $\mathrm{O}$ trabalho com a horta escolar contribuiu para a sensibilizar os alunos no que diz respeito a preservação do meio ambiente a partir da produção de alimentos sem uso de agrotóxicos, estimulou o respeito a pluralidade e diversidade cultural fortalecendo a ação coletiva e organizada.

Anschau et al. (2018) descrevem em seu estudo o desenvolvimento do projeto de extensão intitulado "Horta viva na escola", com objetivo de implantar horta em escolas e através delas, desenvolver hábitos saudáveis e consciência socioambiental junto aos 
participantes. As escolas participantes atendiam turmas de educação infantil, ensino fundamental e ensino médio. A horta produzida através do projeto foi utilizada para produzir os alimentos consumidos na merenda escolar e possibilitou o desenvolvimento de aulas práticas e projetos interdisciplinares. Segundo os autores, a realização do projeto proporcionou aos participantes uma nova ideia de alimentação saudável e de sustentabilidade em pequenos espaços e contribuíram para a formação de sujeitos mais conscientes que levam para a vida ensinamentos ambientais, sociais e de sustentabilidade.

Costa, Souza e Pereira (2015) realizaram um estudo de caso com 56 alunos do ensino médio no município de Gurjão/Paraíba, os autores escolheram a horta como instrumento pedagógico pois o município é constituído na sua maioria por uma população rural. A proposta destaca a inserção da educação ambiental por meio da implantação da horta, pela qual pode-se trabalhar alternativas de manejo de solo-água, a importância das hortaliças na alimentação, técnicas de produção, o trabalho cooperado e participativo, e a reciclagem - pois os canteiros foram confeccionados com garrafas Pet. Antes de colocar em prática a construção da horta, os alunos realizaram pesquisas de caráter investigativo sobre as hortaliças, recursos hídricos, solo e técnicas de manejo. Segundo os autores, a implantação da horta incentivou um comportamento diferente dos alunos, contribuindo para a formação de um espírito cooperativo e participativo através dos trabalhos em grupo, os mesmos despertaram interesse em temas relacionados a: problemas ambientais, o uso dos recursos hídricos de forma correta, a importância da reciclagem e a importância das hortaliças para a alimentação humana e qualidade de vida. Para Costa, Souza e Pereira (2015) o projeto horta na escola permite trabalhar a educação ambiental de forma interdisciplinar, contribuindo para uma melhoria no processo ensino-aprendizagem, fortalecendo a temática de desenvolvimento sustentável e estimulando a reprodução dos saberes adquiridos pelos alunos em suas residências.

Santos (2018) realizou um estudo de caso do projeto "Horta na escola" desenvolvido com alunos do $9^{\circ}$ ano do Ensino Fundamental e $1^{\circ}, 2^{\circ}$ e $3^{\circ}$ ano do Ensino Médio. Com a proposta de contextualizar e dinamizar as aulas de Biologia e Ciências o projeto contou com aulas expositivas, estudos teóricos, realização de palestras; aulas de campo para contextualização dos conteúdos de sala aula com o universo da região e socialização das ações junto a comunidade local. O projeto foi desenvolvido de forma 
conjunta, e através da discussão de temas relativos ao plano de aula de Biologia, foram trabalhadas abordagens de caráter interdisciplinar, desse modo o projeto contribuiu não somente para ao ensino de Biologia, mas também contribuiu para o desenvolvimento de habilidades na Língua Portuguesa, Matemática e Geografia, através da discussão de temas como: questões ambientais, saúde, convivência com o meio ambiente e uso racional da água, técnicas de produção de mudas e de cultivo, estudo do solo, defensivos agrícolas naturais, agrotóxicos e a saúde humana e alimentação saudável. Segundo os professores, as atividades contribuíram em suas práticas docentes, despertando o senso crítico e permitindo a conexão de vários conteúdos ministrados em sala de aula, trazendo-os para a prática e despertando valores no que se refere à proteção do meio ambiente, como também a uma nova consciência alimentar. Os estudantes que participaram da pesquisa relataram a importância dessas atividades e a necessidade de ampliar projetos para que haja maior participação dos discentes e sensibilização para as questões ambientais. Para o autor é evidente a grande eficácia da manutenção de hortas nas instituições de ensino, pois além de contribuírem para o desenvolvimento cognitivo do aluno, contribuem para o seu desenvolvimento pessoal.

Bernardes et al (2016) apresentam um estudo de caso do projeto Horta na Escola em sua criação no ano de 2015 no então Colégio Estadual João XXIII e da evolução do projeto à uma disciplina eletiva ofertada no ano de 2017 no atual CEPI João XXIII, relatando as mudanças ocorridas e vivenciadas pelo grupo do PIBID Interdisciplinar (subprojeto Biologia e Química). O projeto possibilitou a realização de atividades num espaço não formal onde foram realizadas aulas práticas que permitiram a observação de mecanismos de transporte e ação dos nutrientes, educação ambiental, relações tróficas, entre outros, além da produção de alimentos saudáveis que foram oferecidos na merenda escolar, contribuindo para economia dos gastos com merenda escolar. Durante o período de realização do projeto, a escola foi contemplada com a implementação da Escola em Tempo Integral, e houve uma ampliação da carga horária escolar e consequente aumento na demanda de alimentos, a escola então concedeu um funcionário para auxiliar na manutenção da horta. O projeto que acontecia de forma interdisciplinar foi incorporado a uma Disciplina Eletiva chamada "Jardim que Alimenta o Corpo". Os autores concluíram que através da horta foi possível desenvolver uma série de estratégias lúdicas para ensinar sobre fisiologia vegetal, nutrição do solo e 
plantas, cadeia alimentar, alimentos orgânicos, aulas práticas no local e o próprio manejo da horta, e ressaltam que a união e apoio da comunidade foram fundamentais para a realização e manutenção do projeto.

Em sua dissertação de mestrado, Neto (2017) busca compreender as percepções dos bolsistas e coordenadores do Programa Institucional de Bolsa de Iniciação à Docência (PIBID), do curso de Ciências Biológicas da Universidade Federal do Ceará UFC, acerca das ações da temática Educação Ambiental desenvolvidas no Projeto Horta na escola, no universo escolar do ensino médio. O autor realizou uma análise de documentos, questionários e entrevistas semiestruturadas onde foram investigadas as concepções dos bolsistas sobre Meio Ambiente e EA (Educação Ambiental); ações e desafios vivenciados pelos bolsistas durante a implantação do Projeto Horta; relações entre a teoria e prática na construção de EA crítica; contribuições de Paulo Freire e Marcos Reigota para o desenvolvimento da EA crítica e por fim, as contribuições do PIBID à formação continuada dos coordenadores do programa, gestor e professor participante da escola e nos processos de ensino e aprendizagem, por meio da implantação da horta. O Projeto de Educação Ambiental, patrocinado pelo PIBID envolvendo a implantação da horta na escola, foi desenvolvido com a finalidade de oferecer novas estratégias no Ensino de Biologia, permitindo associar teoria e prática. Na realização das atividades da horta como ferramenta pedagógica de aprendizagem, foi utilizada a contextualização dos conteúdos relacionados às questões ambientais. Os bolsistas, em uma reunião com a equipe administrativa da escola e um professor responsável pelo projeto na escola, realizaram a escolha do local da horta e fizeram um cronograma de planejamento das atividades que iniciavam com aulas teóricas, onde eram desenvolvidos temas relacionados com a temática ambiental. Dentre as primeiras atividades relatadas pelos bolsistas, estão a construção de uma composteira, em seguida a semeadura. Os mesmos relataram que o uso da horta, como prática pedagógica alternativa, possibilitou um olhar diferenciado em relação ao papel pedagógico do professor e sobre a importância das relações interpessoais para a melhoria do ensinoaprendizagem. As hortas permitem a formação de uma consciência crítica ambiental e a promoção da interdisciplinaridade entre as diversas áreas de conhecimento. Alguns obstáculos e também aspectos positivos foram observados pelo autor. Alguns dos obstáculos foram falha no planejamento e abstenção do gestor da escola e os aspectos 
positivos foram na formação dos bolsistas e no desempenho de suas atividades na escola com a implantação da horta. O primeiro está relacionado com a percepção e na sensibilidade de visualizar o potencial dos seus alunos, não apenas restrito a sala de aula, mas, além dos muros da escola. O segundo está relacionado com os objetivos alcançados nas atividades desenvolvidas na horta, observado por meio do aumento no rendimento escolar dos alunos tidos como indisciplinados. A falta de consciência ambiental, segundo observações dos bolsistas, deve-se ao fato de ocorrer um déficit de práticas comunitárias baseadas na participação coletiva dos cidadãos em relação à gestão ambiental, pois muitas famílias que residem no local, não preservam o ambiente e essa realidade é repassada aos filhos destes, que por sua vez são alunos da escola. Segundo a gestão escolar, o PIBID estimulou a interação dos alunos, diminuiu a indisciplina, melhorou o rendimento das notas e também estimulou os professores a usarem novas alternativas pedagógicas em sua prática docente. Outra contribuição do PIBID está relacionada com abordagem dos conteúdos de forma contextualizada, favorecendo o entendimento dos conteúdos dados, por meio das atividades do Projeto Horta. O autor conclui que é possível melhorar a formação inicial do bolsista, por meio de práticas pedagógicas inovadoras, ou, com a implantação de projetos como a horta escolar, o que favorece dentre outras habilidades a reflexão crítica, melhora autoestima e a capacidade em agir de forma consciente e transformadora na sociedade.

Terra, Mattia e Jaskulski (2015) realizaram um estudo de caso de um projeto de extensão universitária, vinculado à Pró-Reitoria de Extensão (PROEX) da Universidade Estadual do Rio Grande do Sul (UERGS) executado no ano de 2013, em escolas estaduais do município de Bagé-RS, a intervenção contou com a participação de 79 pessoas, incluindo professores e alunos e intercalou aulas teóricas e atividades práticas objetivando incentivar os escolares a serem propagadores de conhecimentos e práticas relacionados ao meio ambiente em sua família, escola e comunidade. Nas aulas teóricas foram desenvolvidos conceitos relacionados ao cultivo orgânico, segurança alimentar, hábitos saudáveis e compostagem. O projeto de extensão possibilitou a interdisciplinaridade dos conteúdos relacionados a Biologia, a Educação Ambiental, a Agronomia, a Ecologia, a Nutrição e a Educação Física. O curso de extensão oportunizou a capacitação para a construção de hortas orgânicas e o debate agroecológico agregado a realização de práticas relacionadas com o meio ambiente. Os 
alunos dominaram satisfatoriamente, as técnicas de execução desenvolvidas através das atividades práticas e através desta proposta perceberam seu papel ecológico como sujeitos integrantes do ambiente em que vivem.

Resende et al. (2014) realizaram um estudo de caso de um projeto de horta escolar que objetivou o planejamento, execução e manutenção de uma horta com vistas à alfabetização científica numa perspectiva interdisciplinar. A implantação da horta foi dividida em três módulos: Planejamento, Execução e Plantio de Hortaliças e Manejo e Condução da Horta. Os Conteúdos das disciplinas de Matemática, Química, Biologia e Geografia foram desenvolvidos ao longo da implantação da horta obedecendo ao cronograma de atividades e seu contexto com o ensino em sala de aula. Nas aulas de Biologia foi discutida a importância do processo fotossintético, relacionando os fatores luz, oxigênio e gás carbônico, e da água para o desenvolvimento das plantas. Os alunos montaram tabelas com a porcentagem de água presente nas hortaliças cultivadas e trabalharam os ciclos do carbono, nitrogênio e oxigênio, estudaram também a propagação vegetativa e investigaram os fatores de crescimento das plantas e ciclo de cultivo. As atividades também contribuíram para o estudo da taxonomia através da identificação científica de espécies vegetais e animais encontradas na horta e permitiu abordar temas relacionados as relações ecológicas entre os seres vivos, controle biológico e características do solo. Os alunos também confeccionaram tabelas sobre a composição nutricional e medicinal das hortaliças cultivadas na horta. Neste contexto, o professor trabalhou com as questões de educação ambiental e alimentação, contaminantes de solo e preservação do meio ambiente, também foi possível trabalhar com aspectos quantitativos, com observação e análise, utilizando gráficos de desenvolvimento das plantas (frutos, folhas, caule, raízes, dentro outras). Segundo os autores os projetos com hortas escolares permitem a interdisciplinaridade e integração dos conteúdos estimulando a formação de uma consciência cidadã onde o aluno percebe-se como parte integrante do ambiente.

Costa, Ferreira e Viana (2019) objetivaram em seus estudos avaliar as contribuições educacionais do projeto horta na escola como instrumento de ensino aprendizagem e fonte alimentícia saudável à comunidade escolar. Essa pesquisa teve uma abordagem qualitativa desenvolvida em quatro etapas: $1^{\text {a }}$ - aplicação do questionário I para alunos e professora; $2^{\mathrm{a}}$ - ministração de aulas teóricas e práticas; $3^{\mathrm{a}}$ 
implantação da horta; $4^{\mathrm{a}}$ etapa: foi aplicado o questionário II aos mesmos participantes, finalizando-se a pesquisa. Participaram do projeto de construção da horta, 60 alunos do ensino fundamental e médio. Os resultados obtidos através da aplicação dos questionários permitiram concluir que muitos alunos detinham pouco conhecimento sobre hortas orgânicas e o desenvolvimento das atividades na horta escolar contribuíram para a compreensão de conceitos através de práticas educativas que permitiram trabalhar assuntos relacionados a produção orgânica, tais como a adubação orgânica, educação ambiental, alimentação saudável, dentre outros, além da valorização do trabalho coletivo para o sucesso da tarefa. Os autores relatam que o principal problema encontrado nas práticas com hortas escolares, não se refere a falta de conhecimento sobre as mesmas, mas ao fato dos alunos não relacionarem a horta na escola como uma prática que pode melhorar a qualidade de vida, como a mudança de hábitos alimentares, cuidado com o meio ambiente e o conceito de trabalho em equipe. As práticas desenvolvidas através da horta escolar, tiveram um impacto positivo sobre os alunos, os mesmos compreenderam a importância do método e sua contribuição para o processo ensino-aprendizagem. Através das hortas escolares o aluno é estimulado a buscar uma alimentação saudável e mudanças de hábitos; e ainda configura uma ferramenta educacional importante na construção do aprendizado, alicerçado ao conhecimento ministrado em sala de aula. O ensino das disciplinas de uma maneira diferenciada, por meio de aulas práticas e participativas, oportuniza uma aprendizagem motivadora com interação dos alunos nas atividades de preparação do solo, plantação e até colheita, podendo considerá-los como protagonistas deste processo de ensino e aprendizagem.

Cruz-Silva, Munaretto e Mantovani (2011) apresentaram uma apostila com roteiros de aula prática, a apostila foi confeccionada com base em pesquisas e revisão bibliográfica, onde foram selecionados os conteúdos que se enquadravam na possibilidade de serem desenvolvidos como aula prática utilizando a horta da escola. A apostila foi apresentada a vinte e três professores das disciplinas de Ciências e Biologia, de dez escolas públicas do município de Cascavel -PR, juntamente com um questionário estruturado com dez questões que os mesmos responderam expressando sua opinião em relação a apostila e o uso da horta como laboratório de ciências e biologia, integrando teoria e prática. Através da análise dos resultados do questionário, foram feitos os seguintes apontamentos: 
- $52,2 \%$ das escolas possuem hortas escolares;

- $83,3 \%$ dos professores destas escolas as utilizam para a realização de aulas práticas;

- Nas escolas que não possuem hortas, $69,8 \%$ dos professores demonstraram interesse na construção da mesma;

- $100 \%$ dos professores entrevistados demonstraram um grande interesse pela apostila apresentada pois acreditam que a utilização da horta como laboratório facilitará as aulas práticas com os alunos

- 95,65\% acreditam que a horta como laboratório de ciências e biologia é uma das maneiras de concretizar o aprendizado do aluno;

- $60,9 \%$ relataram que as escolas em que trabalham, a biblioteca não disponibiliza roteiros de aulas práticas, para facilitar o trabalho do professor na elaboração de atividades com hortas escolares;

- $91,3 \%$ deles relataram que a apostila facilitará a busca pela aula prática.

- $52,2 \%$ dos professores conseguem ter acesso a horta da escola ao passo que, $39,1 \%$ não tem acesso para levar os alunos, por não ter a horta no ambiente escolar ou pela escola não possibilitar essa oportunidade.

Diante dos resultados expostos pelos autores, nota-se que frequentemente, os professores não utilizam práticas com hortas escolares devido à falta de um material de apoio que possa orientá-los no desenvolvimento de tais práticas. Segundo os autores, a horta é fundamental dentro de uma escola, ela pode alicerçar as aulas de Ciências e Biologia, pois assumem a função de laboratório permitindo uma associação entre teoria e prática através da abordagem de diversos conteúdos pertinentes ao Ensino fundamental e médio, facilitando o aprendizado do aluno, além de fornecerem alimentos nutritivos que podem ser incrementados a merenda escolar.

Leal et al. (2018) realizaram um estudo de caso de um projeto de horta escolar, desenvolvido com 90 alunos do ensino médio e 15 funcionários e professores. Os voluntários desta pesquisa participaram de uma palestra com o tema "Importância das hortas escolares" e após iniciaram-se as atividades práticas de construção de uma horta escolar. Os participantes encontraram alguns obstáculos no desenvolvimento das atividades, como o desnivelamento do solo e grande número de resíduos e ervas daninhas no terreno destinado ao cultivo, problemas estes que foram resolvidos em 
parceria com a comunidade. A fim de orientar o trabalho dos professores foi realizado um encontro na escola para exemplificar possíveis atividades com hortas de caráter interdisciplinar. Foram discutidas as possibilidades de atividades relacionadas às áreas do conhecimento. A partir da implantação da horta, os autores observaram que a horta é uma ferramenta eficaz na formação integral do estudante, entretanto, é responsabilidade de todos que estão envolvidos no processo de aprendizagem, os alunos, os professores, a direção, os funcionários e a comunidade em geral. A implantação da horta estimula o aprendizado multidisciplinar dos alunos, além de estimular a consumir e produzir alimentos saudáveis, sem agrotóxicos.

Da Silva (2015) realizou um estudo de caso utilizando a horta escolar como laboratório vivo de Ciências e participaram das atividades, 22 alunos do ensino médio. Com objetivo de conhecer as concepções prévias dos alunos sobre horta foi aplicado um questionário semiestruturado, as respostas obtidas no questionário, foram analisadas pelos bolsistas e professores da escola e contribuíram para o nortear as ações a serem desenvolvidas no projeto. $\mathrm{O}$ trabalho então obedeceu as seguintes etapas: delimitação de um espaço para compostagem; debate de assuntos como os processos químicos, físicos e biológicos necessários para a decomposição da matéria orgânica, temas inseridos em seus conteúdos desenvolvidos em sala de aula determinado pela grade curricular da escola (propriedades químicas e físicas do solo; $\mathrm{pH}$; vegetais; técnicas de cultivo, produção de adubo orgânico e desequilíbrios ambientais); escolha das hortaliças a serem cultivadas e divisão dos trabalhos. O autor destaca que a horta é um excelente meio para potencializar o aprendizado do aluno, despertar seu interesse para a alimentação saudável e pelas questões ambientais, professores de todas as áreas podem trabalhar nas suas aulas a interdisciplinaridade e a contextualização, já que terão um laboratório vivo, explorando os mais variados temas. Através das hortas, pode-se realizar a interdisciplinaridade de conteúdos pertinentes a disciplina de Biologia e Química, utilizando práticas como as análises físico-químicas da água, adubação, correção de solo, orientar a elaboração de inseticidas e defensivos agrícolas naturais e desenvolver experimentos práticos tais como a detecção da presença de ferro no solo, determinação do $\mathrm{pH}$ e nutrientes nele encontrado. As atividades desenvolvidas nesse espaço possibilitaram desenvolver atitudes sustentáveis, reaproveitamento de alimentos para a adubagem, reutilização de materiais recicláveis como garrafas pet para a construção de 
vasos e canteiros, e sensibilização da comunidade escolar com relação a preservação do meio ambiente.

Marchão e Machado (2018) investigaram as concepções dos alunos sobre o desenvolvimento vegetal e o papel das plantas na manutenção da vida na terra, antes e após uma intervenção pedagógica, através de uma análise qualitativa de questionários e diálogos ocorridos ao longo de atividades que foram desenvolvidas na sala de aula e na horta escolar e da análise do diário de aula da professora. Inicialmente o estudo contava com a participação de 40 alunos do ensino médio, no entanto a análise de dados restringiu-se ao número de 10 alunos que participaram de todas as atividades. $\mathrm{Na}$ etapa exploratória, os autores observaram uma enorme desmotivação dos alunos em estudar Ciências sem aproximação de conceitos com a realidade dele, também notaram que os alunos tinham péssimos hábitos alimentares, mas um fator que contribui para a proposta de uma intervenção pedagógica utilizando uma horta escolar, foi o fato dos alunos demonstrarem interesse em desenvolver este tipo de atividade. Através de questionários, os autores investigaram o conhecimento dos alunos sobre as plantas e seu ciclo de vida, os mesmos concluíram que muitos estudantes não assimilavam bem os conteúdos ou detinham conceitos incoerentes, estas concepções equivocadas demonstraram a necessidade de uma intervenção pedagógica. Tal intervenção contou com 8 encontros com carga horária total de 13:30 horas, contando com aulas teóricas e práticas, partindo de uma abordagem investigativa. Através da horta escolar os alunos realizaram atividades experimentais que permitiram compreender as funções do solo, tipos de solo e importância da nutrição do solo, o ciclo da água, relevância da luz solar, diferença entre nutriente e alimentação vegetal e compostagem durante o preparo do solo da horta e o plantio de mudas. Ao finalizar a intervenção pedagógica, os alunos responderam novamente o questionário propostos pelos autores, e os mesmos concluíram que a intervenção pedagógica realizada obteve resultados positivos, mostrando a diminuição do número de equívocos relativos aos conceitos estudados. Os autores concluíram que as ações pedagógicas tendo a horta como eixo organizador, permitiram trabalhar conceitos científicos ligados ao desenvolvimento vegetal, ao fluxo de energia no ambiente, à educação ambiental, além de discutir situações cotidianas. E apontaram um caminho para o processo de alfabetização científica, que auxilia no desenvolvimento da 
capacidade de investigação e argumentação dos estudantes, contribuindo para um posicionamento mais crítico dos participantes no dia a dia.

Barbosa e Souza (2016) realizaram um estudo de caso das relações estabelecidas entre o cotidiano político, social, ambiental e cultural com as práticas curriculares levadas a cabo no ensino das escolas do campo no município de Goiás. A Escola Municipal Olympia Angélica de Lima realizou uma tentativa de discussão da agroecologia através da implantação, pela Escola Família Agrícola de Goiás (EFAGO), de uma horta agroecológica, no entanto o projeto não obteve grande sucesso, apesar dos alunos demonstrarem interesse em participar das atividades. Os autores observaram que as atividades desenvolvidas não tiveram conexão pedagógica com os conteúdos ministrados em sala de aula. Em alguns casos, os pais dos alunos, também proibiram seus filhos de trabalharem ainda que como atividade pedagógica, na horta agroecológica, fato que ocorreu devido falta de diálogo crítico entre escola $\mathrm{e}$ comunidade, impossibilitando desta forma, a construção de uma "escola agroecológica. A atividade mencionada, especificamente, permitiu diálogo inicial com os professores sobre as práticas agroecológicas. Os autores apontam para a necessidade de inserir conhecimentos históricos dos sujeitos do campo e seus familiares no processo educativo, principalmente em escolas do campo. Segundo os autores a inserção da agroecologia, numa perspectiva crítica é essencial para a transformação do ensino nas escolas do campo.

Queiroga (2015), realizou um estudo de caso, com a participação de 120 alunos e 4 professores do ensino médio, o objeto de estudo foi o projeto de implantação de horta agroecológica na escola pública de ensino médio no município de São DomingosPB. O projeto foi desenvolvido em 7 etapas:

1. Na primeira etapa ocorreu a mobilização de funcionários e alunos da escola;

2. Na segunda etapa foi aplicado um questionário de avaliação preliminar do local; análise do solo e água das cisternas, tipos de hortaliças a cultivar, delimitação da área para o cultivo;

3. Na terceira etapa houve coleta de amostras do solo e da água para análise;

4. Na quarta etapa ocorreu a preparação do solo para implantação da horta;

5. Na quinta etapa ocorreu a remoção de vegetais presentes no solo através da capina e a delimitação dos canteiros, nesta etapa também ocorreu a montagem 
de uma composteira com os resíduos da capina e que também passou a ser utilizada para descartar resíduos orgânicos da cozinha da escola;

6. Na sexta etapa ocorreu o plantio das hortaliças;

7. Na sétima etapa foi realizada a colheita.

O resultado dos questionários respondidos pelos participantes permitiu que autor fizesse algumas conclusões e apontamentos. Os integrantes afirmaram ser pertinente a implantação de uma horta na escola pois a mesma pode trazer diversas contribuições para a escola tais como: interdisciplinaridade, redução do custo da merenda, desperdício de água, compostagem e sustentabilidade. A comunidade também poderia se beneficiar pois os produtos excedentes poderiam ser comercializados na comunidade local, e os lucros poderiam ser investidos na horta escolar. Um dos problemas apontados pelos entrevistados é a disponibilidade de água na escola, pois a mesma dispõe de uma cisterna abastecida pela água da chuva, no entanto, nos períodos de seca, é abastecida por caminhões pipa e ou poços artesianos, e seu uso para irrigação pode gerar a contaminação das hortaliças e consequente contaminação da comunidade escolar. $\mathrm{O}$ autor também buscou averiguar os conhecimentos dos alunos sobre segurança alimentar e $70 \%$ dos entrevistados não sabiam sobre o que se referia, neste sentido o autor concluiu que os PCN (Parâmetros Curriculares Nacionais) não são explorados cotidianamente pela comunidade escolar. Também apontou que as atividades na horta escolar contribuíram para elevar a conscientização dos alunos sobre os problemas ambientais e permitiu a compreensão do que seja sustentabilidade. Os alunos perceberam a importância do uso das hortaliças como alimento saudável e modificaram o hábito alimentar após conduzirem as atividades na horta escolar e usufruírem das hortaliças na própria merenda.

Bacciotti (2016) realizou um estudo de caso que contou com a participação de 45 alunos do ensino médio onde foi desenvolvido um projeto de horta orgânica e de um Biodigestor. A pesquisa seguiu as seguintes etapas:

Etapa 1: os questionários Pré-teste;

Etapa 2: construção da horta orgânica e biodigestor;

Etapa 3: Atividades teóricas em sala de aula;

Etapa 4: os questionários Pós-teste;

Etapa 5: Apresentação para a comunidade. 
Como nosso objeto de estudo são experiências com hortas escolares, relataremos aqui, apenas resultados referentes a prática com horta escolar desenvolvida pelo autor, pois o mesmo, inclui em seu estudo o desenvolvimento de um projeto de biodigestor, cujos resultados foram desconsiderados na análise e descrição do artigo. Para a implantação da horta os alunos utilizaram um manual didático, oferecido pela escola, contendo instruções sobre como construir uma horta. Nas atividades realizadas em interdisciplinaridade com a horta escolar foi possível trabalhar temas relacionados "Produção de alimentos"; "Relações entre seres vivos" e "Relações dos seres vivos com o ambiente, agricultura orgânica, nutrientes fornecidos pela adubação, agrotóxicos e seus efeitos nocivos, controle biológico, nomenclatura biológica, processo de fotossíntese. Através da aplicação de questionários semiestruturados o autor avaliou o conhecimento de duas turmas e as contribuições que as práticas com horta escolar trouxeram, uma das turmas trabalhou os temas relatados anteriormente apenas em aulas teóricas, a outra turma trabalhou os temas através de práticas na horta escolar, o autor concluiu, através da análise dos questionários, que a na turma onde foi utilizada a horta escolar como ferramenta pedagógica de ensino, os alunos memorizaram e assimilaram melhor os conteúdos. Através dos resultados obtidos com o desenvolvimento do projeto o autor concluiu que o Ensino de Biologia com atividades práticas favorecem mais a construção do conhecimento científico do que apenas aulas teóricas do ensino tradicional, em que o aluno necessita memorizar aquilo que o professor diz em sala e não há reflexão diante do assunto.

Borges, Freitas e Silva (2013) analisaram o conhecimento dos alunos de ensino médio sobre educação ambiental e a percepção dos mesmos sobre o ambiente físico da escola, desde a horta, separação de lixo e a coleta seletiva. Para o desenvolvimento do trabalho, foram escolhidos aleatoriamente 30 alunos do Ensino Médio. Foi ministrada uma aula teórica sobre a percepção ambiental objetivando diagnosticar através do relato oral, o conhecimento dos alunos sobre Educação Ambiental e posteriormente foi aplicado um questionário aos alunos. $\mathrm{Na}$ aula teórica os autores observaram que alguns alunos têm consciência ambiental e outros não, os resultados dos questionários permitiram uma análise mais conclusiva, as respostas dos alunos revelaram que os mesmos consideram importante a construção de uma horta no ambiente escolar e que as mesmas podem ser construídas em espaços ociosos da escola e concordam que a 
ingestão de verduras contribuem para a nutrição humana. Quando perguntado se para a construção de uma horta escolar era necessário mão-de-obra especializada, uso de agrotóxico e alto investimento financeiro, todos os alunos responderam não ser necessário, pois todos poderiam participar na construção de uma horta, e esta estimularia a interação de alunos e professores. Analisando as respostas dos alunos os autores chegaram à conclusão que mesmo que o debate ambiental seja um tema de grande destaque na sociedade, muitos indivíduos ainda não desenvolveram essa consciente crítica sobre sua relação com o meio ambiente. Neste contexto, a horta mostra-se como uma alternativa de prática pedagógica, através da qual pode-se trabalhar a educação ambiental de uma maneira interdisciplinar, desde a preparação do espaço, produção de hortaliças e outros, bem como seu consumo por parte dos envolvidos, ou mesmo na obtenção de recursos financeiros.

Ribeiro, Passos e Salgado (2019) fizeram uma análise das percepções dos professores sobre a construção de uma horta escolar para trabalhar a Educação Ambiental e Produção de alimentos sem agrotóxicos. A pesquisa foi realizada com 12 professores da Escola Estadual de Ensino Fundamental no Estado do Piauí. Este estudo foi levado em consideração nesta revisão, pois permite reflexões sobre os profissionais do ensino de Ciências da natureza. Segundo os autores todos os docentes participantes da pesquisa consideraram que a construção da horta na escola foi fundamental para o desenvolvimento da Educação Ambiental da comunidade escolar e, alguns deles, perceberam que o trabalho na horta da escola também é capaz de incentivar hábitos alimentares saudáveis não somente nos alunos, mas em toda a comunidade escolar. Também contribuem para o ensino transversal da Educação Ambiental permitindo relacionar conceitos específicos de cada disciplina a práticas pedagógicas desenvolvidas dentro da horta escolar. Estas atividades permitiram os alunos perceberem a importância da alimentação saudável sem o uso dos agrotóxicos, considerando essas substâncias químicas perigosas para o meio ambiente e, consequentemente, para a saúde dos seres vivos, promovendo uma conscientização ambiental que ocorre de forma gradativa através do desenvolvimento do seu senso crítico a partir da análise de sua relação com a natureza. Os autores ressaltaram a importância da participação de toda a comunidade escolar na busca de soluções para diversos problemas ambientais, pois representam uma 
oportunidade para o desenvolvimento de habilidades relacionadas ao processo de construção da cidadania.

Carvalho (2019) popôs um modelo para a implantação de Horta Escolar, e sugeriu uma série de Sequências Didáticas de cunho investigativo, baseadas nas habilidades da BNCC (Base Nacional Curricular Comum), que poderão ser utilizadas como um instrumento de auxílio para o desenvolvimento de atividades práticas no Ensino de Biologia. Segundo o autor o projeto atingiu seu objetivo. O mesmo afirma que as atividades práticas com hortas escolares necessitam de um engajamento de funcionários e alunos para que possam ser realizadas e que as mesmas podem ser utilizadas para o ensino de outras disciplinas. O autor relata que os alunos participam ativamente da manutenção da horta e demonstraram orgulho do projeto, tirando fotos no local e as compartilhando em redes sociais. Notou-se também que a horta também foi um fator estimulador para diversas outras atividades na escola, como o plantio de mudas no entorno e interior da escola e reforma de jardins. No entanto o autor não garante que este trabalho permitiu o aprendizado de todas as habilidades sugeridas nas sequências didáticas, mas acredita que geram um estímulo na construção do conhecimento científico, aprimorando o raciocínio e a capacidade dos alunos em assimilar teoria à prática.

Cabral e Souza (2013) realizaram um estudo de caso da execução do projeto de horta escolar no Colégio da Polícia Militar de Rio Verde. Durante a execução do projeto foram produzidos 9 relatórios pela professora responsável pela execução do projeto, a mesma concluiu que o projeto oportunizou tanto para os alunos quanto para o professor um laboratório de buscas e aprendizagem com as informações e a prática, incentivandoos a valorizar mais o meio ambiente. Através das aulas de campo realizadas na horta, foi possível discutir conteúdos como agroecossistemas orgânicos e sustentáveis sem uso de agrotóxicos e inseticidas, tais como o combate dos parasitas com inseticidas naturais que foram produzidos pelos próprios alunos com o auxílio do professor. Os alunos que participaram efetivamente do projeto apresentaram melhora no comportamento e na relação com o professor, também demonstraram maior interesse pela natureza e valorização dos produtos naturais. No entanto, cabe ressaltar alguns pontos negativos no desenvolvimento do projeto, tais como a falta de motivação de alguns alunos e dos pais dos alunos na participação do projeto, o fato das atividades serem realizadas no 
contraturno e a distante localização da escola. Outras dificuldades também foram apontadas pela direção da escola como o combate as pragas e ervas daninhas e falta de comprometimento dos alunos. Neste contexto pode-se verificar que o trabalho teve um bom desenvolvimento, mas existe a necessidade de encontrar estratégias para resgatar a participação dos alunos, pois os mesmos demonstraram grande interesse nas atividades, no entanto, é necessário maior incentivo por parte dos professores, uma vez que somente uma professora utilizou a horta como ferramenta didática. Através da revisão de literatura, entrevistas e observação, os autores perceberam que o trabalho prático em uma horta permite resgatar nos alunos a consciência da importância de preservação do meio ambiente, levando-os a desenvolver trabalhos com materiais orgânicos, o que contribui para que haja uma melhoria na aprendizagem de disciplinas relacionadas ao tema, e dá subsídios também a outras disciplinas no desenvolvimento de atividades lúdicas.

Araújo, Cabral e Justi (2018) realizaram uma pesquisa-ação de um projeto de horta escolar com 340 alunos do ensino médio e 100 servidores. Participaram interdisciplinarmente, as disciplinas de Matemática, Química, Biologia e Língua Portuguesa, da unidade de ensino, desde a escolha do local até a colheita e consumo das hortaliças. Essa integração foi muito importante para o sucesso da proposta, uma vez que a horta necessita de cuidados diários. O cultivo da horta foi totalmente orgânico e para realizar o controle de pragas os alunos produziram inseticidas naturais e biodegradáveis no próprio laboratório da escola. Para levar os alunos a refletir sobre alimentação saudável, foi realizado um convite a todos os professores da Unidade Escolar para o aproveitamento dos recursos, conceitos científicos e sabedoria popular da horta a fim de promover aprendizagem ampla e significativa aos discentes da região. Dentre os trabalhos que foram realizados, os autores mencionaram, mesa redonda sobre "a alimentação fast food na contemporaneidade", um dia de alimentação saudável na escola, com saladas, a propagação de ensinamentos (visitas a escolas infantis para apresentar teatros educativos a respeito de hábitos alimentares saudáveis). Além disso, os alunos avaliaram dados calóricos dos alimentos produzidos na horta e produziram cálculos sobre a produção local. Em Biologia aprenderam e conheceram os diferentes grupos de plantas existentes, as características gerais das plantas, valor nutricional de cada hortaliça que foi cultivada, a atuação desses nutrientes em nosso organismo e as 
consequências do déficit de algum nutriente para o ser humano. A horta também foi utilizada para aprenderem a classificação biológica ou taxonomia, os alunos foram orientados a fotografar as plantas e fazer uma placa com a classificação e, assim, todos que fizeram parte da comunidade escolar ao fazer a leitura das placas conseguiam identificar o nome científico de cada planta. Diante deste contexto, percebe-se que o trabalho desenvolvido nesta escola foi muito enriquecedor e contou com a participação solidária de todos os alunos e professores. Os autores afirmam, que as atividades desenvolvidas contribuíram para a conscientização dos alunos do Ensino Médio acerca da temática ambiental levando-os a um interesse maior pelo conhecimento e pelas relações estabelecidas com o meio ambiente por meio das aulas práticas, compreendendo desta forma a necessidade de conservação dos ecossistemas, reaproveitamento de resíduos sólidos e a importância das hortaliças para a saúde humana além de estimular o desenvolvimento de valores comportamentais, trabalho em equipe, respeito e solidariedade.

Medeiros et al. (2015) realizaram uma pesquisa exploratória a partir da análise documental dos projetos de implantação de hortas escolares do Centro de Ensino Médio (CEM) Castro Alves e Escola Estadual Vila União, ambos localizados na região norte do município de Palmas, Tocantins. Ambos os projetos de hortas escolares tiveram como objetivo sensibilizar os alunos sobre a importância de se desenvolver hábitos alimentares saudáveis, além de enriquecer a merenda escolar com alimentos nutritivos e de qualidade. Através dos questionários os autores também concluíram que: a busca de parcerias no desenvolvimento de projetos com hortas escolares é uma grande preocupação das instituições; o uso da horta escolar como local de desenvolvimento de atividades extraclasse é um dos principais objetivos que se deve ter na elaboração de um projeto de horta escolar, pois é por meio da prática dessas atividades que os alunos desenvolvem hábitos ecológicos, podendo ser inseridos em algumas disciplinas, assuntos relacionados à educação ambiental; o cuidado com a horta é fundamental para que os alimentos cultivados possam ser saudáveis e apresentar qualidade; reconhecer que os alimentos oriundos da horta escolar são saudáveis é fundamental para a educação alimentar; a inserção dos alimentos produzidos na horta na alimentação dos alunos promove a sua reeducação alimentar; a horta escolar pode ser aberta e oferecida à comunidade como um todo, como pais de alunos, amigos da escola, vizinhos à escola e 
acadêmicos de graduações relacionadas a este tema. Os autores concluíram que as práticas com hortas escolares são ferramentas que impactam positivamente no ambiente escolar e devem ser estendidas as demais instituições de ensino.

Fonseca (2014a) realizou um estudo de caso de um projeto de horta escolar com 28 alunos do ensino médio em transversalidade a temas relacionados a agroecologia e como método de coleta de dados foram utilizados dois questionários abertos, um foi aplicado a equipe pedagógica e o outro foi aplicado em três momentos: após a conclusão dos temas relacionados a Ecologia; após a conclusão das bases tecnológicas Revolução verde e Desenvolvimento sustentável na disciplina Gestão Ambiental e após o estabelecimento inicial do projeto. Através da análise dos questionários foi possível analisar as percepções da equipe pedagógica e dos alunos em relação ao tema. A equipe pedagógica apresentou as seguintes percepções: a implementação de hortas agroecológicas contribui para o desenvolvimento cognitivo e pessoal dos alunos, a integração e a interdisciplinaridade; a equipe pedagógica possui conhecimento superficial sobre agroecologia e suas principais motivações para participarem do projeto é a possibilidade de desenvolvimento dos alunos. As percepções dos alunos são semelhantes às da equipe pedagógica: para os mesmos a implementação de hortas agroecológicas também contribuem para o desenvolvimento cognitivo e pessoal, a integração e a interdisciplinaridade, além do cuidado e embelezamento da escola; os alunos possuem conhecimento mais profundo sobre agroecologia; através das atividades desenvolvidas na horta existe uma maior possibilidade de contato com a natureza e de aplicar os conhecimentos na prática em outras oportunidades. Os alunos também apontaram algumas dificuldades, entre elas: a ausência da participação de outros professores, a falta de ferramentas e alguns materiais, a pouca participação de outros alunos. A grande maioria dos indivíduos relacionou as atividades práticas do projeto com as aulas teóricas de Gestão Ambiental e Biologia. Alguns relacionaram ainda o incremento de sua consciência ambiental e o aprendizado de conceitos de agroecologia. Os alunos também apresentaram de maneira equilibrada conceitos sobre: Revolução Verde, Desenvolvimento Sustentável, Manutenção da vida, fluxo de energia e matéria, Ecossistemas, populações e comunidades, Fatores associados aos problemas ambientais, Problemas ambientais contemporâneos, Fotossíntese e Botânica. A equipe pedagógica e alunos, concordam que a principal dificuldade do projeto foi em relação 
ao espaço limitado. Após a discussão dos resultados os autores concluíram que prática em uma horta agroecológica escolar, favorece a cognição de conceitos das ciências ambientais por oferecer a possibilidade de aplicação prática dos conceitos teóricos desenvolvidos em sala de aula, para que o projeto ocorra de forma interdisciplinar. $\mathrm{O}$ estabelecimento de um projeto interdisciplinar é necessário uma figura articuladora, que mobilize a equipe pedagógica e crie situações em que a interdisciplinaridade possa ocorrer. Neste contexto o estabelecimento de parcerias e a participação da universidade é fundamental para o êxito de projetos dessa natureza. Os autores salientam que o tratamento de um tema de relevância Sócio Ambiental como a Agroecologia, pode contribuir profundamente para a formação de cidadãos críticos, com embasamento cientifico, e com valores humanos raros em nossa época: humildade, compaixão e empatia.

Prado e Mansila (2018) realizaram uma abordagem qualitativa, por meio de entrevistas semiestruturadas destinadas aos professores de Biologia, com o objetivo de investigar as demandas para o ensino de Biologia, com ênfase no Ensino de Botânica. Participaram do estudo 21 professores de Biologia. Através da análise dos questionários sobre as percepções dos professores de Biologia, os resultados apontaram que os alunos têm maior dificuldade em compreender os conteúdos relacionados a Bioquímica, Genética e Botânica, as principais causas das dificuldades de aprendizado de conteúdos de Biologia foram o desinteresse dos alunos e a falta de relação dos conteúdos com a prática e lacunas na aprendizagem. Sobre as dificuldades em ensinar Biologia os professores apontaram que as principais dificuldades são a falta de laboratórios, seguida pela falta de material de apoio como guias didáticos e propostas de aula prática, mesmo nos livros didáticos. Os professores foram então questionados quanto a metodologia utilizada em suas aulas e sobre a frequência que instrumentalizam suas aulas, 18 professores informaram que suas aulas são expositivas e 15\% instrumentalizam suas aulas com frequência principalmente com uso de Datashow e slides, mas nenhum professor relatou usar aulas práticas. Apesar de todos concordarem com a afirmação de que as aulas práticas são muito importantes para o ensino de Biologia, nenhum dos professores entrevistados utilizam aulas práticas no ensino, alegando a falta de um laboratório na escola. Sobre a dificuldade dos alunos em aprender botânica os professores relataram que os mesmos têm dificuldade em assimilar conteúdos 
relacionados a botânica e escassez de material didático. Sobre o material didático, os pesquisadores pediram que os professores fornecessem sugestões de materiais e a maioria sugeriu a utilização de guias para aula de campo e manual de utilização de hortas. Os professores então foram questionados sobre uso de hortas escolares como ferramenta didática e a maioria afirmou nunca ter utilizado hortas como ferramenta de ensino, mas se mostraram dispostos a utilizar a prática caso houvesse um guia para direcionar o trabalho. Com base nos resultados obtidos na pesquisa, os autores confirmaram suas hipóteses sobre o ensino de Botânica e concluíram ser pertinente a elaboração de um guia prático para utilizar práticas com hortas escolares. A partir dos resultados obtidos com essa pesquisa os autores concluíram que:

- As disciplinas de Bioquímica, genética e Botânica apresentam os conteúdos com maior dificuldade de aprendizado pelos alunos;

- A dificuldade em aprender está diretamente relacionada ao desinteresse do aluno e à falta de conexão dos conteúdos com o cotidiano;

- A falta de laboratórios dificulta o uso de aulas práticas;

- Os professores raramente instrumentalizam o ensino de Ciências e Biologia;

- Aulas práticas, sequências didáticas e métodos ativos de ensino raramente são utilizados pelos professores.

Brito (2014) realizou um estudo de caso de projeto de horta escolar desenvolvido pelo professor de Biologia com 47 alunos do ensino médio. O projeto teve duração de 20 horas/aula e foi utilizado como instrumento pedagógico do $3^{\circ}$ bimestre. Os planos de aula elaborados pelo professor contemplavam os seguintes temas:

- A composição e a dinâmica formadora do solo;

- História da agricultura;

- A erosão e o manejo do solo;

- A utilização de fertilizantes na agricultura (químicos versus biológicos);

- Estratégias de controle químico e biológico de "pragas" e "doenças";

- O manejo das diversas culturas e hortaliças;

- A relação do homem com o alimento;

- Alimento e saúde. 
As ferramentas didáticas escolhidas para trabalhar os conteúdos descritos acima foram:

- Discussão de texto e exercício sobre a história da agricultura;

- Aula prática sobre permeabilidade do solo;

- Pesquisa sobre os horizontes do solo e fertilizantes;

- Debate sobre controle químico e biológico de "pragas" e "doenças";

- Resumo do documentário "O veneno está na mesa".

Após discussão dos assuntos, foi planejada uma horta escolar com base no Manual de Horta Orgânica Doméstica. A apresentação de um seminário foi a forma escolhida para idealização do projeto. Para isso as turmas foram divididas em cinco equipes, cada equipe elaborou uma apresentação sobre os seguintes temas:

Equipe 1: layout da horta e ferramentas;

Equipe 2: escolha de cultivos e compostagem;

Equipe 3: preparação do solo e disposição de canteiros;

Equipe 4: cuidando da horta: plantando, mantendo e colhendo;

Equipe 5: manejo básico: adubação e controle de "pragas" e "doenças".

Então foi aberto um diálogo onde os alunos idealizaram o projeto de horta escolar a ser colocado em prática. O professor avaliou o engajamento comportamental e cognitivo dos alunos antes, durante e depois do projeto desenvolvido. Através dos resultados e comparação das planilhas de engajamento comportamental e cognitivo o autor concluiu que os alunos mais assíduos (melhor engajamento comportamental) tiveram um melhor desenvolvimento cognitivo. Também observou que a prática com horta escolar contribui para o desenvolvimento cognitivo do aluno. $\mathrm{O}$ autor chegou à conclusão de que as atividades realizadas conseguiram alcançar o objetivo esperado, que foi o de criar um ambiente propício à formação de um conhecimento multidisciplinar e através desta ferramenta os alunos perceberam e desenvolveram competências sobre os valores e princípios de educação ambiental assim como construíram habilidades para resolver os dilemas de uma agricultura insustentável baseada na utilização de insumos químicos, excludente socialmente e degradadora dos ecossistemas terrestres. O projeto também promoveu a interdisciplinaridade com os conteúdos de história, química, geografia, geologia, os alunos compreenderam durante as aulas o valor de uma alimentação saudável, a relação entre os problemas ambientais e 
a forma como a agricultura moderna funciona, e acima de tudo a perspectiva de uma forma de viver integrada com os princípios da natureza.

Silva (2019) em sua dissertação de mestrado, avaliou o projeto de iniciação científica desenvolvido com 31 alunos do ensino médio associado a projetos de Botânica. Foi realizada uma pesquisa qualitativa dividida em etapas, em que no primeiro momento a professora fez um encontro com os alunos explicando para eles como ocorreria o projeto de iniciação científica, então alguns alunos foram selecionados e divididos em quatro grupos e cada grupo deveria trabalhar um tema relacionado ao ensino de Botânica. A escolha do tema foi realizada através de uma atividade lúdica chamada "tempestade de ideias", os temas escolhidos foram: carpoteca, plantas medicinais e tóxicas, horta suspensa e plantas ornamentais, duas alunas que não se identificaram com nenhum dos temas, tiveram a ideia de um quinto tema que era a divulgação científica dos projetos via internet através de um blog - "blog Biotânica". Os alunos deveriam pesquisar sobre os temas e desenvolvê-los na escola, também deveriam fazer visitas a famílias da comunidade para pesquisar sobre o tema e agregar conhecimentos. A professora também utilizou dois questionários semiestruturados diagnósticos no início da pesquisa e no final da pesquisa. Após a realização das pesquisas com orientação do professor os alunos desenvolveram os seguintes projetos:

- Carpoteca: os alunos fizeram uma coleta de frutos da região que seriam usados na carpoteca e fizera uma pesquisa bibliográfica no sentido de entender a morfologia dos frutos, importância econômica e nutricional e apresentaram o trabalho a comunidade,

- Plantas Medicinais e tóxicas: os alunos fizeram uma pesquisa na comunidade sobre plantas com propriedades medicinais e plantas tóxicas conhecidas pela população local e elaboraram uma cartilha informando sobre as características destas plantas e fizeram uma exsicata destas plantas para apresentar a comunidade. Os alunos também fizeram uma horta na escola com estas plantas que ficou conhecida como farmácia viva.

- Horta suspensa: os alunos fizeram hortas suspensas na escola e através desta técnica perceberam que se pode cultivar alimentos saudáveis em pequenos espaços, reproduzindo a técnica em suas casas. 
- Plantas ornamentais: os alunos fizeram pesquisas sobre plantas utilizadas na ornamentação das praças da cidade e criaram na escola um ambiente ornamentado com plantas

- Blog Biotânica: através do blog, foi divulgado via internet o trabalho dos demais alunos.

Através da análise dos questionários, o autor concluiu que antes de iniciar o projeto os alunos demonstravam pouco conhecimento e interesse na área de Botânica e no final do projeto demonstravam alto interesse e conhecimento na área. Em relação ao contato dos alunos com a Botânica fora da escola, no questionário aplicado no início do projeto afirmaram ter pouco contato com Botânica, mas ao final do projeto, eles perceberam que as plantas estão em toda parte e que tinham alto contato com Botânica. Os alunos também avaliaram a metodologia do projeto e quanto ao uso destas metodologias nas aulas de Biologia, a maioria dos alunos consideraram a metodologia muito boa e gostariam que fossem usadas estas metodologias nas aulas de Biologia. Silva (2019) concluiu que o uso de Metodologias Ativas é importante no ensino de Botânica e destacou os seguintes pontos positivos:

- Valorização das atividades individuais de cada indivíduo;

- Participação e interesse dos indivíduos envolvidos;

- $\quad$ Contextualização do conteúdo;

- Melhor interesse dos alunos pela Botânica.

Segundo a autora, alguns desafios também podem ser destacados, tais como a limitação de tempo, pois estes projetos necessitam de mais tempo para serem realizados e a dificuldade em acompanhar os alunos em todas as atividades de campo.

Brito (2019) realizou uma pesquisa de cunho qualitativo utilizando a metodologia da análise de Conteúdo Conceitual com aplicação de questionários, cujo objetivo foi discutir a temática da Educação Alimentar e Nutricional - EAN, na perspectiva da produção de horta orgânica como prática pedagógica. Nas atividades desenvolvidas foram abordadas as características que diferenciam alimentos orgânicos de não-orgânicos, a importância dos alimentos orgânicos para a saúde humana e animal e para o equilíbrio do meio ambiente, e os malefícios dos agrotóxicos nos alimentos. Os alunos também realizaram atividades através das quais fizeram a identificação e separação dos alimentos orgânicos dos não-orgânicos, construção de um terrário para 
uma prática experimental utilizando herbicida, construíram hortas verticais e horizontais com garrafas PET e também produziram um protótipo de irrigador para as hortaliças. Foram desenvolvidos temas como a erosão do solo e confeccionadas lixeiras de coleta seletiva. Através da análise dos questionários e da observação do desempenho dos alunos na realização das atividades o autor observou que o projeto horta na escola apresenta inúmeros benefícios permitindo um aprendizado significativo e pessoal do educando dentro dos parâmetros da Educação Ambiental. O projeto também oportuniza o trabalho interdisciplinar e transdisciplinar onde podem ser desenvolvidos temas que contemplam desde preservação do meio ambiente, desenvolvimento sustentável, até temas sociais como a distribuição de alimentos no planeta, a fome mundial, a importância das vitaminas e sais minerais advindos das hortaliças, as possibilidades de uso de plantas medicinais, o funcionamento do sistema digestório, dentre outros. Com a implantação da horta, foi possível fortalecer a interação entre professor e alunos, comunidade escolar, além de criar responsabilidades compartilhadas, já que esses, além de participarem do processo de construção, cuidavam de sua manutenção.

Considerando a horta como um laboratório vivo de aprendizagens, a maioria dos artigos descritos acima está em acordo com as diretrizes estabelecidas nos PCN que orientam para a produção de um conhecimento interdisciplinar e contextualizado. As Hortas na escola permitem a realização de atividades investigativas, pois, ao serem

utilizadas como ferramentas para a realização de atividades práticas, permitem a observação de dados e a utilização de linguagens para comunicar aos outros suas hipóteses e sínteses (SASSERON; 2011).

\subsection{POSSIBILIDADES E LIMITAÇÕES NO USO DE HORTAS ESCOLARES COMO FERRAMENTA DE ENSINO}

Todos os 32 artigos que fizeram parte deste estudo, apontam sobre as possibilidades do uso de hortas escolares como ferramentas de ensino, seja para o ensino transversal da educação ambiental ou para o ensino de Biologia. Apesar de nem todos os artigos relatarem experiências com hortas escolares no ensino de Biologia, os mesmos apontam possibilidades de se desenvolver o tema dentro da disciplina e também as dificuldades e desafios encontrados no desenvolvimento desta prática. Uma 
das dificuldades apontadas pelos professores de Biologia é a falta de tempo para desenvolver práticas com hortas escolares, Silva (2019) reforça esta observação em seus estudos. O professor de Biologia, geralmente dispõe de apenas duas aulas de 50 minutos semanais para o desenvolvimento de sua disciplina, e se não houver colaboração da comunidade escolar e/ou local na construção de uma horta, fica praticamente inviável para o professor o uso desta ferramenta de ensino. Nove, dentre os 32 artigos relacionados, relatam experiências com hortas escolares que foram desenvolvidas em disciplinas eletivas, curso de capacitação, projetos de extensão, através da disciplina de gestão ambiental, em atividade de intervenção pedagógica e no contraturno escolar. A partir desta análise, nota-se que o estabelecimento de parcerias para o desenvolvimento de projetos de hortas escolares é essencial para a realização dos mesmos (FONSECA, 2014a; MEDEIROS et al., 2015; SILVA et al., 2015; BERNARDES et al., 2016; NETO,2017; LEAL et al, 2018; PASSOS e SALGADO, 2019). Outro problema comum é a falha no planejamento das atividades e falta de material didático ou guias práticos e propostas de aulas práticas que orientem o professor no desenvolvimento de aulas práticas em hortas escolares (CRUZ-SILVA, MUNARETTO e MANTOVANI, 2011; NETO, 2017; PRADO e MANSILA, 2018) seguidos pela falta de interesse dos alunos, dos pais de alunos e dos funcionários em participar do projeto (CABRAL e SOUZA, 2013; FONSECA, 2014b; FIOROTTI et al., 2015; PRADO e MANSILA, 2018). Os autores também apontam dificuldades relativas ao terreno utilizado para construção da horta, frequentemente, os terrenos disponíveis são terrenos ociosos na escola que estão desnivelados ou contêm muitos entulhos (FONSECA, 2014a; SILVA et al., 2015; LEAL et al., 2018). Queiroga (2015) também aponta desafios relacionados a disponibilidade e qualidade da água. Neto (2017) relata em seus estudos, desafios intrínsecos ao dia a dia do professor na escola, a começar pela perda de autonomia, o não reconhecimento ao trabalho docente, a defasagem salarial, ou até mesmo, pelo posicionamento de professores que estão alheios às mudanças ou com certo receio a evolução do mundo globalizado, problemas estes que são relatados pela maioria dos professores da rede pública de ensino. A defasagem salarial gera uma desmotivação do trabalho docente e diante da indisciplina dos alunos, os professores sentem-se desmotivados em desenvolver novas práticas de ensino, ou muitas vezes dispõe de um 
conhecimento arcaico e não dominam os avanços tecnológicos disponibilizados na sociedade atual.

As práticas com hortas escolares permitem uma aproximação com a natureza e proporcionam um convívio coletivo e conscientização em relação ao meio ambiente (COSTA, SOUZA e PEREIRA, 2015; FIOROTTI et al., 2015; SILVA et al 2015; SILVA, SOUZA e NASCIMENTO, 2015). Cunha (2015) aponta para a inserção do debate agroecológico e de hortas escolares como políticas públicas da educação, o que poderia fortalecer os campos da saúde, agricultura e educação através de práticas inter/multidisciplinares no processo de ensino-aprendizagem.

Borges, Freitas e Silva (2013) afirmam que através da horta o aluno poderá praticar uma atividade extracurricular, levando-o ao espaço escolar no contra turno e impedindo-o de utilizar esse tempo ocioso para outras atividades não construtivas.

\subsection{EXPERIÊNCIAS RELATADAS POR PROFESSORES QUE FORAM OU PODERÃO SER UTILIZADAS NO ENSINO DE BIOLOGIA ATRAVÉS DE HORTAS ESCOLARES.}

De todos os trabalhos que compuseram o escopo desta revisão, observamos que apenas sete estudos descrevem experiências de professores de Biologia utilizando hortas como ferramentas de ensino. Através das práticas com hortas escolares é possível trabalhar temas pertinentes ao Ensino de Biologia, tais como desenvolvimento sustentável, ciclos biogeoquímicos, relações ecológicas na natureza, impactos ambientais e demais questões ambientais, botânica, alimentação e saúde, convivência com o meio ambiente e uso racional da água, técnicas de produção de mudas e de cultivo, estudo do solo, defensivos agrícolas naturais, agrotóxicos e a saúde humana, importância do processo fotossintético relacionando os fatores luz, oxigênio e gás carbônico, importância da água para o desenvolvimento das plantas, taxonomia e nomenclatura biológica; controle biológico, composição nutricional e medicinal das hortaliças cultivadas na horta; desenvolvimento das plantas (frutos, folhas, caule, raízes, dentro outras), relações dos seres vivos com o ambiente, agricultura orgânica, adubação, , controle biológico , processo de fotossíntese, composição dinâmica do solo, processo de erosão e o manejo do solo (BRITO, 2014; FONSECA, 2014a; RESENDE 
et al, 2014; BACCIOTTI, 2016; ARAÚJO, CABRAL e JUSTI, 2018; SANTOS, 2018; CARVALHO, 2019).

Os professores de Biologia dispõem de uma extensa gama de metodologias que podem ser utilizadas no Ensino de Biologia através de hortas escolares. A partir da análise das experiências de professores de Biologia, através do PROFBIO, fomos instigados a desenvolver atividades que contemplam metodologias ativas, onde o aluno é protagonista do conhecimento, e o professor é um mediador de conteúdo. No presente trabalho, analisamos duas experiências de professores que obtiveram seu título de mestre no PROFBIO e que consideramos metodologias pertinentes ao ensino de Biologia através de hortas escolares, Carvalho (2019) e Silva (2019). O trabalho de Silva corrobora o estudo de Prado e Mansila (2018), pois ambos concordam que a elaboração de um guia prático é pertinente para compreensão do tema Botânica. CruzSilva, Munaretto e Mantovani, (2011), perceberam que uma das principais reclamações dos professores é a falta de materiais que orientem os professores no desenvolvimento de práticas com hortas escolares, nesta perspectiva, os autores apresentaram uma apostila com roteiros de aula prática que foi confeccionada com base em pesquisas e revisão bibliográfica. Eles selecionaram os conteúdos que se enquadravam na possibilidade de serem desenvolvidos como aula prática utilizando a horta da escola.

A maioria dos autores consideram a horta escolar um espaço que potencializa o processo ensino aprendizado de biologia e ainda pode ser utilizado por professores de outras disciplinas tendo um caráter interdisciplinar. Alguns trabalhos relataram a dificuldades de professores em ter material didático para se trabalhar em hortas, sendo assim foi desenvolvido um manual didático na tentativa de amenizar essa defasagem, que é produto dessa dissertação de mestrado (anexo 1). 


\section{CONCLUSÃO}

Em relação aos artigos selecionados para este trabalho foi possível apontar que a maioria dos autores consideram que a utilização de hortas contribui para o processo ensino aprendizagem e desenvolvimento cognitivo e comportamental dos alunos, estimulam o trabalho colaborativo, possibilitam o contato direto dos alunos com a natureza. Além disso, permitem uma conexão entre conhecimento e prática, associação de múltiplos campos de saberes, contribuem para a sensibilização da preservação do meio ambiente e para a formação de cidadãos conscientes e críticos em relação aos problemas ambientais.

Com base nos estudos é possível afirmar que a utilização de hortas escolares é viável como ferramentas de ensino de biologia, pois além de favorecerem a interdisciplinaridade, também permitem o estudo de temas transversais relacionados a Educação Ambiental, bem como, ampliam a atuação do professor para além da sala de aula. Em relação ás limitações ficou evidente que a falta de planejamento, de preparação do professor, de material didático e falta de apoio da comunidade acadêmica em geral, interferem negativamente para o sucesso das hortas escolares. Acreditamos que o manual didático desenvolvido neste trabalho irá contribuir significativamente para preencher a lacuna relacionada a falta de material disponível para os professores. 


\section{REFERÊNCIAS BIBLIOGRÁFICAS}

ABRASCO, Associação Brasileira de Saúde coletiva. Dossiê: um alerta sobre os impactos dos agrotóxicos na saúde. São Paulo: Editora expressão popular, p.29, 2015. Disponível em: https://www.abrasco.org.br/dossieagrotoxicos/wpcontent/uploads/2013/10/DossieAbrasco_2015 web.pdf. Acesso em: 27 Jun. 2021.

AGUIAR, P.C.B. et al. Da teoria a prática em Educação Ambiental. Revista Gestão e Sustentabilidade ambiental, Florianópolis, v. 6, n. 2, p.111-132, jul./set. 2017. Disponível em:

http://www.portaldeperiodicos.unisul.br/index.php/gestao_ambiental/article/view/5154/ 3187. Acesso em 25 nov. 2020.

ALI S. J. et al. Chlorpyrifos Exposure Induces Parkinsonian Symptoms and Associated Bone Loss in Adult Swiss Albino Mice. Neurotox Res. Jul 31, 2019.

ALVES, C. T. A revolução verde e a modernização agrícola na mesorregião noroeste do Rio Grande do Sul - 1930/1970, 2013. Dissertação (mestrado), Universidade de Passo Fundo, Passo Fundo, 2013. Disponível em: http://tede.upf.br:8080/jspui/handle/tede/163. Acesso em 25 nov. 2020.

ANDRADE, D. F. Implementação da Educação Ambiental em escolas: uma reflexão. In: Fundação Universidade Federal do Rio Grande. Revista Eletrônica do Mestrado em Educação Ambiental, v. 4.out/nov/dez. 2000.

ANDRADES, T. O. de; GANIMI, R. N. Revolução verde e a apropriação capitalista. O livro cinza do agronegócio. Ed. Coordenação Nacional da FEAB, Gestão 2009/10 UFPR. Disponível em: https://feab.files.wordpress.com/2008/08/2010-livrocinza121220152015-phpapp02.pdf. Acesso em 25 nov. 2020.

ANSCHAU, J. R. et al. Projeto Horta Viva na escola. Ciência e Natura, Santa Maria v.40, Edição Especial: II mostra de Projetos da UFSM - Campus Cachoeira do Sul, 2018, p. 148-155.

ANVISA, Agência Nacional de Vigilância Sanitária. Divulgado o monitoramento de agrotóxicos em alimentos. Brasília, DF. Publicado em 15 de abril de 2009.

ANVISA. Relatório das Análises de Amostras Monitoradas no Período de 2013 a 2015. Programa de análise de resíduos de agrotóxicos em alimentos. Brasília. 2016.

ARANGO, N.; CHAVES, M. E.; FEINSINGER, P. Principios y Práctica de la Enseñanza de Ecología en el Patio de la Escuela. Instituto de Ecología y Biodiversidad - Fundación Senda Darwin, Santiago, Chile, 2009.

ARAÚJO, C. T. G. M.; CABRAL, M. J. S.; JUST, J. Educação ambiental e a horta escolar como elementos de melhorias para o ensino médio articulado. Revista Caribeña de Ciencias Sociales. 2018. Disponível em: 
https://www.eumed.net/rev/caribe/2018/05/educacao-ambientalbrasil.html//hdl.handle.net/20.500.11763/caribe1805educacao-ambiental-brasi. Acesso em 03 mai. 2021.

AZEVEDO, E.; PELICIONI, M. C. F. Agroecologia e promoção da saúde no Brasil. Rev. Panam Salud Publica. vol.31, n.4, pp. 290-295. 2012.

BACCIOTTI, A. Produção de biodigestor e horta orgânica como elemento integrador entre escola e comunidade. Dissertação (Mestrado), Programa de Pós graduação em Docência para a Educação Básica, Universidade Estadual Paulista "Júlio de Mesquita Filho". 2016.

BANDEIRA, D. P. Práticas sustentáveis na educação: interdisciplinaridade através do projeto horta escolas. Revista de Educação do Cogeime - Ano 22 - n. 43 julho/dezembro 2013 DOI: http://dx.doi.org/10.15599/0104-4834/cogeime. v2 2n43 p53-62

BARBOSA, G. R. Ensino e agroecologia: perspectiva a partir da Escola Olimpya Angélica de Lima. Cadernos de Agroecologia, [S.1.], v. 10, n. 3, 2016. ISSN 22367934. Disponível em: http://revistas.abaagroecologia.org.br/index.php/cad/article/view/19507. Acesso em: 03 mai. 2021.

BARROS, L., DAMBROS, G., MACHADO, D. (2012). Agroecologia na escola: desenvolvimento de atividades agroecológicas na rede pública de ensino de Cachoeira do Sul/RS. Revista Monografias Ambientais, 5(5), 1032-1037.

BERNARDES, T. C.; JESUS, B. C. de; GODOY, H. B. R. de; VIDIGAL, E. C. da S. Projeto horta na escola no período de transição do Colégio João XXIII para CEPI João XXIII. Ciclo Revista (ISSN 2526-8082), [S. 1.], v. 3, n. 1, 2018. Disponível em: https://ifgoiano.edu.br/periodicos/index.php/ciclo/article/view/867. Acesso em: 3 maio. 2021.

BETIM, F.A operação para afrouxar ainda mais a lei de agrotóxicos no Brasil, na contramão do mundo. El Pais, 2018. Disponível em:

https://brasil.elpais.com/brasil/2018/06/26/politica/1530040030_454748.html . Acesso em: 25 jun. 2021.

BORGES, L. 1.; FREITAS, P. H. DE; SILVA, R. A. DE O. Horta escolar: recurso para se discutir a Educação Ambiental. Anais da Semana de Licenciatura, Jataí, GO, p. 1318, jun. 2014. ISSN 2179-6076. Disponível em:

http://revistas.ifg.edu.br/semlic/article/view/441. Acesso em: 03 maio 2021.

BRASIL. Base Nacional Comum Curricular (BNCC). Disponível em: http://basenacionalcomum.mec.gov.br/. Acesso em: 18 jul. 2019 
BRASIL. Lei 7.802/1989. Dispõe sobre a Pesquisa, a Experimentação, a Produção, a Embalagem e Rotulagem, o Transporte, o Armazenamento, a Comercialização, a Propaganda Comercial, a Utilização, a Importação, a Exportação, o Destino Final dos Resíduos e Embalagens, o Registro, a Classificação, o Controle, a Inspeção e a Fiscalização, de Agrotóxicos, seus Componentes, e Afins, e dá outras providências. Diário Oficial da União, Brasília, 12 jul. P. 11459. 1989.

BRASIL. Lei n. 9795 - 27 de abril de 1999. Dispõe sobre a educação ambiental. Política Nacional de Educação Ambiental. Brasília, 1999. Disponível em: https://www.camara.leg.br/proposicoesWeb/prop_mostrarintegra;jsessionid=50EE32BD 99AF52EB7D5DB8E7E03AE765.node1 codteor $=634068 \&$ filename $=$ LegislacaoCitada +-PL+4692/2009. Acesso em 25 nov. 2020.

BRASIL. MEC. Panorama da educação ambiental no ensino fundamental. Brasília: MEC/SEF, 2001.

BRASIL. Parâmetros Curriculares Nacionais . Brasília, DF: MEC/SEF, 1998.

BRITO, J. L. O uso da metodologia de projetos como instrumento de educação ambiental: uma experiência no Colégio Manoel de Jesus. 2014. 53 f. Trabalho de Conclusão de Curso (Especialização) - Universidade Tecnológica Federal do Paraná, Medianeira, 2014.

BRITO, L. F. Educação alimentar e nutricional (ean): produção de horta orgânica como prática pedagógica. $71 \mathrm{f}$. TCC (Graduação) - Curso de Licenciatura em Biologia, Centro de Ciências Agrárias, Ambientais e Biológicas, Universidade Federal do Recôncavo da Bahia, Cruz das Almas, 2019.

BURALLI, J. R. et al. Occupational exposure to pesticides and health symptoms among family farmers in Brazil. Revista de Saúde Pública, v. 54, n. 133, p. 1-12, 2020.

CABRAL, M. M.; SOUSA, M. S. Projeto de horta escolar: estudo de caso no Colégio da Polícia Militar de Rio Verde - GO. Itinerarius Reflectionis, [S. 1.], v. 9, n. 1, 2013. DOI: 10.5216/rir.v1i14.22372. Disponível em:

https://www.revistas.ufg.br/rir/article/view/22372. Acesso em: 3 maio. 2021.

CALDAS, E.D.; SOUZA, L. C. de. Avaliação de risco crônico da ingestão de resíduos de pesticidas na dieta brasileira. Revista de Saúde Pública, v. 34, n. 5, p. 529-537, 2000 .

CANDIOTTO, L. Z. P.; MEIRA, S. G. Agricultura orgânica: uma proposta de diferenciação entre estabelecimentos rurais. CAMPO-TERRITÓRIO: revista de geografia agrária, v. 9, n. 19, p. 149-176, out., 2014.

CAPORAL, F. R.; COSTABEBER, J. A. Agroecologia: alguns conceitos e princípios. Brasília: MDA/SAF/DATER-IICA, 2004. 
CAPRA, F. O ponto de mutação. São Paulo: Editora Cultrix, 1982.

CARNEIRO F. F. et al. Dossiê ABRASCO - Um alerta sobre os impactos dos agrotóxicos na saúde. Associação Brasileira de Saúde Coletiva, Rio de Janeiro, 2015.

CARVALHO, I. C. M. Educação ambiental: a formação do sujeito ecológico. 2.ed. São Paulo: Cortez, 2006.

CARVALHO, M. C de. A horta escolar como ferramenta pedagógica no ensino de biologia. 2019.76 p. Dissertação (mestrado) - Universidade Estadual de Campinas, Instituto de Biologia, Campinas, SP. 2019. Disponível em:

http://repositorio.unicamp.br/jspui/handle/REPOSIP/335462. Acesso em: 03 maio 2021.

CASTRO, J.S.M.; CONFALONIERI, U. Uso de agrotóxicos no município de Cachoeiras de Macacu (RJ). Ciência \& Saúde Coletiva, vol. 10, n. 2, p. 473-82, 2005

CHRISMAN, J. R. et al. Pesticide sales and adult male cancer mortality in Brazil. International Journal of Hygiene and Environmental Health, v. 212, n. 3, p. 310-321, May 2009.

CISCATO, C. H. P. Resíduos de praguicidas em amostras de ovo comercializadas na cidade de São Paulo. 2008. Tese (Doutorado em Patologia Experimental e Comparada) - Universidade de São Paulo, São Paulo, 2008.

COLLERE, M. A. O. Educação ambiental: a contribuição dos projetos escolares nas discussões ambientais nas escolas públicas municipais de Colombo/PR. R. RA'E GA, Curitiba, n. 10, p. 73-82, 2005. Editora UFPR.

COLOSSO, C.; TIRAMANI, M.; MARONI, M. Neurobehavioral effects of pesticides: state of the art. Neuro Toxicology, v. 24, n. 415, p. 577-591, 2003.

COSTA, A. S. V.; FERREIRA, A. C. A. Horta escolar: instrumento para ensinoaprendizagem alimentícia da Escola Estadual Professora Antônia Silva Santos, comunidade do Magazão Velho, Magasão, Amapá. Trabalho de Conclusão de Curso (Graduação em Educação do Campo) - Campus de Mazagão, Universidade Federal do Amapá, Mazagão, 2019.

COSTA, C. A. DA ; SOUZA, J. T. A.; PEREIRA, D. D. Horta escolar: alternativa para promover a educação ambiental e desenvolvimento sustentável no Cariri

Paraibano. POLÊM!CA, [S.l.], v. 15, n. 3, p. 001-009, out. 2015. ISSN 1676-0727.

Disponível em:

https://www.epublicacoes.uerj.br/index.php/polemica/article/view/19350. Acesso em:

03 maio 2021. doi:https://doi.org/10.12957/polemica.2015.19350

CRIBB, S. L. S. P. Contribuições da educação ambiental e horta escolar na promoção de melhorias ao ensino, a saúde e ao ambiente. REMPEC - Ensino, Saúde e

Ambiente, v.3 n 1 p.42-60. Abril, 2010. Disponível em: 
https://periodicos.uff.br/ensinosaudeambiente/article/view/21103/12577. Acesso em: 25 nov. 2020.

CRUZ-SILVA, C. T. A. da; MUNARETTO, F. C.; MANTOVANI, T.Viabilidade da utilização da horta da escola como laboratório para ensino de ciências e biologia. Revista Didática Sistêmica, [S. 1.], v. 13, n. 1, p. 50-63, 2011. Disponível em: https://periodicos.furg.br/redsis/article/view/2002. Acesso em: 3 maio. 2021.

CUBA, M. C. Educação ambiental nas escolas. ECCOM, v. 1, n. 2, p. 23-31, jul./dez., 2010.

CUNHA, A. P. da. Projetos de hortas escolares e debate agroecológico em Pernambuco e no contexto latinoamericano. Giramundo. Revista de Geografia do Colégio Pedro II, v. 2, n. 4. 2015.

DAMS, R. I. Pesticidas: Usos e perigos à saúde e ao meio ambiente. Revista Saúde e Ambiente, v. 7, p. 37-44, 2006.

DIREITO, I. C. N.; FIGUEIRÓ, R.; FLORES, V. R. Impactos dos Pesticidas na Saúde Ambiental e na Saúde Humana. In: FIGUEIRÓ, R. (org.) Saúde \& Ambiente: da Educação Ambiental à Ecologia de Doenças. Volta Redonda: FOA, 2012. p. 39-49.

DOS SANTOS, T. R.; OLIVEIRA, H. S.. Agroecologia como temática de educação ambiental na preservação dos ecossistemas através da redução de agrotóxicos no contexto rural. REMEA - Revista Eletrônica do Mestrado em Educação Ambiental, [S.1.], p. 135-147, nov. 2015. ISSN 1517-1256. Disponível em: https://www.rbhcs.com/remea/article/view/4671/3393. Acesso em: 03 nov. 2020. doi:https://doi.org/10.14295/remea.v0i0.4671.

DUQUE, B. O futuro da Primavera Silenciosa. Revista de Jornalismo Científico e Cultural Universidade Federal de Juiz de Fora, Juiz de Fora, n. A3:09, p. 6-9, jan./ jun. 2016. Disponível em :< https://www.ufjf.br/revistaa3/todas-as-edicoes-2/a309/. Acesso em 25 nov. 2020.

EFFTING, T. R. Educação Ambiental nas Escolas Públicas: realidade e desafios. 2007. 90 f. Monografia (Pós Graduação em "Latu Sensu" Planejamento Para o Desenvolvimento Sustentável) - Centro de Ciências Agrárias, Universidade Estadual do Oeste, Marechal Cândido Rondon, 2007.

FAO, Fao statistical use pesticides years 2000-2018. Food and Agriculture Organization of the United Nations. 2021.

FERNANDES, M. C. A. Orientações para Implantação e Implementação da Horta Escolar. Caderno 2. Brasília, Brasil, 2007.

FERREIRA, L. S. V.. Efeitos histopatológicos dos agrotóxicos deltametrina, imidacloprido, glifosato e diuron nas brânqui. 2016. Dissertação (Mestrado) - Curso de Biologia de Água Doce e Pesca Interior, Instituto Nacional de Pesquisas da 
Amazônia, Manaus, 2016. Disponível em:

https://repositorio.inpa.gov.br/handle/1/11368. Acesso em: 26 nov. 2020.

FIDELES, N. Impactos da Revolução Verde. Radioagencia NP, São Paulo, set. 2006.

FIOROTTI, J.L. et al. Horta: a importãncia no desenvolvimento escolar. XIV

Encontro Latino Americano de Iniciação Científica e X Encontro Latino Americano de Pós-Graduação - Universidade do Vale do Paraíba. p.7. 2015

FONSECA, G. DA. Hortas Agroecológicas: Ecologia e Gestão Ambiental na

Escola. VirtualBooks Editora; Edição 2014. p.60. 2014a.

FONSECA, G. DA. Percepções dos estudantes do curso técnico em administração integrado ao Ensino Médio sobre o uso de práticas em agroecologia urbana no ensino de Biologia e Gestão Ambiental. Góndola, Enseñanza y Aprendizaje de las

Ciencias, ISSN-e 2346-4712, Vol. 9, N. 2, 2014 (Ejemplar dedicado a: JulDec), págs. 79-96. 2014 b.

FREIRE, P. Pedagogia da Autonomia: Saberes necessários a prática educativa. 37 ed. São Paulo: Paz e Terra, 2008.

GAMACHE, P.L. et al. Exposure to pesticides and welding hastens the age-at-onset of Parkinson's disease. Can J Neurol Sci. 2019 Jul 25:1-17

GARCIA, M. A.. Agroecologia e Educação Ambiental. In: ENCONTRO SOBRE EDUCAÇÃO AMBIENTAL NA AGRICULTURA, n.1, 9 e 10 set. 1999, Campinas (SP). Anais... Campinas (SP): Instituto Agronômico de Campinas, 1999.

GLIESSMAN, S. R. Agroecologia: processos ecológicos em agricultura sustentável. 2. ed. Porto Alegre: UFRGS, 2001. p.53-54.

GOMES M.P. et al. Differential effects of glyphosate and aminomethylphosphonic acid (AMPA) on photosynthesis and chlorophyll metabolism in willow plants. Pestic.

Biochem. Physiol. 130, 65-70. 2016.

GONÇALVES, C.W.P. O desafio ambiental. Organizador: Emir Sader. Os porquês da desordem mundial. Mestres explicam a globalização. Ed. Record, Rio de Janeiro, p.107-108, 2004.

GRAZIANO NETO, F. Questão Agrária e Ecologia: Crítica da Agricultura Moderna, São Paulo: Brasiliense, 1985.

GUNATILAKE S. et al. Glyphosate's Synergistic Toxicity in Combination with Other Factors as a Cause of Chronic Kidney Disease of Unknown Origin. Int J Environ Res Public Health. Jul 31;16(15). 2019.

INCA - Instituto Nacional de Câncer José Alencar Gomes da Silva. Posicionamento do Instituto Nacional de Câncer José Alencar Gomes da Silva acerca dos agrotóxicos. 
06 abr. 2015. Disponível em:

https://www.inca.gov.br/sites/ufu.sti.inca.local/files//media/document/posicionamentodo-inca-sobre-os-agrotoxicos-06-abr-15.pdf. Acesso em 30 jun. 2021.

INTERNATIONAL AGENCY FOR RESEARCH ON CANCER (IARC). Malathion. Geneva: WHO, 2015. (IARC Monographs, 112-07).

IRALA, C. H. e FERNANDEZ, P. M. Manual para Escolas. A Escola promovendo hábitos alimentares saudáveis. HORTA. Brasília, 2001. Disponível em: https://bvsms.saude.gov.br/bvs/publicacoes/horta.pdf. Acesso em 25 nov. 2020.

JARDIM, I. C. S. F.; ANDRADE, J. de A.; QUEIROZ, S. C. do N. de. Resíduos de agrotóxicos em alimentos: uma preocupação ambiental global - Um enfoque às maçãs. Quím. Nova, São Paulo, v. 32, n. 4, p. 996-1012, 2009 . Disponível em: http://www.scielo.br/scielo.php?script=sci arttext\&pid=S010040422009000400031\&lng=en\&nrm=iso. Acesso em 03 maio 2021. http://dx.doi.org/10.1590/S0100-40422009000400031.

JOSÉA, L. et al. Analysis of pesticide residues in juice and beverages. Critical Reviews in Analytical Chemistry, v. 34. p. 121-131, 2004.

KRAWCZYK, N. et al. Revisiting cancer 15 years later: exploring mortality among agricultural and non-agricultural workers in the Serrana Region of Rio de Janeiro. American Journal of Industrial Medicine, v. 60, n. 1, p. 77-86, 2017.

KÖCK-SCHULMEYER et al. Occurrence and behavior of pesticides in wastewater treatment plants and their environmental impact. Science of the Total Environment, v. 458-460, p. 466-476, 2013.

KORI R. K. et al. Cholinesterase inhibition and its association with hematological, biochemical and oxidative stress markers in chronic pesticide exposed agriculture workers. J Biochem Mol Toxicol. Jul 23:e22367. 2019.

KRÜGER M. et al. Detection of glyphosate residues in animals and humans. J. Environ. Anal. Toxicol. 4, 2. 2014a

KRÜGER M. et al. Detection of glyphosate in malformed piglets. J. Environ. Anal. Toxicol. 4, 5. 2014b.

LAZZARI, F. M. e SOUZA, A.S. Revolução Verde: impactos sobre os conhecimentos tradicionais. $4^{\circ}$ Congresso Internacional de Direito e Contemporaneidade. Santa Maria: Universidade Federal de Santa Maria, 2017.

LEAL, M. M. et al. A horta como laboratório vivo para trabalhar a interdisciplinaridade no ensino médio. Ciência e Natura, 40, 243-248.v.2019. doi:https://doi.org/10.5902/2179460X35527. 
LEDDA, C. et al. Oxidative stress and DNA damage in agricultural workers after exposure to pesticides. Journal of Occupational Medicine and Toxicology, v. 16, $\mathrm{n}$. 1, p. 2-7, 2021.

LEFF, E. Epistemologia ambiental. 2. ed. São Paulo: Cortez, 2002.

MAGAlHÃES, A. M.; GAZOLA H. Proposta de Educação Alimentar em Creches. In: Congresso Internacional de Educação Infantil 1. 2002, Bombinhas. Anais. Bombinhas: PMPB, 2002.

MARCHÃO, M. S. G.; MACHADO, P. F. L. Alfabetização científica na horta: investigando a nutrição vegetal e o fluxo da energia solar com alunos do ensino médio. Indagatio Didactica, v.10, n.2, 2018.

MARTINEZ, I. C. P.; HLENKA, V. Horta escolar como recurso pedagógico. Revista Eletrônica Científica Inovação e Tecnologia. Medianeira, v. 8, n. 16, 2017.

Disponível em: https://periodicos.utfpr.edu.br/recit/issue/view/329. Acesso em 30 jun. 2021.

MEDEIROS et al. Análise e diagnóstico de projetos de implantação e implementação de hortas caseiras em escolas. Revista Integralização Universitária. Palmas -TO, v.10, n.13. 2015.

MEIRELLES, L.C. Controle de agrotóxicos: estudo de caso do Estado do Rio de Janeiro, 1985/1995. Dissertação de mestrado. Programas de Pós-Graduação de Engenharia da Universidade Federal do Rio de Janeiro, Rio de Janeiro, 1996.

MENDONÇA, S. G.S. Análise da perceoção do impacto ambiental do agrotóxico no meio ambiente e na saúde pelo agricultor na cidade de Paty do Alferes - RJ.

Monografia. Universidade Federal do Rio de Janeiro - Pólo Universitário de três rios 2018. Disponível em:

https://itr.ufrrj.br/determinacaoverde/wpcontent/uploads/2018/07/monografia-samiramendonca.pdf

MINISTÉRIO DA SAÚDE (BR). Portal da saúde. Sisagua . Brasília: Ministério da Saúde; 2018 . Disponível em: http://portalms. saude.gov.br/vigilancia-emsaude/vigilanciaambiental/vigiagua/sisagua

MINISTÉRIO DA SAÚDE. Relatório Nacional de Vigilância em Saúde de Populações Expostas a Agrotóxicos. Brasília. 2016. Disponível em:

http://bvsms.saude.gov.br/bvs/publicacoes/relatorio_nacional_vigilancia_populacoes_ex postas_agrotoxicos.pdf. Acesso em 25 nov. 2020.

MOREIRA, J. C. et al. Avaliação integrada do impacto do uso de agrotóxicos sobre a saúde humana em uma comunidade agrícola de Nova Friburgo, RJ. Ciência e Saúde Coletiva, v. 7, n. 2, p. 299-311, 2002.

MOREIRA, T. Escola sustentável: currículo, gestão e edificação. Espaços Educadores Sustentáveis, v. 21, n. 07, p. 17-22, jun. 2011. Disponível em: 
http://www.nuredam.com.br/files/documentos_mec/194055espacoseducadoressustentav eis.pdf.

MORGADO, F. S. A horta escolar na educação ambiental e alimentar: experiência do Projeto Horta Viva nas escolas municipais de Florianópolis. 2006. Disponível em: http://www.extensio.ufsc.br/20081/A-hortaescolar.pdf

MOTT, L.; SNYDER, K. Pesticide Alert. A Guide to Pesticides in Fruits and Vegetables. San Francisco: Sierra Club Books, 1987.

MUNFORD, D; LIMA, M.E.C.C. Ensinar ciências por investigação: em quê estamos de acordo? Ensaio, Belo Horizonte, v.9, n.1. p.89-111, jan./jun. 2007.

NARCIZO, K. R. S. Uma análise sobre a importância de trabalhar educação ambiental nas escolas. Rev. eletrônica Mestr. Educ. Ambient. ISSN 1517-1256, v. 22, janeiro a julho de 2009.

NETO, J. S. Projeto horta na escola: ação estratégica do PIBID na formação inicial do bolsista de Ciências. Dissertação (mestrado) apresentada ao Programa de Pósgraduação em Ensino de Ciências e Matemática - Instituto Federal de Educação, Ciência e Tecnologia do Ceará/ Campus Fortaleza, Fortaleza, 2017.

OLIVEIRA, E.M. de. Educação Ambiental: uma possível abordagem. 2. ed. Brasília, DF: IBAMA, 2000.

OLIVEIRA, I. B. (Org.). Alternativas emancipatórias em currículo. São Paulo: Cortez Editora, 2004. Série Cultura, Memória e Currículo; vol. 4.

OLIVEIRA, M. S. M. de; BALDINI, C. F. . Horta - cultura popular e ciência identificação científica, propriedades e usos: uma experiência no ensino integral. Revista Cerrados, v. 15, n. 01, p. 214-236, 30 jun. 2017.

OPAS. Organização Pan-Americana da Saúde. Manual de vigilância da saúde de populações expostas a agrotóxicos. Brasília: OPAS/OMS, p.69, 1997.

PALMA, DCA. Agrotóxicos em leite humano de mães residentes em Lucas do Rio Verde - MT. (Dissertação de Mestrado), Cuiabá: UFMT/ISC, 2011.

PAULINO, J.S.; GOMES, R.A. A institucionalização da agroecologia no Brasil: trajetórias acadêmicas e laços discursivos. Revista Sociedade e Estado, v.35, n.1, p. 307-337, 2020.

PEDROZA, E. H. O. O uso indiscriminado de agrotóxicos e a violação dos direitos fundamentais à alimentação saudável, à saúde e ao meio ambiente equilibrado e suas consequências ao cofre da seguridade social. Justiça do Direito, v. 27, n. 1, p. 220-233, 2013. 
PEREIRA, B. F. P.; PEREIRA, M. B. P.; PEREIRA, F. A. A. Horta escolar: enriquecendo o ambiente estudantil. Revista Brasileira de Educação Ambiental, v. 7, n. 1, 2012.

PERES, F.; MOREIRA, J.C., DUBOIS, G. S. É veneno ou é remédio? Agrotóxicos, saúde e ambiente. Rio de Janeiro: Fiocruz, 2003.

PLUTH, T. B.; ZANINI, L. A. G.; BATTISTI, I. D. E. Pesticide exposure and cancer: an integrative literature review. Saúde em Debate, v. 43, n. 122, p. 906-924, 2019.

PRADO, E. W. do; MANSILLA, D. E. P. Demandas de Ensinoaprendizagem apresentadas por professores de Ciências e Biologia da rede estadual no município de Sorriso - MT. Revista Prática Docente, [S. l.], v. 3, n. 1, p. 196-207, 2018. DOI: 10.23926/RPD.2526-2149.2018.v3.n1.p196-207.id178. Disponível em:

http://periodicos.cfs.ifmt.edu.br/periodicos/index.php/rpd/article/view/178. Acesso em: 3 maio. 2021.

QUEIROGA, C. R. S. Implantação de horta agroecológica em escola pública na cidade de São Domingos - PB: Estudo de caso. Dissertação (Mestrado Profissional), Programa de Pós-graduação em Sistemas Agroindustriais, Centro de Ciências e Tecnologia Agroalimentar, Universidade Federal de Campina Grande. 2015.

RAMOS, I. L.; VASCONCELOS, T. H. N. Prática pedagógica a partir da aplicação de atividades contextualizadas sobre o tratamento de água no ensino de química e educação ambiental. Revista de Ensino de Ciências e Matemática, v. 6, n. 3, p. 72-90, 2015.

REBELO, R. M.; CALDAS II, E. D. Avaliação de risco ambiental de ambientes aquáticos afetados pelo uso de agrotóxicos. Química Nova, v.37, p. 1199-1208, 2014

REIGOTA, Marcos. Meio ambiente e representação social. São Paulo: Cortez, 2002.

REZENDE, B. L. A. et al. A interdisciplinaridade por meio da pedagogia de projetos: uma análise do projeto "Horta Escolar: aprenda cultivando hortaliças" numa perspectiva CTSA. Revista Eletrônica Debates em Educação Científica e Tecnológica - ISSN: 2236-2150, [S.1.], v. 4, n. 01, mar. 2015. ISSN 2236-2150. Disponível em: https://ojs2.ifes.edu.br/index.php/dect/article/view/138. Acesso em: 03 maio 2021.

RIBAS, P. P.; MATSUMURA, A. T. S. A química dos agrotóxicos: impactos sobre a saúde e meio ambiente. Revista Liberato, v. 10, n. 14, p. 149-158, jul./dez., 2009.

RIBEIRO, D. C. A.; PASSOS, C. G.; SALGADO, T. D. M. Horta escolar: uma alternativa interdisciplinar para a Educação ambiental e produção de alimentos sem agrotóxicos. ANAIS do 5 Simpósio sobre Sistemas Sustentáveis, v. 1, p.1537. 2019.

RIBEIRO, M. L. et al. Contaminação de águas subterrâneas por pesticidas: avaliação preliminar. Química Nova, v. 30, n. 3, Jun., 2007. 
ROSA, A. V. Agricultura e Meio Ambiente. $7^{\text {a }}$ edição. São Paulo: Atual, 1998.

SANTANA, V. S.; MOURA, M. C. P.; NOGUEIRA, F. F. Mortalidade por intoxicação ocupacional relacionada a agrotóxicos, 2000-2009, Brasil. Revista de Saúde Pública, São Paulo, v. 47, n. 3, p. 598-606, 2013.

SANTOS, C.O. Horta na escola: proposta pedagógica numa escola do Cariri Paraibano. Trabalho de Conclusão de Curso (Artigo), Curso de Especialização em Ciências da Natureza e Matemática para a Convivência com o Semiárido, Centro de Desenvolvimento Sustentável do Semiárido, Universidade Federal de Campina Grande, Sumé - Paraíba - Brasil, 2018.

SANTOS, E.T.A. Educação ambiental na escola: conscientização da necessidade de proteção da camada de ozônio. Monografia, Universidade Federal de Santa Maria, Santa Maria, 2007.

SANTOS, S. L. Avaliação de parâmetros da imunidade celular em trabalhadores rurais expostos ocupacionalmente a agrotóxicos em Minas Gerais. 2003. $107 \mathrm{f}$. Dissertação (Mestrado em Bioquímica e Imunologia)-Departamento de Bioquímica e Imunologia, Instituto de Ciências Biológicas, Universidade Federal de Minas Gerais, Belo Horizonte, 2003.

SASSERON, L. H.; CARVAHO, A. P. Construindo argumentação na sala de aula: a presença do ciclo argumentativo, os indicadores de alfabetização científica e o padrão de Toulmin. Ciência e Educação Bauru, v. 17, n. 1, p. 97-114, 2011

SEVILLA GUSMÁN, E. A perspectiva sociológica em Agroecologia: uma sistematização de seus métodos e técnicas. Trad. Francisco Roberto Caporal. In: Revista Agroecologia e Desenvolvimento Rural Sustentável. v. 3, n.1. Porto Alegre: EMATER, jul./set. 2002.

SILVA, A. C. D. ; SOUZA, A. A. e NASCIMENTO, C. R. Horta na escola: sustentabilidade e hábitos saudáveis no município de Cantá-RR. Revista Atas de Saúde Ambiental, v. 2, n.3, p. 80-89. 2015.

SILVA, E. C. R. et al. Hortas escolares: possibilidades de anunciar e denunciar invisibilidades nas práticas educativas sobre alimentação e saúde. Alexandria: Revista de Educação em Ciência e Tecnologia, 8(1), 265-288. 2015.

SILVA, H. M. DA. Implantação da horta escolar na escola Santo Afonso. 35 f. TCC (Licenciatura em Química) - Universidade Federal do Ceará, Fortaleza, 2015.

SILVA, J. M. da, et al. . Agrotóxico e trabalho: uma combinação perigosa para a saúde do trabalhador rural. Ciênc. saúde coletiva, Rio de Janeiro , v. 10, n. 4, p. 891-903, Dec. 2005 .Disponível em:

http://www.scielo.br/scielo.php?script=sci_arttext\&pid=S1413-

$81232005000400013 \& \operatorname{lng}=$ en\&nrm=iso. Acesso em: 29 out. 2020. 
SILVA, J. P. de O.; FREIRE, J. L. de O. Horta escolar de base agroecológica: reflexos no processo ensino-aprendizagem e nos hábitos alimentares de alunos da zona rural de Picuí, PB IFPB, campus Picuí, 2012.

SILVA, T. M. S. Iniciação Científica com Projetos de Botânica no Ensino Médio. Dissertação (Mestrado Profissional em Ensino de Biologia em Rede Nacional) Instituto de Ciências Biológicas e da Saúde, Programa de Pós Graduação em Ciências Biológicas e da Saúde, Universidade Federal de Alagoas, 2019.

SOARES, W. L.; FREITAS, E. A. V.; COUTINHO, J. A. G. Trabalho rural e saúde: intoxicações por agrotóxicos no município de Teresópolis - RJ. Revista de Economia e Sociologia Rural, Rio de Janeiro, v. 43, n. 4, p. 685-701. 2005.

SOLINO, A.P.; GEHLEN, S. T. Abordagem temática freireana e o ensino de ciências por investigação: possíveis relações epistemológicas e pedagógicas. Investigações em ensino de Ciências. v.19, n.1, p.141-162, 2014.

TAVARES, D. C. G. et al. Utilização de agrotóxicos no Brasil e sua correlação com intoxicações . Sistemas e Gestão, v. 15, n. 1, p. 2-10, 13 abr. 2020.

TERRA, S. B.; MATTIA, J. L. DE; JASKULSK, G. F. Produção de hortaliças orgânicas na escola: promoção de hábitos saudáveis e o cuidado com meio ambiente. Revista Em Extensão, v. 14, n. 1, p. 52-75, 12 ago. 2015.

TOZONI-REIS, M. F. C.; CAMPOS, L.M. L. Educação ambiental escolar, formação humana e formação de professores: articulações necessárias. Educar em Revista, Curitiba, Brasil, Edição Especial n. 3/2014, p. 145-162. Editora UFPR.

TRAJBER, R. Vida sustentável: ações individuais e coletivas. Espaços Educadores Sustentáveis, v. 21, n. 07, p. 22-29, jun. 2011. Disponível em:

http://www.nuredam.com.br/files/documentos_154 Colloquium Humanarum, Presidente Prudente, v. 16, n. 2, p.146-154 abr/jun 2019. DOI:

10.5747/ch.2019.v16.n2.h424 mec/194055espacoseducadoressustentaveis.pdf.

VIEIRA, E. M. et al. O. Estudo da adsorção/ dessorção do ácido 2,4

diclorofenoxiacético $(2,4-\mathrm{D})$ em solo na ausência e presença de matéria orgânica.

Química Nova, v. 22, p. 305-308, 1999.

WORLD HEALTH ORGANIZATION. Exposure to Highly Hazardous Pesticides: a Major Public Health Concern. Geneva, 2010.

ZAGANAS, I. et al. Linking pesticide exposure and dementia: what is the evidence? Toxicology. 2013 May 10;307:3-11. doi: 10.1016/j.tox.2013.02.002. Epub 2013 Feb 14. PMID: 23416173. 


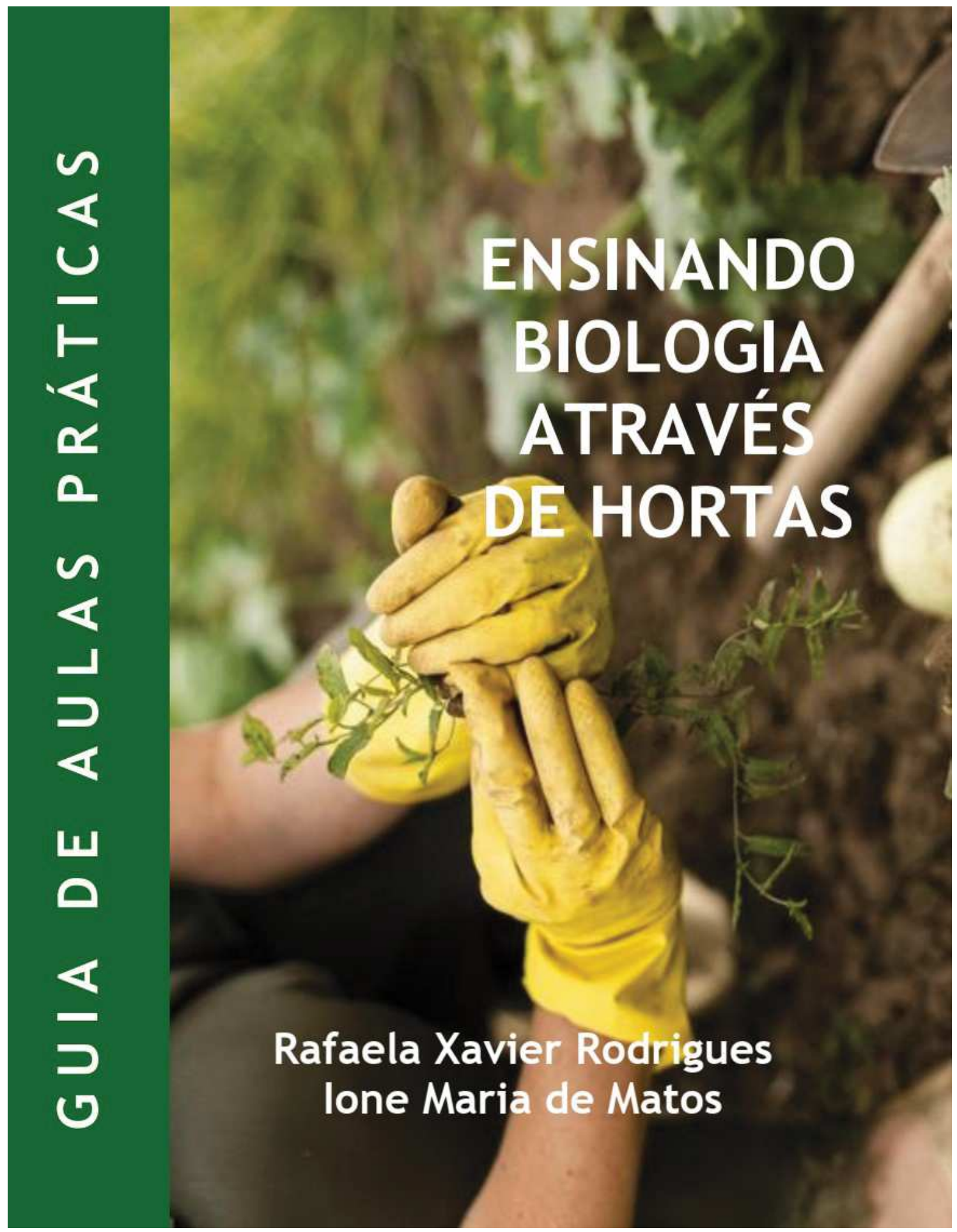




\section{ENSINANDO BIOLOGIA ATRAVÉS DE HORTAS}

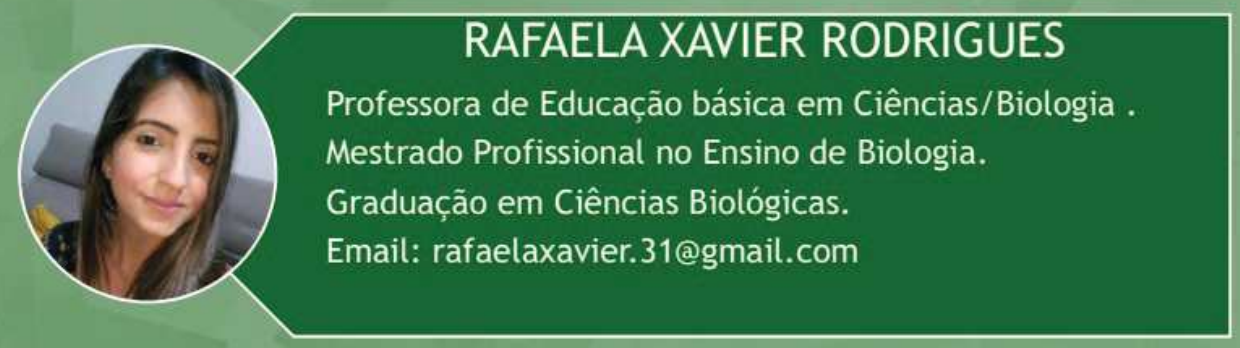

\section{IONE MARIA DE MATOS}

Professora adjunta da Universidade Federal de Juiz de Fora Campus Governador Valadares.

Doutorado em Ciências Biológicas: Fisiologia e Farmacologia.

Mestrado em Ciências Biológicas: Fisiologia e Farmacologia.

Graduação em Ciências Biológicas.

Email: ione.matos@ufjf.edu.br 


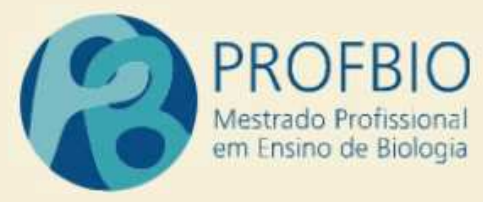

Este guia de aulas práticas é o produto da dissertação de mestrado apresentada ao Mestrado Profissional em Ensino de Biologia (PROFBIO) pela mestranda Rafaela Xavier Rodrigues sob a orientação da Professora Doutora Ione Maria de Matos.

Apoio:

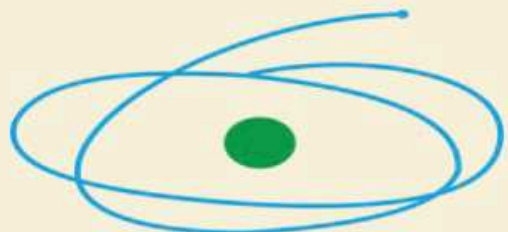

C A P E S

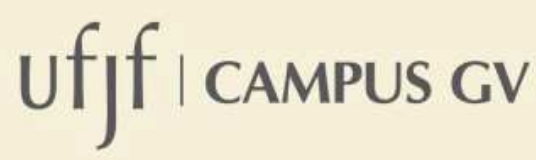

$\mathrm{UF} m \mathrm{G}$

UNIVERSIDADE FEDERAL DE MINAS GERAIS 
SUMÁRIO

APRESENTAÇÃO $\quad 4$

INTRODUÇÃo $\quad 6$

CONTEXTUALIZANDO BIOLOGIA E HORTAS ESCOLARES 8

COMO FAZER UMA HORTA 10

PASSO A PASSO DE COMO MONTAR UMA HORTA

PRÁTICAS COM HORTAS ESCOLARES $\quad 15$

AGROTÓXICOS "SIM" OU "NĀO" ? 16

$\begin{array}{ll}\text { AGRICULTURA ORGÂNICA } & 21\end{array}$

INVESTIGANDO O PROCESSO DE COMPOSTAGEM 25

TAXONOMIA VEGETAL $\quad 30$

NUTRIÇÃO HUMANA

FOTOSSÍNTESE E RESPIRAÇÃO 35

$\begin{array}{ll}\text { CLONAGEM VEGETAL } & 38\end{array}$

ADUBAÇÃO DO SOLO 42

REFERÊNCIAS BIBLIOGRÁFICAS 


\section{APRESENTAÇÃO}

Caros educadores,

Este guia de aulas práticas com hortas escolares, sugere ao professor de Biologia algumas possibilidades do uso de hortas escolares para o ensino da disciplina.

Atualmente, o debate ambiental têm sido um tema presente nas mídias digitais, em congressos, seminários, entre outros, e vejo que alguns professores sentem dificuldade em inserir estes temas no seu planejamento de ensino, seja por falta de formação adequada, por falta de tempo, recursos financeiros ou material didático que possa orientá-lo no desenvolvimento de suas aulas.

Portanto, a proposta deste trabalho surgiu da nossa preocupação com o meio ambiente; com a segurança alimentar da sociedade e da necessidade de trabalhar estes temas dentro do ambiente escolar.

Para elaboração deste guia, foi realizada a leitura de publicações científicas que relatavam experiências utilizando hortas escolares como ferramenta de ensino, e as pesquisas permitiram concluir que uma das dificuldades apontadas pelos professores foi a falta de um material didático com práticas envolvendo hortas escolares.

Neste contexto, julgamos conveniente e necessário o desenvolvimento de um guia de aulas práticas no formato digital para orientar o professor de Biologia sobre a utilização de hortas escolares como ferramentas de ensino. 
Muitas escolas já desenvolvem projetos que contemplam atividades com hortas escolares, mas nem sempre têm cunho pedagógico e interdisciplinar. O uso de novas metodologias de ensino que abordem de forma transversal temas pertinentes à Educação Ambiental, contribuem para a formação de cidadãos críticos sobre temas relacionados a sociedade e ao ambiente.

A disciplina de Biologia está intimamente ligada a questões relacionadas ao ambiente e por esse motivo, vejo que os professores desta área são os mais indicados para trabalhar este tema e quando existe trabalho coletivo nas escolas, que envolve não somente funcionários mas também a comunidade ao redor, alcançamos maior êxito em nossas práticas.

Por esse motivo, selecionamos algumas metodologias de ensino ligadas a práticas com hortas escolares que possibilitam a compreensão do conteúdo de Biologia.

Espero, que você, professor de Biologia possa utilizar estas práticas para dinamizar suas aulas. 


\section{CONTEXTUALIZANDO BIOLOGIA E}

HORTAS ESCOLARES

Segundo a BNCC (Base Nacional Curricular Comum) a área de Ciências da Natureza deve contribuir para a construção de uma base de conhecimentos contextualizada, e preparar os jovens para enfrentar os desafios contemporâneos de forma crítica responsável e ética, o mundo deve lhes ser apresentado como campo aberto para investigação e intervenção quanto a seus aspectos sociais, produtivos, ambientais e culturais. (BRASIL, 2018)

Neste contexto, a horta inserida no ambiente escolar pode ser um laboratório vivo que possibilita o desenvolvimento de diversas atividades pedagógicas em educação ambiental e capaz de unir teoria e prática de forma contextualizada (MORGADO, 2006).

Barbosa, 2009, entende que a horta na escola é uma estratégia viva, capaz de:

- Promover estudos, pesquisas, debates e atividades sobre as questões ambiental, alimentar e nutricional;

- Estimular o trabalho pedagógico dinâmico, participativo, prazeroso, inter e transdisciplinar;

- Proporcionar descobertas;

- Gerar aprendizagens múltiplas;

- Integrar os diversos profissionais da escola por meio de temas relacionados com a educação ambiental, alimentar e nutricional. 


\section{COMO FAZER UMA HORTA?}

Caro professor, para fazer uma horta na sua escola, você precisará de planejamento.

Coloque a mão na massa e faça um pequeno projeto da sua horta, desta forma, você poderá aproveitar melhor o tempo e ainda poderá contar com a ajuda dos demais funcionários da escola e até mesmo com a ajuda da comunidade.

Como hortas também exigem técnica para serem cultivadas, o Serviço Nacional de Aprendizagem Rural (SENAR) oferece o curso de olericultura (horta orgânica), totalmente gratuito; este curso pode ser realizado por maiores de dezoito (18) anos e através dele, os participantes aprenderão como fazer uma horta orgânica.

Caso, não consiga realizar o curso, não se preocupe! Existem diversas cartilhas de instrução sobre como montar uma horta, como sugestão você poderá utilizar o manual disponibilizado pela EMBRAPA denominado "Como Implantar e Conduzir uma Horta de Pequeno Porte" (EMBRAPA, 2012), assim como o manual "Horta em pequenos espaços" (EMBRAPA, 2012).
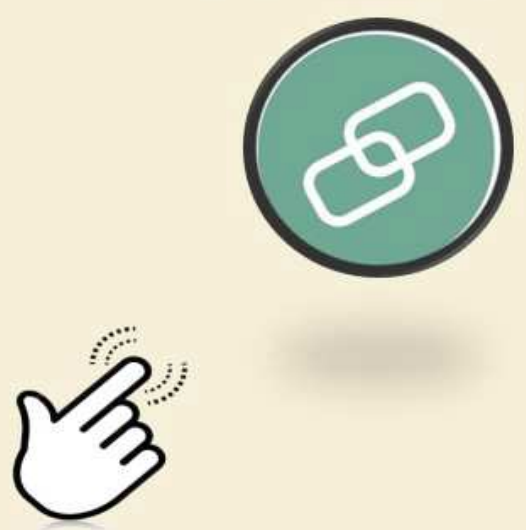


\section{$2^{\circ}$ passo: escolha de ferramentas.}

Para o preparo dos canteiros, será necessário providenciar algumas ferramentas, como:

- Enxada: que será utilizada para

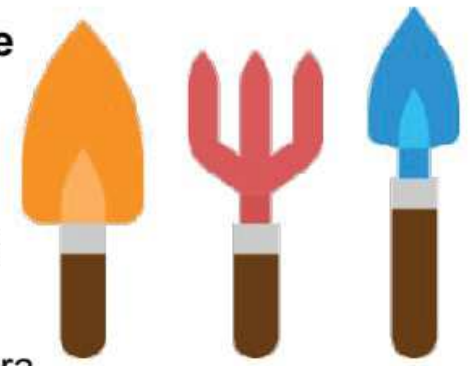
capinar, abrir sulcus e misturar adubos e corretivos como serragem a terra;

- Enxadão: utilizado para cavar e revolver a terra;

- Pá: para depositar ou retirar terra e adubo;

- Regador ou mangueira: serão utilizados para irrigar a horta;

- Carrinho-de-mão: para transportar terra, adubo e ferramentas;

- Luvas para os alunos.

\section{$3^{\circ}$ passo: preparo do solo e} canteiros.

O solo que será utilizado na preparação dos canteiros deverá ser preparado corretamente. Sugere-se que seja feita uma colet a do solo para análise a fim de verificar os nutrientes disponiveis

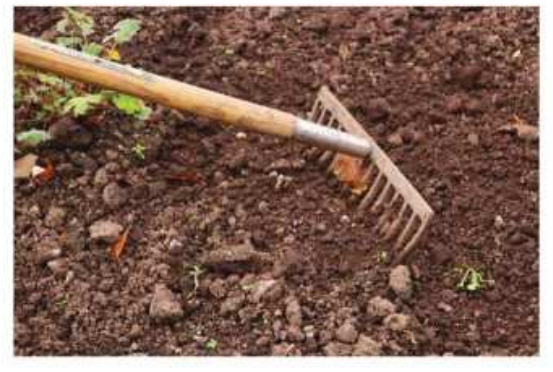
no solo e providenciar a adubação mineral caso necessário . As pedras, pedaços de madeira, entulhos e outros objetos que possam estar dispersos no local deverão ser retirados. O solo deverá ser revolvido para não ter torrões e a terra ficar bem fofa. 
Quando as plantinhas estiverem com 4 ou 5 folhas, serão trasnplantadas para os canteiros.

O transplante deve ser feito com o auxílio de uma pequena pá ou colher para não romper as raízes. É recomendável regar as sementeiras antes de realizar o transplante das mudas e deverá ocorrer preferencialmente pela manhã ou no final da tarde.

\section{Quando plantar!}

Deve-se respeitar a época de plantio das espécies cultivadas que, em geral, está entre os meses de fevereiro e setembro (ver Tabela 1). Este período pode ser estendido com o uso de sombrite preto $50 \%$ ou $75 \%$, para limitar a penetração de luz e, consequentemente, criar um microclima mais adequado.

\section{Como cuidar da horta!}

Para a horta ter sucesso deve-se ter um bom cuidado com as hortaliças que serõa plantadas no local.

- Uma horta deve ser irrigada, pelo menos, duas vezes ao dia, de acordo com a espécie cultivada. Para facilitar a irrigação poderá ser utilizado o sistema de gotejamento ou aspersores;

- Deve-se manter sempre livre de plantas invasoras, realizando a catação semanal das mesmas;

- Para o combate de pragas deverão ser utilizados técnicas de controle biológico e preparação de insumos naturais eficazes no controle de pragas;

- A cada colheita deve ser feita a reposição de adubo e terra para o recebimento de uma nova hortaliça, e recomenda-se a rotação de culturas. 


\section{AGROTÓXICOS "SIM ou NÃO"?}

\section{Objetivos:}

Sensibilizar os alunos sobre o uso de agrotóxicos no Brasil e sobre a importância de uma alimentação saudável, livre de resíduos químicos.

\section{Habilidades da BNCC:}

(EM13CNT104) Avaliar potenciais prejuízos de diferentes materiais e produtos à saúde e ao ambiente, considerando sua composição, toxicidade e reatividade, como também o nível de exposição a eles, posicionando-se criticamente e propondo soluções individuais e/ou coletivas para o uso adequado desses materiais e produtos. (EM13CNT206) Justificar a importância da preservação e conservação da biodiversidade, considerando parâmetros qualitativos e quantitativos, e avaliar os efeitos da ação humana e das políticas ambientais para a garantia da sustentabilidade do planeta.

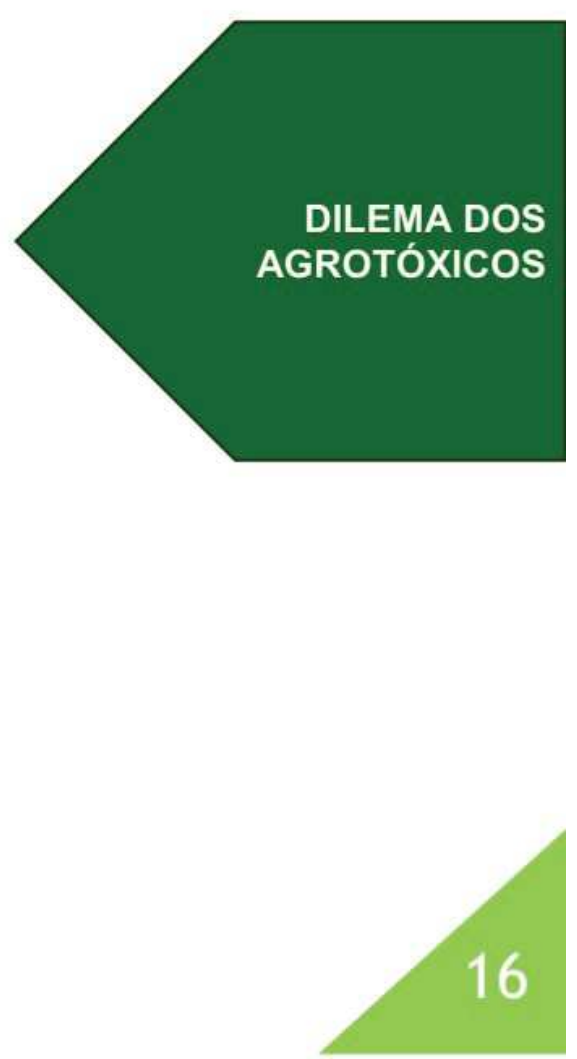




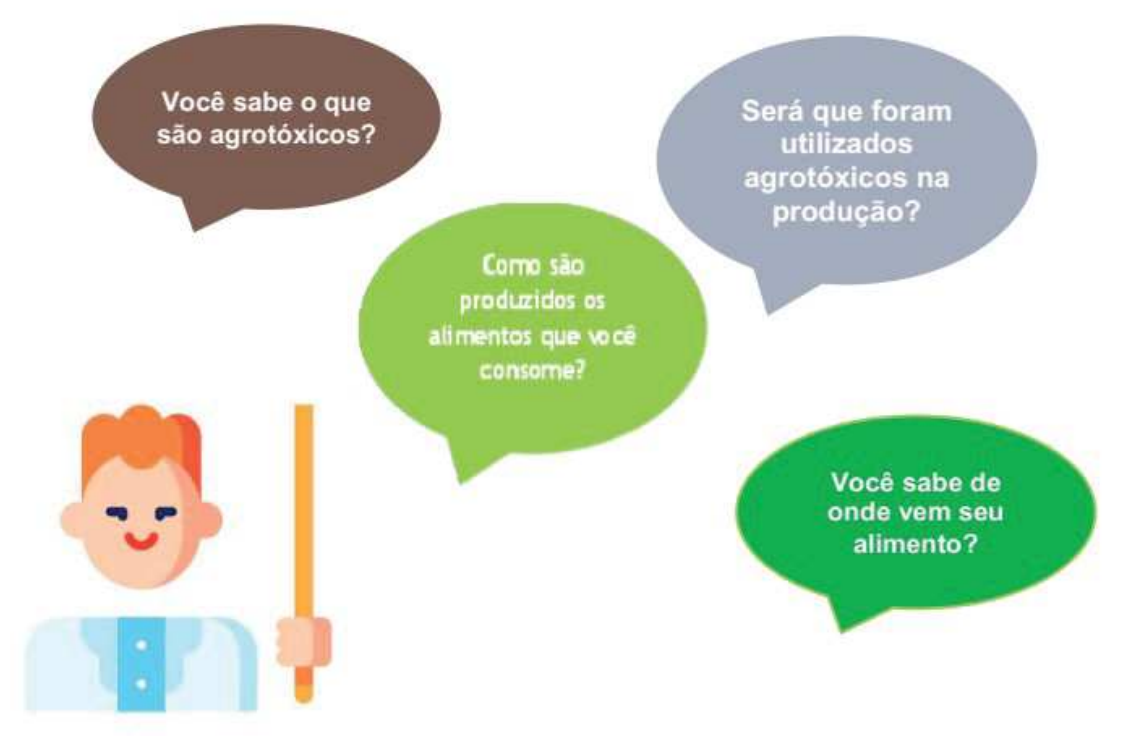

Após introduzir um breve debate com os seus alunos sobre a origem dos alimentos, sugerimos que o professor utilize metodologia de Estudo de caso, que constitui uma metodologia ativa de ensino na qual os alunos participam ativamente na resolução de questões relativas ao caso.

\section{Estudo de caso "Tomateiro doente"}

O Senhor João cultiva uma plantação de tomates em sua propriedade rural e comercializa na feira da cidade. No entanto, a última colheita do $\mathrm{Sr}$. João não teve muito sucesso pois sua plantação está sofrendo com uma praga que têm causado a desfolha dos tomateiros e provocando uma consequente redução da área fotossintética das plantas e exposição dos frutos ao sol, diminuindo a coloração dos mesmos. O Sr. João está desesperado com a situação, pois a plantação de tomates é uma das suas principais fontes de renda. Sr. João está pensando em 
O professor poderá estipular um prazo para que os alunos realizem as pesquisas de forma que possam preparar os argumentos para defenderem sua ideia. Sugerimos que os alunos disponham do prazo de uma semana para realizarem suas pesquisas. Professor e alunos poderão encontrar informações utilizando as seguintes fontes de consulta virtual:

https://www.grupocultivar.com.br/artigos/efeito-letal. Acesso em 12 dez. 2020.

https://www.bibliotecaagptea.org.br/agricultura/defesa/livros/DOE NCAS\%20DO\%20TOMATEIRO.pdf. Acesso em 12 dez. 2020.

https://blogagro.basf.com.br/septoriose-no-tomateiro-conheca-esaiba-como-manejar-a-doenca-746/n. Acesso em 12 dez. 2020.

https://brasilescola.uol.com.br/geografia/agrotoxicos.htm. Acesso em 12 dez. 2020.

https://g1.globo.com/economia/agronegocios/noticia/2019/10/07/p or-que-a-producao-rural-depende-tanto-de-agrotoxicos.ghtml. Acesso em 12 dez. 2020. 


\section{Problematização:}

A agricultura orgânica consiste em uma prática agrícola que foca na qualidade dos alimentos, todo o processo de produção agrícola deve ocorrer de forma natural e sustentável. Neste tipo de cultivo não são utilizados agrotóxicos ou fertilizantes químicos em nenhuma das fases de produção. O cultivo orgânico apresenta-se como uma alternativa ao uso de agrotóxicos e além de não causar impactos no ambiente, garantem ao ser humano uma alimentação saudável e com qualidade. Com o desenvolvimento desta aula, esperamos que os alunos possam investigar as técnicas de cultivo orgânico e reproduzir os conhecimentos adquiridos no cultivo da horta escolar, além de estimular o trabalho em grupo.

\section{Metodologia:}

Sugerimos que o professor apresente aos alunos o vídeo "João das Alfaces", filme produzido pela Embrapa, adaptado do livro "A história de Seu João das Alfaces - Uma introdução à agricultura orgânica ". Disponivel em https://www.youtube.com/watch?v=WilUUhn3nEc\&t=770s.

Acesso 13 dez. 2020.

Após exibição do filme, o professor poderá estimular o debate entre os alunos com perguntas como:

- É necessário utilizar agrotóxicos no cultivo agrícola?

- Podemos controlar as pragas da horta somente com agrotóxicos?

- Vocês sabem o que é agricultura orgânica? 
Cada grupo de alunos ficará responsável por pesquisar um dos temas. As pesquisas realizadas deverão conter informações sobre como utilizar a técnica no cultivo orgânico e quais os benefícios.

Os alunos irão apresentar as técnicas em um seminário com todos os participantes do projeto de horta escolar.

Sugerimos que o professor faça a intermediação do seminário e após a apresentação o professor poderá propor aos grupos de alunos que façam uma história em quadrinhos com o tema da pesquisa, os alunos que tiverem habilidades em desenhar, poderão fazer os desenhos à mão. Caso os alunos não tenham habilidade em desenhar, poderão utilizar o aplicativo PIXTON, disponivel em: https://www.pixton.com (acesso em 13 dez. 2020) para montagem dos quadrinhos. Através do aplicativo os alunos podem encaminhar os quadrinhos para o professor a fim de que o professor possa avalia-los e fazer as possíveis correções. Sugerimos que os quadrinhos sejam impressos e seja montado um mini livreto com as histórias em quadrinhos elaboradas pelos alunos.

Dicas de materiais para realização de pesquisas pelos alunos.

https://www.scielo.br/scielo.php?script=sci_arttext\&pid=S0034737X2014000700008. Acesso em 12 dez. 2020.

https://www.embrapa.br/busca-de-solucoes-tecnologicas//produto-servico/94/cultivo-organico-de-hortalicas. Acesso em 12 dez. 2020. 


\section{Problematização:}

A compostagem consiste no aproveitamento de matéria orgânica em adubo orgânico. Através do processo de compostagem os alunos podem assimilar conceitos relacionados a decomposição e ciclagem dos nutrientes assim como estimular a redução do uso de fertilizantes químicos, por ajudar na manutenção da microbiota do solo e suas características intrínsecas, e por dar um destino adequado ao resíduo orgânico, favorecendo a sustentabilidade (SILVA e INTORNE, 2018). O uso de práticas experimentais com composteiras permite que os alunos possam observar e compreender o processo de compostagem em todas as suas etapas e através da aplicação de questionários pelo professor o mesmo será instigado a formular explicações sobre o processo. A experimentação é relevante para a educação em Ciências, porque através dela o aluno explora sua criatividade, seu senso crítico, se bem explorado pelo professor, melhora seu processo de ensino-aprendizagem e sua alto-estima (GONÇALVES e GOI, 2017).

\section{Metodologia:}

Sugerimos que o professor inicie a aula problematizando o conteúdo através das seguintes abordagens:

- Para aonde vai o lixo da sua casa?

- Os restos de comida são descartados junto com o lixo?

- Vocês já ouviram falar em Compostagem? 
d) Como restos animais pode-se usar miúdos de aves, restos de peixes ou esterco, ou ainda terra de jardim;

e) Deve-se colocar uma camada de terra com cerca de $2 \mathrm{~cm}$ de espessura a cada três dias;

f) Após o enchimento do caixote ou o buraco, deve-se observar se a fermentação está ocorrendo. Isto pode se perceber pelo calor que é produzido no composto. Esse processo é natural e indica um bom funcionamento do sistema;

g) Caso o composto esteja muito seco, os microrganismos não conseguirão decompô-lo, então se recomenda regar, mas sem encharcar e escorrer água (chorume).

\section{Condições do composto:}

Uma maneira simples de saber se é necessário colocar água, é introduzir uma vara de madeira na pilha e deixar permanentemente. Verifique periodicamente se está:

a) Fria e molhada: não está havendo fermentação, provavelmente por excesso de água. Revire o composto e não molhe;

b) Levemente morna e seca, com filamentos brancos: a pilha necessita de um pouco mais de água;

c) Quente, úmida e manchada de pardo-escuro: as condições estão corretas; livre de "barro preto", com cheiro de mofo, podendo ser introduzida com facilidade na pilha de volta: o composto está pronto. Este ponto será alcançado de 60 a 90 dias após o início da fermentação. Para aproveitar este período, podem-se revezar duas caixas ou buracos, enquanto em um estará fermentando, na outra se formará uma nova pilha. 
Os alunos deverão fazer um relatório mensal com as observações feitas durante o processo de compostagem, também poderão fotografar o processo mensalmente. Nas observações, escreva sobre a decomposição de matéria orgânica (se foi parcial ou total). Aspecto da composta (cor) se ouve ou não liberação de gases, odor exalado dentre outros que julgarem adequados.

No final do terceiro mês, esperamos que o composto esteja pronto para ser utilizado na horta da escola. A partir das observações feitas pelos os alunos, os mesmos deverão responder as seguintes perguntas:

a) Qual o material orgânico demorou mais tempo para se decompor?

b) O que provocou a decomposição desses materiais?

c) Qual material se decompôs mais rapidamente?

d) Foi observada alguma mudança da matéria orgânica durante o processo de compostagem? Qual?

e) Quais os fatores químicos, físicos e biológicos que ocorrem na compostagem? $\mathrm{E}$ as variáveis que interferem no processo?

f) Quais são as vantagens em se usar um composto desse tipo?

g) Proponha outras duas medidas que reduzam o acúmulo de lixo nas cidades. O que seria preciso fazer para colocá-los em prática?

Esta atividade foi adaptada do Caderno de Práticas experimentais investigativas em Ensino de Ciências. Disponível em: https://educimat.ifes.edu.br/images/stories/Publica\%C3\%A7\%C3 \%B5es/Livros/lfes_Livro-Praticas-Experimentais-_2012.pdf.

Acesso em 12 dez. 2020.

Caro professor, caso julgue necessário, poderá fazer adaptações! 


\section{Problematização:}

Os conteúdos de Biologia relacionados a nomenclatura e classificação biológica geralmente despertam pouco interesse nos alunos. Esperamos que com o desenvolvimento desta atividade na horta escolar associado ao uso de tecnologias como o aplicativo Plantnet, desperte o maior interesse do aluno e que desta forma o mesmo possa compreender a importância da taxonomia no ramo da Biologia.

\section{Metodologia:}

Sugerimos a utilização da horta escolar para que os alunos possam assimilar conceitos desenvolvidos nas aulas teóricas sobre taxonomia vegetal.

O professor poderá dividir a turma em pequenos grupos e cada grupo será responsável por fazer a identificação biológica dos espécimes vegetais encontrados na horta, caso seja possível, os alunos deverão baixar o aplicativo Plantnet em seus aparelhos telefônicos, o aplicativo encontra-se disponivel no link: https://play.google.com/store/apps/developer?id=plantnet-

project.org, o aplicativo faz a identificação das plantas através de fotos. Caso a escola disponha de uma sala de informática, as pesquisas poderão ser realizadas na mesma.

Após realizarem a identificação biológica das plantas os alunos irão montar plaquinhas com os resultados das pesquisas. Para montagem das plaquinhas, sugere-se a impressão do material encontrado. Também deverão providenciar palitos de picolé e/ou churrasco para fixar as plaquinhas na horta, papel contact e/ou fita adesiva transparente para proteger o material 
impresso. Desta forma, ao visitar a horta, os demais alunos da escola também poderão identificar as espécies cultivadas na mesma.

Através desta atividade o professor poderá trabalhar com os alunos as categorias taxonômicas e as regras de nomenclatura biológica. 


\section{Problematização:}

Um dos principais objetivos do uso de hortas escolares como ferramenta de ensino é despertar nos alunos hábitos de alimentação saudável, uma vez que as hortaliças e leguminosas cultivadas constituem importante fonte de nutrientes e fibras alimentares. Neste contexto, esperamos que a atividade proposta possa contribuir.

\section{Metodologia:}

Os alunos deverão formar grupos de 2 ou três alunos e cada grupo ficará responsável por pesquisar sobre um tipo de hortaliça ou leguminosa cultivada na horta. Os alunos deverão pesquisar sobre os benefícios das plantas para a saúde humana e as informações nutricionais das mesmas, poderão utilizar como fonte de pesquisa o site https://www.tabelanutricional.com.br/.

Os alunos poderão utilizar gráficos para representar as informações nutricionais das plantas. Sugerimos que os resultados das pesquisas sejam apresentados em formato padrão e que seja montado um manual nutricional da horta com todas as informações coletadas pelos alunos.

Sugerimos que os alunos formem uma roda de conversa ao exporem os resultados para a turma e o professor. O professor poderá intermediar a aula fazendo referências sobre os nutrientes presentes nas plantas e sobre sua importância para a saúde humana.

Desta forma, esperamos que o aluno compreenda a importância de uma alimentação saudável e identifique os nutrientes presentes nas plantas que contribuem para a nutrição humana. 


\section{Problematização:}

O tema fotossíntese é trabalhado na sala de aula desde os anos iniciais da educação básica, no entanto, os alunos o associam apenas ao conceito de transformação de energia luminosa em energia química, ou como o processo através do qual as plantas produzem oxigênio. Neste contexto, notamos a necessidade de introduzir o tema de uma forma mais significativa, através do desenvolvimento de práticas experimentais onde os alunos poderão observar e elaborar hipóteses sobre o processo de fotossíntese, os agentes envolvidos e interferência de fatores externos.

\section{Metodologia}

Os alunos deverão formar grupos e cada grupo de cinco alunos, precisará de quinze vasos ou garrafa pets contendo terra preta, e em cada vaso colocarão cerca de 10 sementes de cebolinha, com etiqueta identificar a data e numerar os vasos. Para cada situação abaixo, plantar cinco vasos. Os alunos deverão prosseguir da seguinte forma:

$1^{\circ}$ Vaso: colocar em lugar que tenha luminosidade e molhar diariamente.

$2^{\circ}$ Vaso: colocar o vaso em local com pouquíssima ou nenhuma luminosidade e molhar diariamente. 


\section{CLONAGEM VEGETAL}

\section{Objetivos:}

Compreender reprodução assexuada das plantas.

\section{Habilidades da BNCC:}

(EM13CNT205) Utilizar noções de probabilidade e incerteza para interpretar previsões sobre atividades experimentais, fenômenos naturais e processos tecnológicos, reconhecendo os limites explicativos das ciências.

(EM13CNT301) Construir questões, elaborar hipóteses, previsões e estimativas, empregar instrumentos de medição e representar e interpretar modelos explicativos, dados e/ou resultados experimentais para construir, avaliar e justificar conclusões no enfrentamento de situações-problema sob uma perspectiva científica.
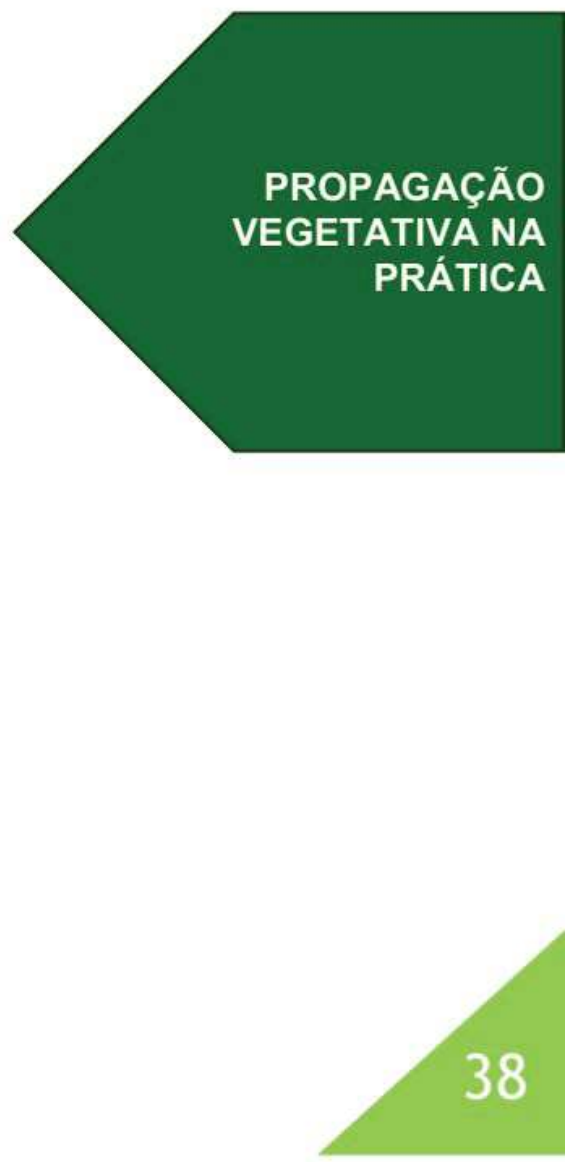
1. Nos vegetais superiores, de modo geral, a propagação ocorre pelas vias sexuada e assexuada. Como você diferencia estes dois tipos de propagação?

2. A clonagem está relacionada com qual dos processos de reprodução dos vegetais? Justifique sua resposta.

3. Para você, o que é um clone vegetal? Os clones vegetais possuem genes iguais ou diferentes? Justifique sua resposta:

4. Em algumas plantas, por exemplo, a bananeira, a propagação é feita por meio de mudas, retiradas de uma bananeira-mãe. Essa forma de propagação é considerada clonagem? Por que a bananeira precisa ser propagada por meio de mudas?

5. Ao longo dos tempos, o homem desenvolveu e vem fazendo uso de técnicas que lhe possibilitam o cultivo de vegetais de forma mais rápida. Dentre essas técnicas, é possível citar, a mergulhia, alporquia, enxertia e estaquia. Você conhece alguma delas, ou, já presenciou alguém em sua comunidade, fazendo uso de pedaços do caule, raízes ou folhas, no cultivo de plantas?

Os alunos poderão utilizar outras fontes de pesquisa para responder os questionamentos acima, após resolverem as questões, sugerimos que o professor faça uma breve explanação do tema com os alunos, sempre conduzindo a aula de forma que o aluno possa ter uma participação ativa.

Após contextualização do tema com os alunos, sugerimos que os mesmos sejam orientados na execução de uma atividade prática onde os mesmos deverão coletar "mudas" de 


\section{ADUBAÇÃO DO SOLO}

\section{Objetivos:}

Compreender relação entre a composição do solo e desenvolvimento das plantas.

\section{Habilidades da BNCC:}

(EM13CNT205) Utilizar noções de probabilidade e incerteza para interpretar previsões sobre atividades experimentais, fenômenos naturais e processos tecnológicos, reconhecendo os limites explicativos das ciências.

(EM13CNT301) Construir questões, elaborar hipóteses, previsões e estimativas, empregar instrumentos de medição e representar e interpretar modelos explicativos, dados e/ou resultados experimentais para construir, avaliar e justificar conclusões no enfrentamento de situações-problema sob uma perspectiva científica.
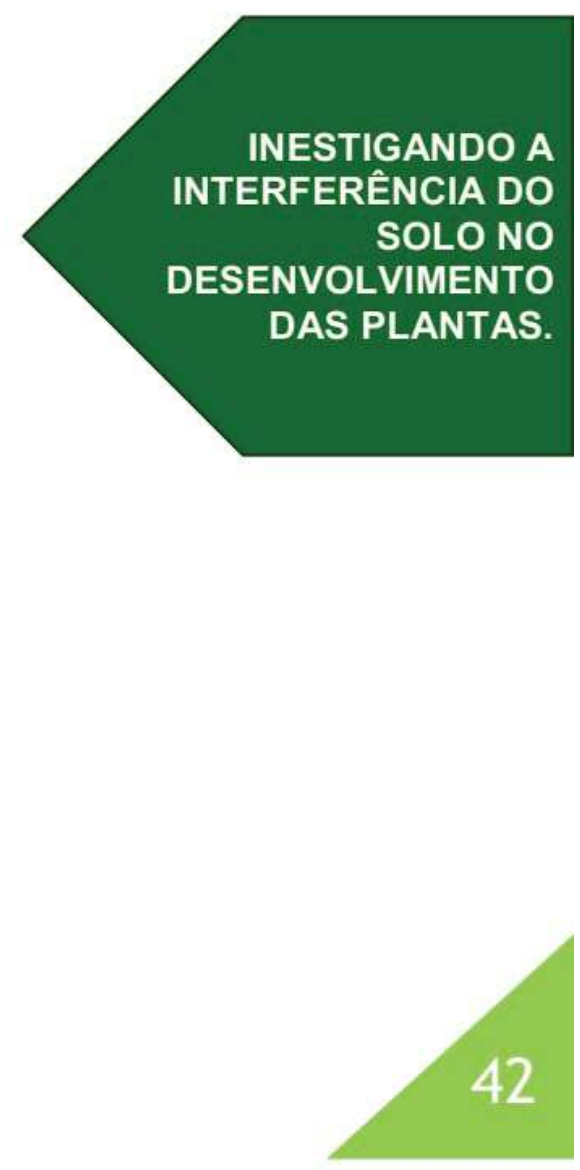


\section{Problematização}

O uso de esterco bovino para adubação do solo é muito comum no cultivo de hortas. Através deste experimento, pretende-se que os alunos possam analisar o efeito dos adubos orgânicos no desenvolvimento das plantas e desta forma compreenderem a importância da composição do solo e sua relação com a nutrição e desenvolvimento das plantas.

\section{Metodologia}

Nesta atividade os alunos poderão observar a relação entre a composição do solo e o desenvolvimento das plantas.

Ao realizar o cultivo na horta, os alunos deverão montar três pequenos canteiros, e nestes três canteiros, plantarem sementes de hortelã (ou outra planta que desejarem), eles irão numerar os canteiros, identificar a hortaliça e a data do plantio.

Esse experimento também poderá ser realizado utilizando garrafas pet ou vasos de plantas.

$\checkmark$ o canteiro 1 será o grupo de controle, esse canteiro será composto apenas por terra virgem.

$\checkmark$ No canteiro 2 será adicionado esterco bovino.

$\checkmark$ No canteiro 3 será adicionado composto orgânico produzido na composteira. 


\section{REFERÊNCIAS BIBLIOGRÁFICAS}

BARBOSA, N. V. S. Caderno 1 -A horta escolar dinamizando o currículo da escola. 3. ed. MEC: Brasília, 2009

BRASIL. Base Nacional Comum Curricular: Ensino Médio. Brasilia: MEC/Secretaria de Educação Básica, 2018.

BRASIL. Secretaria de Educação Fundamental. Parâmetros curriculares nacionais: meio ambiente, saúde. Brasília: MEC/SEF, p. 47-48, 1997.

CRIBB, S. L. S. P. Contribuições da educação ambiental e horta escolar na promoção de melhorias ao ensino, a saúde e ao ambiente. REMPEC- Ensino, Saúde e Ambiente, v. 3 n 1 p.4260. Abril, 2010.

EFFTING, T. R. Educação Ambiental nas Escolas Públicas: realidade e desafios. 2007. 90 f. Monografia (Pós Graduação em "Latu Sensu" Planejamento Para o Desenvolvimento Sustentável) - Centro de Ciências Agrárias, Universidade Estadual do Oeste, Marechal Cândido Rondon, 2007.

GONÇALVES, R. P. N.; GOI, M. E. J. A experimentação investigativa no ensino de ciências na educação básica. Revista Debates em Ensino de Química, v.4, n.2, p. 207-221, 2018.

IRALA, C. H. e FERNANDEZ, P. M. Manual para Escolas. A Escola promovendo hábitos alimentares saudáveis. HORTA. Brasília, 2001. 


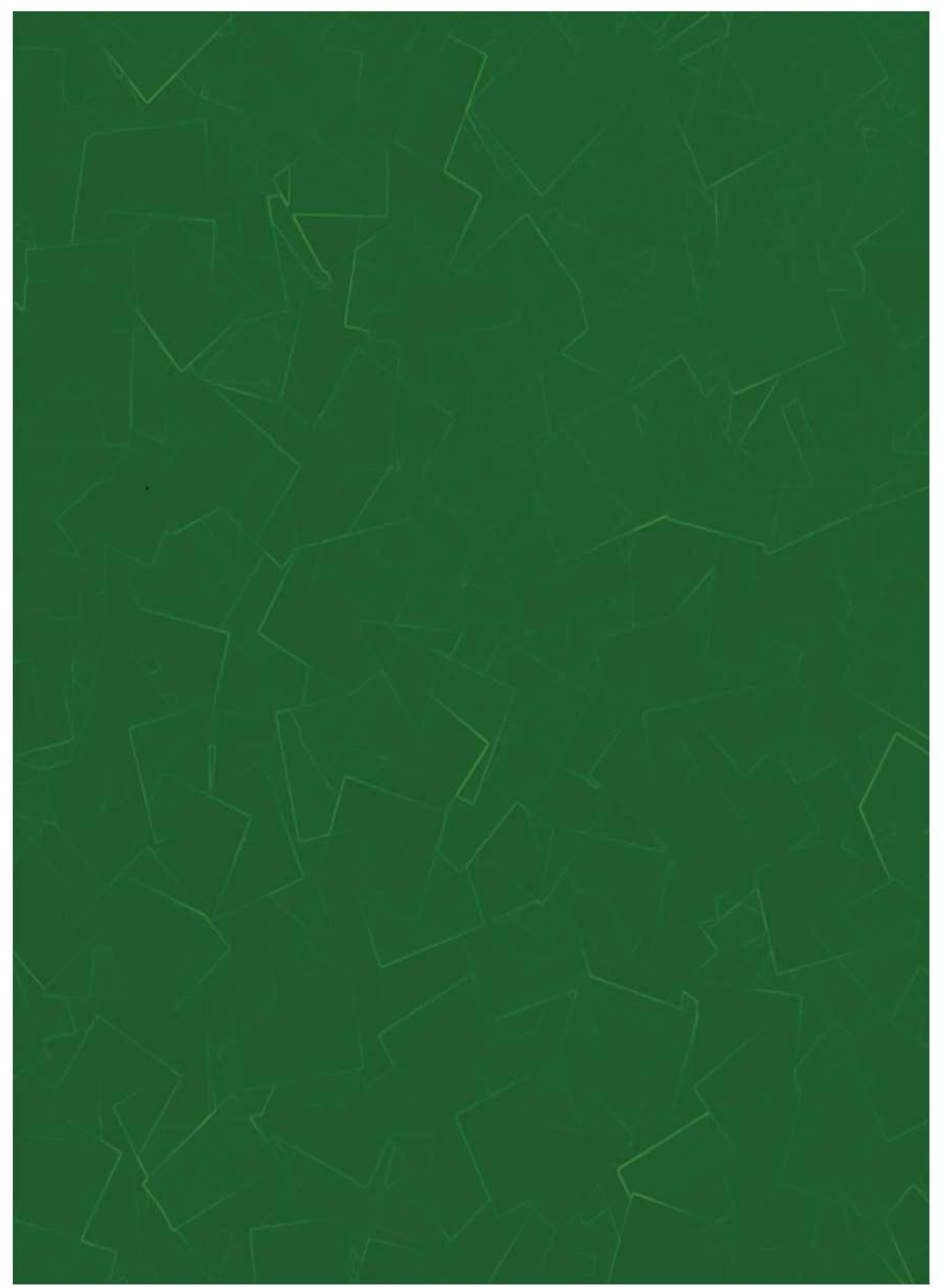

